\title{
WestVirginiaUniversity
}

THE RESEARCH REPOSITORY @ WVU

Graduate Theses, Dissertations, and Problem Reports

2017

\section{Presidential Executive Orders: The Bureaucracy, Congress, and the Courts}

Michael Edward Thunberg

Follow this and additional works at: https://researchrepository.wvu.edu/etd

\section{Recommended Citation}

Thunberg, Michael Edward, "Presidential Executive Orders: The Bureaucracy, Congress, and the Courts" (2017). Graduate Theses, Dissertations, and Problem Reports. 6808.

https://researchrepository.wvu.edu/etd/6808

This Dissertation is protected by copyright and/or related rights. It has been brought to you by the The Research Repository @ WVU with permission from the rights-holder(s). You are free to use this Dissertation in any way that is permitted by the copyright and related rights legislation that applies to your use. For other uses you must obtain permission from the rights-holder(s) directly, unless additional rights are indicated by a Creative Commons license in the record and/ or on the work itself. This Dissertation has been accepted for inclusion in WVU Graduate Theses, Dissertations, and Problem Reports collection by an authorized administrator of The Research Repository @ WVU.

For more information, please contact researchrepository@mail.wvu.edu. 
Presidential Executive Orders: The Bureaucracy, Congress, and the Courts

Michael Edward Thunberg

\author{
Dissertation submitted \\ to the Eberly College of Arts and Sciences \\ at West Virginia University
}

in partial fulfillment of the requirements for the degree of

Doctor of Philosophy in

Political Science

\author{
Jeff Worsham, Ph.D., Co-Chair \\ John Kilwein, Ph.D., Co-Chair \\ Matthew Jacobsmeier, Ph.D. \\ Dave Hauser, Ph.D. \\ Patrick Hickey, Ph.D. \\ Warren Eller, Ph.D.
}

Department of Political Science

\author{
Morgantown, West Virginia \\ 2017
}

Keywords: President, executive order, unilateral power, institutions, bureaucratic controls, U.S. Courts of Appeals

Copyright 2017: Michael Edward Thunberg 


\section{Abstract \\ Presidential Executive Orders: The Bureaucracy, Congress, and the Courts}

\section{Michael Edward Thunberg}

As the American president's use of executive orders continues gain prominence in the policy process, it is important that their use and limitations are fully understood. This research provides new insights to executive order use by addressing three questions. It asks how are executive orders used, when are executive orders used, and how does the judiciary respond to that use? I examine executive orders as bureaucratic controls, meant to alter agency behavior. I develop a framework based on the amount of discretion and authority the president grants executive agencies allowing for the identification four types of executive orders - routine, hortatory, coercive, and catalytic. Routine orders are used to accomplish common administrative tasks and have low grants of discretion and authority. Hortatory orders have high levels of discretion but low levels of authority and are used to investigate issue areas or coordinate information and advise the president. Coercive orders have high levels of authority and low levels of discretion and are used delegate specific authority and articulate specific tasks that need to be accomplished. Catalytic orders have high levels of discretion and authority, allowing the bureaucracy to both interpret and implement the executive order. When the president issues a specific type of executive order depends largely on the institutional context. There is a greater likelihood the president will issue a catalytic executive order in an attempt to circumvent Congress when he has low levels of partisan support. Finally, the U.S. Courts Appeals serves as a final check on the president's use of executive orders. While the courts rarely nullify an executive order, they do define the limits of their use by adding procedural limitations or constricting the reach an executive order has. These limitations develop a framework that presidents must work within when issuing future executive orders. This research advances the scholarly understanding of executive orders by examining them as bureaucratic controls that can be used in multiple ways. It moves away from dichotomous categorizations that limit explanatory value. Although executive orders are a strong presidential tool, this research shows there are checks on the exercise of that power by the judiciary. 
FOR MY FAMILY 


\section{BRIEF CONTENTS}

Chapter 1: Introduction..........................................................

Chapter 2: Delegating Discretion: Executive Orders and Bureaucratic Control.....10

Chapter 3: Understanding Executive Orders: Types, Time, and Trends...........31

Chapter 4: Presidential Policy Tools: The Strategic Use of Executive Orders........76

Chapter 5: Shaping Executive Orders in the U.S. Courts of Appeals..............108

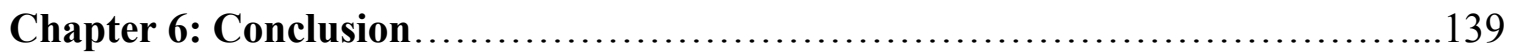




\section{CONTENTS}

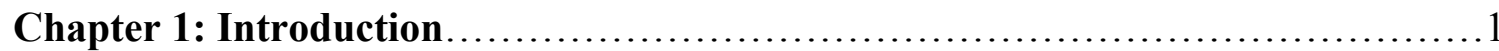

Overview and Roadmap...................................................4

Chapter 2: Delegating Discretion: Executive Orders and Bureaucratic Control.....10

Executive Order Use........................................................11

Executive Orders as Bureaucratic Controls......................................... 15

Mapping Executive Orders.................................................. 17

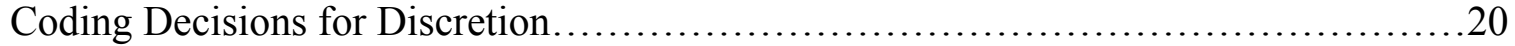

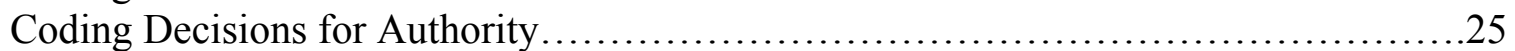

Coding Decisions for Amendments and Revocations................................28

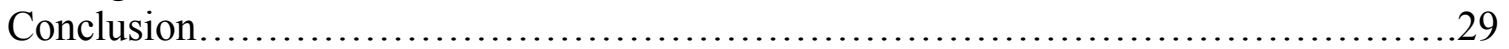

Chapter 3: Understanding Executive Orders: Types, Time, and Trends............31

Types of Executive Orders................................................. 32

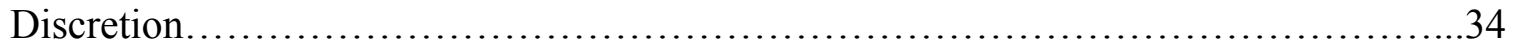

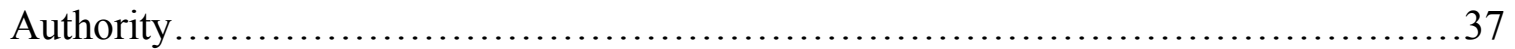

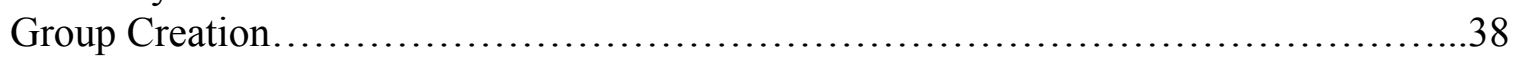

Advising and Reporting.................................................... 41

Routine - Hortatory - Coercive - Catalytic ................................... 45

Issuing Executive Orders........................................................ 54

Conclusion............................................................... 74

Chapter 4: Presidential Policy Tools: The Strategic Use of Executive Orders.......76

Executive Orders: The Evolution of Presidential Use.................................78

Executive Orders: The Right Tool for the Job.......................................82

The Strategic President Revisited............................................... 85

Testing for the New Strategic President: Research Design............................90

Results....................................................................... 92

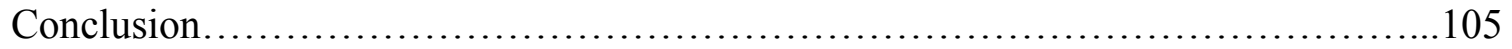

Chapter 5: Shaping Executive Orders in the U.S. Courts of Appeals..............108

A Unilateral Tool...............................................................110

Strong Signals: Challenging the President........................................ 111

Subtle Signals: Shaping The Presidency Through Nuanced Decisions..................115

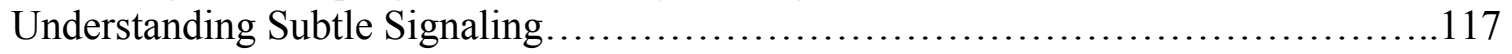

Data and Methods.......................................................... 120

Results and Analysis......................................................... 128

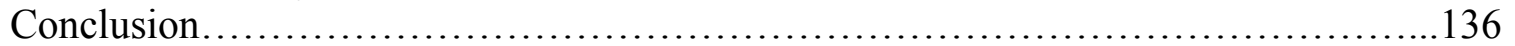


References.

\section{Tables}

Table 2.1: Types of Executive Orders, 1953-2012...............................18

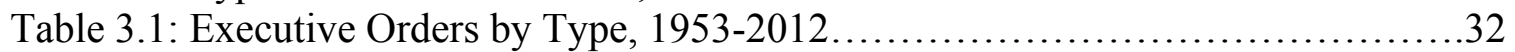

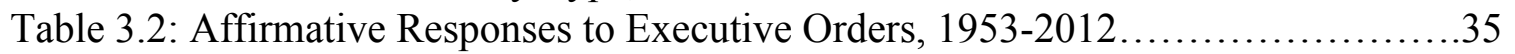

Table 3.3: Executive Orders Creating Groups, 1953-2012.......................... 36

Table 3.4: Executive Orders Requiring Advising or Reporting, 1953-2012 ............38

Table 3.5: Affirmative Responses to Executive Orders Creating Groups, 1953-2012 .....39

Table 3.6: Affirmative Responses to Executive Orders with Advising or Reporting

Requirements, 1953-2012 ...............................................42

Table 3.7: Affirmative Responses by Executive Order Type, 1953-2012..............47

Table 3.8: Executive Orders by President, 1953-2012 ............................57

Table 3.9: Types of Executive Orders by Party, 1953-2012........................58

Table 3.10: Types of Executive Orders Under Unified and Divided

Government, 1953-2012...........................................60

Table 4.1: Predicting Executive Order Types, 1953-2012.........................95

Table 4.2: Predicted Probabilities of Executive Order Type by Presidential Party, 1953-2012 ...........................................96

Table 4.3a: Republican Probabilities of Executive Order Type by House Support, 1953-2012........................................97

Table 4.3b: Democrat Probabilities of Executive Order Type by House Support, 1953-2012 .........................................97

Table 4.4a: Republican Probabilities of Executive Order Type by Senate Support, 1953-2012........................................99

Table 4.4b: Democrat Probabilities of Executive Order Type by Senate Support, 1953-2012...........................................99

Table 4.5a: Republican Probabilities of Executive Order Type by Approval Rating, 1953-2012 ...................................... 101

Table 4.5b: Democrat Probabilities of Executive Order Type by

Approval Rating, 1953-2012 ........................................ 101

Table 4.6a: Republican Probabilities by Policy Type, 1953-2012 ................... 103

Table 4.6b: Democrat Probabilities by Policy Type, 1953-2012.....................103

Table 4.7a: Republican Probabilities by War, 1953-2012 .......................... 105

Table 4.7b: Democrat Probabilities by War, 1953-2012 .........................105

Table 5.1: Upholding Executive Orders in the U.S. Courts of Appeals, 1943-2012 .....131

\section{Figures}

Figure 3.1: Executive Order Types Across Time, 1953-2012......................56

Figure 3.2: Types of Executive Orders Issued by

House Partisan Support, 1953-2012....................................64 
Figure 3.3: Types of Executive Orders Issued by

Senate Partisan Support, 1953-2012 ..........................................65

Figure 3.4: Types of Executive Orders Issued by

House Ideological Distance, 1953-2012.....................................69

Figure 3.5: Types of Executive Orders Issued by

Senate Ideological Distance, 1953-2012 .................................... 70

Figure 3.6: Types of Executive Orders Issued by

Presidential Approval Rating, 1953-2012 .....................................72

Figure 5.1: Executive Orders in the U.S. Courts of Appeals, 1943-2013 ................129

Figure 5.2: Types of Executive Order Constraint in the

U.S. Courts of Appeals Over Time, 1943-2013 ...............................129

Figure 5.3: Hypothesis Testing: When Constraint Occurs in the

U.S. Courts of Appeals, 1943-2013 .....................................132

Figure 5.4: Predicted Probabilities of Constraint:

Republican Partisan and Panel Effects, 1943-2013............................133

Figure 5.5: Predicted Probabilities of Constraint: Ideological Distance, 1943-2013.....135

Figure 6.1: Types of Executive Orders, 1953-2012 ...............................141 
Chapter 1

Introduction 
We are not just going to be waiting for legislation in order to make sure that we're providing Americans the kind of help that they need. I've got a pen, and I've got a phone. And I can use that pen to sign executive orders and take executive actions and administrative actions that move the ball forward in helping to make sure our kids are getting the best education possible, making sure that our businesses are getting the kind of support and help they need to grow and advance, to make sure that people are getting the skills that they need to get those jobs that our businesses are creating...

-President Barack Obama 2014

Presidents regularly face challenges from Congress when attempting to shape policy, pushing presidents to use unilateral action to accomplish their goals. President Obama's claim to act independently of Congress is not an uncharacteristic statement for Obama, or any other president for that matter. But it is an important one because it draws attention to several important aspects of our political system. Importantly, this statement identifies the tension that commonly exists between the competing interests of the White House and Congress. Presidents have policy agendas and limited time to accomplish their goals. At times, the branches of government are at odds with one another making it difficult to pass legislation. When this occurs, presidents turn to the institutional tools of the presidency to accomplish their agenda.

The president has a wide range of tools that can be used to achieve their policy goals including proclamations (Rottinghaus \& Maier 2007), memoranda (Lowande 2014), signing statements (Ostrander \& Sievert 2012), the mobilization of the public (Kernell 2006), and executive orders (Cooper 2014). However, none are more controversial than executive orders. They allow the president to act without the consent of Congress and enact a resolution that carries the full weight of law once the president's signature is affixed. According to Cooper $(2014,21)$ executive orders are:

...directives issued by the president to officers of the executive branch, requiring them to take an action, stop a certain type of activity, alter policy, change management practices, or accept a delegation or authority under which they will henceforth be responsible for the implementation of law. 
The use of executive orders raises concerns by Democrats and Republicans because it allows the president to circumvent the traditional policy process and minimize the voice of Congress. While some executive orders are used for mundane purposes, they are increasingly used to accomplish more significant policy goals (Mayer 2001; Howell 2003; Warber 2006). President Obama identified several policy areas in the statement that opened this chapter, including education, the economy, and jobs. These are not trivial policy areas but show the range of issues presidents attempt to affect unilaterally.

President Obama is not the only president to use executive orders or to use them in pursuit of achieving significant policy goals. All presidents since George Washington have used executive orders (Dodds 2013). Franklin Roosevelt marked the peak of presidential action, including the use of executive orders. He issued more executive orders than any president before him or any of those to take office after him. FDR used executive orders to help construct the administrative state and many of the responsibilities of the president were subsumed by the growing bureaucracy, reducing the number of executive orders a president needed to issue. Despite the steady decline of executive orders since FDR, it has become a fundamental tool in any administration's policy arsenal, sparking scholarly attention. It is only within the last two decades that scholarship on the president's use of executive orders has started to flourish.

The growing attention to the presidential use of executive orders is critically important because of the role executive orders play in our policy process. Researchers have advanced our understanding of when presidents use this tool, however, there are significant shortcomings. This dissertation builds upon and fills the gaps left by previous works. It addresses underdeveloped areas of executive order research by asking three simple questions about executive order use how are executive orders used, when are executive orders used, how does the judiciary respond 
to their use. While research has addressed when executive orders are used, how they are used and the judiciary's response requires more investigation to the mechanisms by which executive orders affect policy.

The dissertation proceeds as follows. The remainder of the introduction will provide a brief outline of the argument presented in the dissertation, an overview of each chapter, and the major contributions of the work. Chapter 2 will review the extant literature, identify gaps, and develop a new framework to analyze executive orders. Chapter 3 provides a descriptive analysis of the executive order data and identifies trends in the data to provide the reader with a better understanding of the framework used. Chapter 4 attempts to unify competing theories of executive order use by providing a more rigorous statistical analysis of the data. Chapter 5 introduces a second new dataset and examines how the U.S. Courts of Appeals treats cases involving an executive order. Finally, Chapter 6 summarizes the findings, examines the work's contributions, and identifies avenues for future research.

\section{Overview and Roadmap}

Most research assumes when the president issues an executive order, the policy objectives contained within that order are carried out because the president has delivered a concise policy directive. This leads researchers to focus on two questions - what are executive orders used for and how do the institutional relationships between the executive and legislative branches affect executive order use? Answering these questions has greatly advanced our understanding and identified that executive orders are used for significant or non-significant purposes (Mayer 2001; Howell 2003) and policy or non-policy purposes (Warber 2006). These dichotomies are used to determine when executive orders are issued with the most common variable of interest being unified or divided government. While there are results to support each 
claim, that executive orders are used more often under unified or more often under divided government, the most commonly accepted explanation is that they are used under divided government to circumvent a hostile Congress, echoing the sentiments of President Obama at the beginning of the chapter. It is clear form Obama's statement that if Congress refuses to work with the president, there are alternatives the president can turn to in order to accomplish his agenda.

However, a disconnect exists between our understanding of why and when executive orders are used, and how they are actually used. Previous research jumped the gun by asking why and when they are used before asking how they are used. Executive order research judges an orders importance in relation to actors external to the president - Congress, the courts, the media. The dependence on outside actors to judge an independent tool of the president limits the explanatory value of analysis because the tool can only be judged by how others react. While presidents might have some a priori understanding of how outside actors will react, it cannot be known until the executive order is issued. Therefore, under the current method of analyzing executive orders, there is no way for an administration to judge the utility of an executive order until after it is issued and a response occurs.

Chapter 2 of this dissertation provides a major theoretical contribution by taking a step back from the current research program on executive orders to ask how they are used. In this chapter a new framework of analysis is developed that examines executive orders through the lens of bureaucracy. Drawing from common definitions of executive orders (Cooper 2014) and integrating work from the field of public policy that examines bureaucratic controls (Gormley 1989), the new framework presented here identifies the amount of authority and discretion executive orders grant the bureaucracy in pursuit of presidential policy preferences. 
Data are collected from the text of 3,199 executive orders and analyzed according systematic standards to determine the amount of authority and discretion the president grants bureaucratic agents in an executive order. There are eight yes/no questions used to measure each dimension of authority and discretion. The decision logic, coding criteria, and examples for these sixteen questions are laid out in Chapter 2.

Using the standards established in this framework, four mutually exclusive categories are developed that determine how executive orders are used - routine, coercive, hortatory, and catalytic. Routine orders have low levels of discretion and authority. They are used for common administrative tasks (closing federal offices for Christmas) or symbolic reasons (designing a medal). Coercive orders grant high authority but little discretion. They are commands from the president to carry out specific tasks. Hortatory orders have high grants of discretion and low grants of authority. These are used to allow agencies to investigate policy areas and report to the president, but do not allow agencies to act upon their recommendations. Finally, catalytic orders have high grants of authority and discretion. They provide general guidance to agencies but allow the executive agents to determine the direction of policy and act upon it.

Examining executive orders through this framework provides two significant contributions to the discipline. First, it creates an independent measure of executive orders that does not require outside actors to react before the order can be measured. Second, it creates four types of executive orders that provides additional nuance and identifies the mechanisms that occur when this tool is used. This moves beyond dichotomous categorizations such as significant or not and policy relevant or not to create a more complete picture of executive order use.

Chapter 3 provides a descriptive examination of the data. It analyzes the response rates of the 16 yes/no questions. Trends within executive orders are identified to determine when 
affirmative responses to questions commonly appear in the same executive order. The review of the data then turns to the different types of executive orders and the makeup of affirmative responses found in each. Each executive order is scored based on the affirmative responses to the sixteen questions developed. Based on the score each order is assigned to one of the four types of executive orders. The contents of each type of order are analyzed and found to be consistent with their purpose. A descriptive analysis is then conducted to examine trends of different types of executive orders across time, administrations, unified and divided government, and popularity.

After developing the mechanisms for how executive orders in Chapter 2 and providing a descriptive analysis in Chapter 3, Chapter 4 explores the discipline's more common questions; when are executive orders used. With multiple categories of interest, competing theories of executive order use are applied in an attempt to unify conflicting theories under the newly developed framework. Some suggest presidents use executive orders to bolster legislation under Congressional support while others argue the tool is used to circumvent Congress when support is low. The argument proposed in this research is that presidents issue more specific orders (coercive) when they have the support of Congress and as presidents lose support, they issue orders that push the policy process to the bureaucracy (catalytic), allowing executive agents to act with greater discretion and authority. The main finding is that presidents issue more catalytic orders when they face low levels of support in Congress. While the initial results fail to unify competing theories, they do complement and extend arguments that suggest executive orders are used for more significant policy purposes that circumvent a hostile Congress.

Chapter 4 looks at the commonly studied institutional relationship between the president and Congress to determine the effects of that relationship on executive order issuance. Chapter 5 examines the understudied institutional relationship between the president and the federal 
judiciary. There is limited systematic analysis of how the judiciary treats cases involving executive orders. The courts play an essential role in our political system, but when it comes to executive order research the focus remains on executive-legislative relations. A step to fill this gap is taken here by focusing on the U.S. Courts of Appeals. A new dataset of 371 written U.S. Courts of Appeals opinions is collected and analyzed to determine how the intermediate courts treat executive order use. Text analysis is used again to move away from binary coding of judicial outcomes - uphold or overturn. Instead the courts have a third option that allows circuits to shape the contours of executive order use and send subtle signals to the executive, delineating the boundaries of future executive order use. This is an important component of the dissertation because it extends the discipline's understanding of the limitations of executive order use and the types of tools available to circuit court judges.

This dissertation provides both theoretical and practical contributions to the discipline. While these contributions are explored in greater detail in Chapter 6, there are several major contributions that are worth noting. First, it extends our understanding of presidential powers. It reconceptualizes how executive orders are used and while it fails to unify competing theories of executive order use, it bolsters the most commonly accepted explanation that presidents use this tool to circumvent Congress. Importantly, this research illuminates how that is done.

Second, this framework allows executive orders to be analyzed, and their purpose judged, independently of the other branches of government, a critical shortcoming in previous executive order research. This is not only a theoretical advancement, but also a practical one. Administrations can now construct executive orders according to this framework and better understand how the contents of an order effect bureaucratic responses. 
Finally, it addresses criticisms that executive orders are a draconian tool of the president that cannot be contained. This research shows that is not the case and the U.S. Courts of Appeals play a significant role in shaping executive order use. In many cases, the circuit court's role goes over looked because it is not as visible as a direct challenge to the president. As a theoretical contribution, this portion of the research shows the limitations on executive orders, the important role of the judiciary, and stimulates discussion across the subfields executive and judicial politics. There are also practical applications to these findings that mirror the theoretical ones. It shows the limitations and weaknesses of executive orders administrations must be aware of when crafting new orders. Most importantly, it shows the institutional structures of government operate the way they were intended and the judiciary serves as a final backstop to the exercise of presidential power. 
Chapter 2

Delegating Discretion: Executive Orders and Bureaucratic Control 
The presidency is an institution that provides the incumbent multiple tools to pursue his or her policy agenda (Cooper 2014; Howell 2013). A prominent tool that can achieve significant policy outcomes but is increasingly scrutinized is the executive order (Mayer 1999). Executive orders "....are directives issued by the president to officers of the executive branch, requiring them to take an action, stop a certain type of activity, alter policy, change management practices, or accept a delegation or authority under which they will henceforth be responsible for the implementation of law" (Cooper 2014,21). With the absolute number of executive orders on the decline, research focuses on understanding when the president issues significant orders based on the institutional constraints he faces-partisan support, ideological differences with Congress, and approval rating (Mayer 2001; Howell 2003; 2005; Warber 2006; Chiou \& Rothnberg 2014). These studies provide a better understanding of when the president uses this tool, but miss an important component of executive order use — how they are used. This study addresses how executive orders are used before providing an explanation for when they are used. This study proceeds in three parts. First, it identifies an important gap in our understanding of executive orders and develops a theoretical framework to examine executive orders as bureaucratic controls. Next, it develops the criteria for coding the 3,199 executive orders from $1953-2012$ into mutually exclusive categories — routine, hortatory, coercive, and catalytic. Finally, it examines when different types of executive orders are issued.

\section{Executive Order Use}

Presidents enter office with a clear agenda but can struggle to achieve their goals through the traditional legislative process. Faced with uncertainty about the legislative process and a desire to implement good policy that will secure their legacy (Light 1999,63), presidents can centralize the legislative process within the Executive Office of the President (EOP) (Rudalevige 
2002). Centralization can include drafting legislative proposals within the EOP to directly mirror presidential preferences or advancing policy goals directly through the administration (Nathan 1983). Presidents regularly turn to executive orders (EOs) because they carry the full weight of law and do not require congressional approval (Cooper 2014; Dodds 2013; Fleishman \& Aufses 1976,5; Morgan 1970,4). Executive orders allow the president to take advantage of the role of chief administrator, directing bureaucratic agents to implement policy objectives, often under the cover of bureaucratic management (Nathan 1983; Durant \& Warber 2001).

Despite a growing research program examining the bureaucracy's role as a key component to the creation of executive orders (Rudalevige 2015), research commonly overlooks the interaction of agencies and executive orders. Most research on executive orders assume the president is directing executive agents to act, but do not ask how. They concentrate on presidential-congressional relations to determine when the president is likely to issue an executive order. Early studies neglected the content and purpose of executive orders entirely, using simple counts to determine if more orders were issued during times of unified or divided government (Krause \& Cohen 1997; Deering \& Maltzman 1999). Acknowledging the limitations of using a simple count, several studies add additional nuance in an attempt to determine the ends served by executive orders (Mayer 2001; Howell 2003; Fine \& Warber 2012). However, these studies produce conflicting results depending on the method used to code executive orders. In a fashion similar to Mayhew's (2005) categorization of significant legislation, Mayer $(1999 ; 2001)$ identified significant and non-significant executive orders based on media and academia attention. Howell (2003) developed significant and non-significant categories as well, but determined their importance primarily on their appearance in the appendix of the Congressional Record or their mention in federal court opinions. Extending that work, Howell 
(2005) developed a measure of significance by focusing on mentions in the New York Times.

The internal validity is apparent when using a single source to code significance, however there are limitations and biases associated with using a single print news outlet leading Chiou \& Rothenberg (2014) to employ a scaling approach to significance based on responses from nineteen sources. Using alternative specifications for significant executive orders leads to mixed results, making it difficult to determine if arguments of issuance under unified (Gleiber \& Shull 1992; Krause \& Cohen 1997) or divided government (Deering \& Maltzman 1999) are correct. Warber (2006) moves beyond the categories of significant and non-significant, focusing on the policy content of executive orders to add a more nuanced understanding. While he initially develops three ideal categories—symbolic, routine, policy—Fine \&Warber (2012) collapse the categories to policy and non-policy orders. Using these categories Fine \& Warber (2012) find support for Deering \& Maltzman's (1999) strategic model, where the president issues policy executive orders to circumvent an ideologically opposed Congress.

These studies move toward understanding how executive orders are used but suffer from similar limitations. First, while they begin to examine the content of executive orders, categories are determined by their relation to the legislative branch or media attention (see Rudalevige 2015). These measures of significance do not provide an independent method to determine how the president is using this tool to direct bureaucratic action. Before it is understood when this tool is used, it has to be understood how it is used as an independent tool. Second, these measures generally dichotomize the use of executive orders to significant or not, policy related or not. ${ }^{1}$ This dichotomy creates only one category of interest and suggests presidents are only issuing

\footnotetext{
${ }^{1}$ Chiou \& Rothenberg (2014) create a scale of significance to provide additional nuance but their measure still suffers from similar limitations of dichotomizing orders leaving only one category of interest.
} 
executive orders to a significant extent during times of unified or divided government, but not both.

To overcome this limitation in the current literature, executive orders must be understood as an independent tool available to the president to direct bureaucratic action. This can be done by examining executive orders through the lens of bureaucratic controls (Gormley 1989). In a response to the growing bureaucratic apparatus following the New Deal, Gormley categorized bureaucratic controls according to the amount of authority and discretion agencies are granted when responding to a principal's requests. He identified three ideal categories bureaucratic controls fall under - coercive, hortatory, and catalytic. This categorization provides a unique lens to examine ways to influence bureaucratic action. However, Gormley argues multiple tools are available when attempting to direct bureaucratic outcomes. Executive orders are only one tool and are considered coercive by Gormley, so the application of his framework requires the inclusion of additional components.

When examining executive orders as a single tool, Gormley's (1989) coding of all executive orders as coercive aligns with general definitions of an executive order (Cooper 2014). Executive orders are coercive commands because they are backed by the authority of the president. Assuming all executive orders have a basic coercive function and agencies feel pressure to respond to an explicit directive from the president, it is possible to reapply Gormley's bureaucratic controls within the confines of executive orders to differentiate types of orders. Not all executive orders are equal. Some limit agency actions (coercive), some provide a good deal of discretion (hortatory), and some land somewhere between (catalytic). The following section lays out the adaptations necessary to apply of Gormley's framework to the confines of executive orders. 


\section{Executive Orders as Bureaucratic Controls}

Executive orders are a single presidential tool but closer analysis shows there are multiple types used for different purposes. There is no one way to direct bureaucratic action and presidents can craft executive orders that provide more explicit directives or grant additional discretion that allow agencies to act more freely. Applying Gormley's framework of coercive, hortatory, and catalytic bureaucratic controls to executive orders allows them to be examined independent of external actors.

Coercive controls require bureaucracy to act in a specific fashion. Gormley argues coercive controls are considered "muscles" because they are authoritative and clearly specify procedures and goals for agencies to follow (see Huber and Shipan's (2002) discussion of legislative efforts to direct bureaucracy for a similar line of argument). Adapting coercive controls to executive orders requires an additional component. Gormley's argument allows various actors, not just the president, to apply pressure and get agencies to act in accordance with their desired outcomes. Executive orders are different because once issued represent a single directive coming from a single actor, the president. ${ }^{2}$ All executive orders carry a coercive component because they are directives from the president and carry the full weight of law. However, not all executive orders provide bureaucratic agents the necessary authority to carry out the president's will. Coercive executive orders differ from Gormley's traditional definition of coercive because it is not the president exerting authority to enforce compliance, that authority is assumed to exist by virtue of the executive order. The coercive nature is exercised by agents because the president delegated authority to implement the order. The Secretary of Treasury was granted coercive power when President George W. Bush issued Executive Order 13290 allowing

\footnotetext{
${ }^{2}$ See Rudalevige (2015) for arguments about drafting executive orders and agency influence.
} 
the Secretary to perform all presidential functions when blocking Iraqi property. The president provided specific authority within a narrow issue area.

Hortatory controls are a middle category for Gormley, with intermediate levels of authority and discretion. Developing hortatory controls as a category for executive orders requires relaxing Gormley's definition. His definition suggests controls can lean toward increased authority or discretion but ultimately fall on the middle of a continuum between coercive and catalytic. In an effort to develop mutually exclusive categories, hortatory executive orders focus on increased levels of discretion without the authority necessary to carry out the order. These are most commonly investigatory orders that focus agency attention and allow the president utilize agency expertise for information on substantive policy issues. For instance, President Obama set up the National Commission on Fiscal Responsibility and Reform by issuing Executive Order 13531 which required agencies to investigate the best methods to balance the budget and stabilized the debt-to-GDP ratio. The broadly defined mission granted agencies the discretion to investigate economic policy and develop recommendations, but were granted no authority to carry out those recommendations.

Catalytic controls are considered prayers because they direct agency attention to an issue but do not specify a mandatory solution, providing agencies high levels of discretion to determine how that goal is met (Gormley,12-13). Adapting catalytic controls to executive order use also requires an additional component. It is not enough for executive agents to have the discretion to interpret an executive order, they must also be granted the authority to implement and enforce those choices. Catalytic executive orders require a high degree of both discretion and authority. In an effort to make the government more environmentally friendly President Clinton 
issued Executive Order 13148, granting agencies the ability to develop and implement policies that met both specific and broad sustainability goals.

A final extension of Gormley's framework is needed. Some executive orders are used for routine or symbolic purposes and have minimal substantive impact on policy (Warber 2006). For this reason, a routine category of executive orders is included.

\section{Mapping Executive Orders}

The application of Gormley's framework provides answers to questions common in studies on executive orders. Specifically, it moves past counting sheer numbers, or using indirect measures of importance to isolate executive orders as an independent tool of the president. Executive order data for this project comes from the American Presidency Project where I employ a content analysis of 3,199 executive orders issued from Presidents Eisenhower's (1953) inauguration through Obama's first term (2012). I started with Eisenhower instead of FDR for two reasons. First, excluding FDR and Truman is consistent with the literature (Krause \& Cohen 1997; Deering \& Maltzman 1999; Howell 2003). Second, FDR was instrumental in expanding the office of the president and used executive orders to achieve that goal, with FDR issuing 3,734 orders and Truman issuing 899. Presidents since have built upon that legacy but none have used executive orders in such high volume, so FDR and Truman are considered by most to be outliers.

Developing a systematic schema for coding executive orders that allows for easy replication is one of the most difficult tasks the researcher examining this unilateral tool faces. Getting leverage on executive orders and their role in the political system requires analyzing and categorizing orders based on their content. This is a difficult and subjective process (Mayer 2001,85; Warber 2006,140) that has led to as many methods as there are studies on executive orders. Cognizant of this challenge, the systematic development of questions is used to provide 
consistency across time and administrations when coding executive orders as coercive, hortatory, catalytic, and routine based on their interaction with bureaucratic agencies. Sixteen yes or no questions measure the amount of discretion and authority agencies are granted in the executive order. Although the concepts of discretion and authority are not mutually exclusive, I separate them conceptually to better understand how executive orders are used. Each question answered affirmatively receives one point. The points are then added up for discretion and authority and the executive order is placed in the appropriate category according to its value (see Table 2.1). There are concerns with applying an additive scale especially one with varying cut points. An order scoring 0 to 2 is placed in the low category for discretion or authority, respectively. Orders scoring a 3 or above are placed in the high category for discretion or authority, respectively.

Table 2.1: Types of Executive Orders, 1953-2012

DISCRETION

\begin{tabular}{l|c|c} 
& Low (0-2) & High (3+) \\
\hline Low $(0-2)$ & Routine & Hortatory \\
\hline High $(3+)$ & Coercive & Catalytic
\end{tabular}

The additive scale raises concern because questions are intended to tap into individual components of authority and discretion. Applying an additive scale implies the weight of each response is equal, with more affirmative answers meaning greater grants of authority or discretion. In a practical sense, affirmative answers to some questions provide more authority or discretion than others. In a theoretical sense, treating them as equal does not harm the analysis. Isolating individual components of an executive order is not the end goal, it is the means to achieve the categorization of orders. Questions are meant to approximate the level of authority 
and discretion bureaucratic agents receive, providing new insights into how this tool is used. Affirmative responses to individual questions are maintained for future analysis into the various components. Additionally, the individual components are explored in greater depth in the next chapter.

The cut points chosen to determine an executive order's category also presents concern because they are unbalanced. Low levels range from 0 to 2 and high categories range from 3 to 8 . Although unbalanced, point divisions do not present concerns for the analysis. The low point values are set to account for routine and symbolic matters which do require a minimum level of authority or discretion to implement but do not rise to a significant level of importance. Despite their routine or symbolic nature, they still must be accounted for independently in the analysis. Although affirmative responses totaling 3 to 8 leaves room for variation, it is important variation that does not substantively alter which category an executive order is placed in. Questions could be collapsed to make point categories more "balanced." However, there is important nuance captured in the current question set which can help future researchers further dissect the content of executive orders. Collapsing the categories at this early stage of the research process limits the contribution to understanding executive order use. With these potential limitations in mind, the following questions are used to code executive orders: 


\section{Questions of Discretion}

1. Does the executive order create a committee/task force/board with a policy focus?

2. Does the executive order create a committee/task force/board with a coordination focus?

3. Does the executive order contain substantive goals?

4. Does the executive order contain a new definition not grounded in statute?

5 . Does the executive order allow agencies to control information?

6. Does the executive order grant implementation power?

7. Does the executive order grant rule-making power?

8. Does the executive order grant agenda setting power?

Questions of Authority

1. Does the president cite a specific statute in the vesting clause?

2. Does the executive order delegate statutory authority to an agent?

3. Does the executive order contain a definition grounded in statute?

4. Does the executive order articulate specific procedures to be followed?

5. Does the executive order grant agents negative powers?

6. Does the executive order include a general reporting and/or advising requirement?

7. Does the executive order include presidential reporting and/or advising requirement?

8. Does the executive order require the staffing of non-federal actors?

\section{Coding Decisions for Discretion}

1. Policy Group: The creation of a policy group is an effective way for the president to focus the attention of bureaucratic actors toward a single issue. These groups come in many forms including committees, task forces, and boards, all of which draw from the expertise of multiple agencies. While the group might be limited to a single issue, the group has the capability of investigating the issue any way they see prudent. The group has the ability to pursue, accept, reject, or discard information they believe will create the best policy. Language in executive orders for the creation of a group is explicit and designates key actors that will make up the group. The order will also lay out the functions the group will carry out. To gain a better understanding of how executive orders are used, policy and coordination groups are coded independently and treated as mutually exclusive. Unless an executive order creates multiple groups, the intent of the group as expressed in its functions is used to code the 
group type. This is an important caveat to note because policy groups can have a coordination function. However, policy groups have the discretion to examine policy issues while coordination groups serve an independent purpose. President Reagan established the National Communications System, a group of principals designated the function of advising the president, exercising telecommunications functions, and planning for emergency preparedness.

2. Coordination Group: The creation of a coordination group is a way for the president to ensure agencies and actors are acting uniformly or are informed of others actions and information. The purpose of these groups is to act as a clearing house for agencies and actors to disseminate and collect information from across the federal government on a specific policy issue. The group does not have the ability to make suggestions about the policy, only to provide information to agencies so the federal government acts in a unified fashion. Coordination groups are coded as a grant in discretion because it allows the group set up the infrastructure it believes best accomplishes the coordination of agencies and actors. Language used to code coordination groups is similar to policy groups but focuses on functions that articulate coordination as its main purpose. President W. Bush used this type of group when he issued Executive Order 13128: $21^{\text {st }}$ Century Workforce Initiative. Section 1 of this executive order established the Office of the $21{ }^{\text {st }}$ Century Workforce with Section 1(b) delineating its responsibilities. The office's key responsibility was to “...gather and disseminate information relating to workforce issues..." This office served as a clearinghouse of information and worked to coordinate information among disparate agencies. 
3. Substantive Goals: Substantive goals come in the form of a mission or policy statement. They provide general direction to agencies and actors. The language used is general and focuses attention on policy issues or outcomes but does not provide specific details or steps that must be taken to achieve the president's desired outcome. President Clinton stated substantive goals in Executive Order 13011: Federal Information Technology. Here, he required that “...executive agencies shall... establish an interagency support structure that builds on existing successful interagency efforts..." Agencies and actors have an increased amount of discretion because the president's broad articulation of objectives allows actors to interpret those goals. Each agency will interpret the goals through the lens of its agency's mission and pursue policies that reflect both the president's and agency's goals.

4. New Definition: The president can use executive orders to define terms that agencies will apply. The language is clear, stating term $\mathrm{X}$ is defined as $\mathrm{Y}$. There are two types of definitions the president can include in an executive order, a new or statutory definition. The new definition is created by the president for the purposes of the executive order and is not grounded in a statute. It provides agencies and actors increased discretion because it is limited to the application of the executive order it is stated in. Agencies have greater flexibility in interpreting the president's definition to match presidential goals and in determining if the use of the definition is applicable.

5. Information: A key purpose of executive orders is to provide the president with information and ensure agencies are informed about the president's policies. Information components of an executive order can take two forms, as either input or an output. When the information function takes the form or an input, it requires actors to collect information on an issue area to 
inform policy making. When the information function takes the form of an output, it requires actors to disseminate and coordinate information. In both cases, it grants agents control over information. The language used by the president in assigning these tasks focuses on gathering, collecting, investigating, and coordinating information. For instance, in President W. Bush's Executive Order 13287: Preserve America, he requires agencies to prepare an assessment of historic properties and use any existing information gathering and reporting systems to do so. The ability to control information is considered an increase in discretion because it allows actors to independently seek out information and determine what information is relevant to inform policy.

6. Implementation: Implementation is the most important function executive agencies have (Meier 1987) and explicitly stating that in the text of an executive order grants important discretionary power for two reasons. First, it allows executive agents to decide how to execute the president's will and develop procedures best suited to their organization. This means multiple agencies might interpret an executive order differently and develop different procedures to implement the order. Similarly, the implementation process provides low level bureaucrats increased discretion to interpret and carry out the executive order (Lipskey 1980). Finally, when the president requires agencies to implement an executive order, that is different than calling for the development of rules and regulations. Although calling for the promulgation of rules and regulations is a way to track agency response (Kennedy 2015), implementation does not require an agency to produce explicit rules. Informal procedures can be equally as effective in carrying out the president's will. President Obama delegated implementation power to the Deputy Director of Management of the Office of Management and Budget in Executive Order 13571: Streamlining Service Delivery and Improving 
Customer Service. It allowed the deputy to develop guidelines and requirements. The language used to determine if the president is requiring actors to implement the executive order will clearly state actors have the ability to act.

7. Rule-Making: The president can require agencies to develop rules and regulations to carry out the policies articulated in the executive order. This is different than implementation because agencies follow different procedures for developing a formal regulation. Rule-making is coded as an increase in discretion because it allows agencies to develop rules that meets the president's and agency's goals. The language used to determine if the president is granting rule-making power is clear and calls for the promulgation or implementation of rules and regulations. For instance, Executive Order 13310: Blocking Property of the Government of Burma and Prohibiting Certain Transactions clearly states "The Secretary of the Treasury... is hereby authorized to take such actions, including the promulgation of rules and regulations..."

8. Agenda Setting: Individuals and groups able to independently set the agenda are viewed as powerful actors with a great deal of discretion (see Majone 2006). Even when the president directs attention toward a specific policy area, the ability to define the agenda allows agents to focus attention on problems falling within that policy area (Walker 1977) and cultivate new ideas (Rochefort \& Cobb 1994). The primary language used to determine and code if the president is granting agenda setting power is sometimes explicit, stating "The Chair... shall convene and preside over meetings of the Working Group, determine its agenda, direct work..." (Executive Order 13445: Strengthening Adult Education). Additionally, when actors are granted the power to establish groups or subcommittees, that is coded as agenda setting 
power because it provides actors the discretion to determine what issues are important enough to warrant an independent group.

\section{Coding Decisions for Authority}

1. Statutory Grant: Although all executive orders carry the full weight of the law (Cooper 2014), executive orders deriving their authority from statutory grants are viewed as more legitimate by both Congress and the courts (Howell 2003). When agencies are directed to act, having those required actions tied to a statute signals to executive agents there is backing from multiple branches of government and policy preferences are more closely aligned. This reduces doubts agencies face when multiple principals signal conflicting policy goals (Calvert, McCubbins \& Weingast 1989). Each executive order includes a vesting clause which states the authority the president is grounding the executive order in. The president can cite constitutional or commander in chief as a grant (Warber 2006), but when the president cites a specific statute in the vesting clause it is coded as an increase of authority.

2. Delegation: The president regularly uses executive orders to formally delegate responsibilities to actors. These delegations occur when the president explicitly identifies an actor and assigns them the authority to carry out a presidential function Congress bestowed upon the president in a statute. Delegations are coded as an increase in authority because it vests all the powers of the president in that actor, allowing them to pursue policy as if they were the president. The language used to code the delegation of authority is clear, it will state an actor and tie a statute to that actor's action.

3. Statutory Definition: Statutory definitions provide actors less discretion but more authority. The language used is clear, term $\mathrm{X}$ means $\mathrm{Y}$ as defined by statute $\mathrm{Z}$. There is less room for an 
agency to interpret the definition because its meaning is congressionally mandated and is applicable beyond the executive order it is used in. Because it has wider application, a common understanding will develop that aligns with congressional intent. While there is limited discretion, it does provide actors increased authority because there is consensus between the executive and legislative branch to align actions with that definition.

4. Procedures: When the president wants agencies and actors to carry out specific functions, procedures are included in an executive order. Procedures, such as those articulated by President W. Bush in Executive Order 13295: Revised List of Quarantine Communicable Diseases, limit the amount of discretion because they clearly articulate the rules agencies will be bound to during implementation to ensure specific goals of the president are accomplished. Here President Bush clearly identified Cholera, Diphtheria, infection Tuberculosis, Plague, Smallpox, Yellow Fever, and Viral Hemorrhagic Fevers as diseases requiring quarantine. Order with clearly articulate procedures provide increased authority because they clearly state specific outcomes the president wants achieved. Coding procedures is the most difficult category because the language can be similar to language articulating substantive goals. The difference comes in the level of specificity. As desired outcomes become more explicit, those goals become procedures.

5. Negative Powers: At times the president wants to ensure his order is fulfilled so specific negative, or enforcement, powers are granted to agencies. This grant of negative power allows agents to control or alter the behavior of actors with the threat or exercise of authority delegated from the president. Negative power comes in two forms. First, explicit language granting enforcement or sanction power is given to an agent, providing agencies with a "stick" 
to enforce compliance. President Clinton delegated this power to the Director of the Information Security Oversight Office, allowing him to take "corrective steps" for violations of the executive order (Executive Order 12958: Classified National Security Information). Second, language allowing agents to reject requests or applications is coded as constraint. It provides agents the authority to enforce the policy goals of the president by ensuring only those requests aligning with the president's goals are accepted.

6. Reporting - General: While reporting might seem like a constraint on actors, it is coded as an increase of authority because the reporting requirement ensures the actions, ideas, and opinions of actors are formally recognized. When undertaking actions to implement an executive order, either through information gathering or actions, a reporting requirement gives additional legitimacy to agency action. The language used will require either reporting or advising to an actor or actors that is not the president. For instance, President Reagan required the Secretary of the Interior to report to Congress on economic development plans for Micronesia and the Marshall Islands in Executive Order 12569: Compact of Free Association with the Republic of the Marshall Islands, the Federal States of Micronesia, and the Republic of Palau. Presidential reporting is treated separately.

7. Reporting - Presidential: The requirement to advise, assist, and/or make recommendations to the president increases agency authority because it provides them a direct line of communication to the president. It is assumed actors are more likely to comply if they know they have the ear of the president. Even if this involves cooperation with multiple agencies or organizations, the ability to influence a recommendation to the president is better than not being involved in the process. Language in executive orders used to code presidential advising 
calls for presidential advising or reporting directly. A special task force created by President Obama was required to provide a report to the president and several other actors concerning interrogation techniques in Executive Order 13491: Ensuring Lawful Interrogations.

8. Non-Federal Actors: We can no longer assume the sole target of an executive order is the federal bureaucracy and a measure must be included to capture the relationship non-federal actors have with executive orders (Warber 2014). When an executive order requires the staffing of non-federal actors, it is viewed as an increase of authority. The inclusion of non-

federal actors is most commonly associated with the creation of a policy or coordination group and the president will explicitly identify the groups to be included—state governments, local governments, Native American tribes, non-governmental agencies, academics etc... The inclusion of non-federal actors is viewed as an increase of authority because of the output it creates. When agencies pursue policies or make recommendations, they do so through the lens for their agency. Including multiple actors and views produces policies that might not align with any one agency's preferred policy. Multiple actors can create a coalition and develop policies to influence the final outcome (Sabatier \& Jenkins-Smith 1999). A final policy that includes the views of a wider range of actors is seen as more legitimate because there is a greater level of consensus.

\section{Coding Decisions for Amendments and Revocations}

1. Amendments and Revocations: Of the 3,199 executive orders coded for this project, 876 $(27.38 \%)$ were executive orders with the sole function of amending or revoking previous executive orders. These orders are dropped from the analysis, leaving 2,323 executive orders. There are multiple reasons to exclude these orders from the analysis. Amendment orders rarely give enough content to adequately analyze. In many cases the amendment orders do routine 
things like extend the date of a group's termination, add a member to group, or change a designee. Rarely do amendments change the substantive impact of the original executive order. Revocation orders also provide limited information, simply stating a previous order is revoked. Revocation orders do affect the substantive impact of the original order because it nullifies it. However, the purpose of this project is to determine how presidents use executive orders to interact with the bureaucracy and direct policy. This occurs when the original executive order is issued and policy has already been affected by the time the revocation occurs. An alternative option to excluding amendments and revocations would be to examine the original executive order and code the amendment or revocation based on the content of the original order. There are two major challenges with this method. First, some amendment and revocation orders are used for bulk amendments or revocations that cover multiple executive orders that might be coded differently. Second, some amendments and revocations target executive orders that are prior to this study's 1953 start date and go back to the founding where data is limited.

\section{Conclusion}

The bureaucratic control framework developed here provides a unique lens to examine executive orders through. They are not a single tool with a single function. Each order has a mixture of components that can be generalized when examining their content through this framework. Chapter 3: Types of Executive Orders and Trends Over Time provides a more in depth analysis of data to accomplish two things. First, the types of executive orders are deconstructed to examine the individual components likely to show up in each type of executive order. This will provide a better understanding on what constitutes each type of order. Second, the chapter will analyze the trends occurring across time to examine the evolution of executive 
orders. With a better understanding of executive order use, Chapter 4: Revisiting Strategic Executive Order Use, applies previous theories of executive order use in an attempt unify a divergent field. 
Chapter 3

Understanding Executive Orders: Types, Time, and Trends 
The previous chapter sketched a method to examine presidential executive orders. This new framework argues this single presidential tool has multiple purposes when viewed through the lens of bureaucratic controls focusing grants of discretion and authority. There is wide consensus that the president uses this tool to accomplish routine tasks (Mayer 2001; Howell 2003; Warber 2006), however, the president can also command specific bureaucratic action using coercive orders; guide bureaucratic agents and allow them to act with catalytic orders; or take advantage of the knowledge and expertise in the bureaucracy with hortatory orders. The theoretical framework for approaching the examination of executive orders is an important contribution to our understanding but the previous chapter also provided a practical approach, establishing the criteria necessary to systematically code executive orders in this sample.

This chapter applies the coding scheme articulated in the previous chapter to the 2,323 executive order from 1953 through $2012 .{ }^{3}$ This chapter proceeds in two main parts. First, the individual components are analyzed to better understand the application of coding criteria and gain leverage on the different elements in each type of executive order. Next, the types of executive orders are analyzed to identify trends using key variables consistent in presidential studies.

\section{Types of Executive Orders}

Most studies argue executive orders are used for multiple purposes but little research investigates how they are used. Coding executive orders through the framework developed in the previous chapter provides initial outcomes that advance the current understanding of executive order use. Table 3.1 presents the types of executive orders issued by the president. Importantly, this framework identifies greater variation in the types of executive orders than previous

\footnotetext{
${ }^{3}$ The full sample consists of 3,199 executive orders but executive orders with the main purpose of amending or revoking previous orders are excluded from the analysis. This consists of 876 executive orders.
} 
investigations measure. Most executive orders are used to accomplish routine matters. Routine executive orders account for $29.32 \%$ of the sample suggesting the executive order is still an important tool presidents use to ensure the regular operation of government. This leaves over two-thirds of orders unaccounted for.

Table 3.1: Executive Orders by Type, 1953-2012

\begin{tabular}{c|c|c} 
& $\begin{array}{c}\text { Discretion } \\
\text { Low (0-2) }\end{array}$ & $\begin{array}{c}\text { Discretion } \\
\text { High (3+) }\end{array}$ \\
\hline Authority & Routine & Hortatory \\
Low (0-2) & $29.32 \%$ & $21.48 \%$ \\
\hline Authority & Coercive & Catalytic \\
High (3+) & $22.73 \%$ & $26.47 \%$
\end{tabular}

Coercive orders most closely align with general conceptions and definitions of executive orders. They are direct commands from the president requiring specific action and providing bureaucratic agents the necessary authority to carry out that directive. However, this category accounts for only $22.73 \%$. Less than a quarter of executive orders are explicit commands to the bureaucracy. Instead, presidents are more likely to issue a catalytic order. In $26.47 \%$ of executive orders presidents shifted the policy process to bureaucratic agents, granting them the discretion to define policy and the authority to implement it. Finally, $21.48 \%$ of executive orders are hortatory. As discussed in the previous chapter, these orders are commonly used to establish a commission to gather information the president can use to inform policy. The information gathering function accounted for in hortatory order provides new insights into the purpose of executive order use. They are not only a tool to command and direct bureaucratic action, they can be used to collect information, inform the president, and take advantage of the expertise 
found in the executive branch. The levels of variation found here provides an important advance to the current understanding of executive orders. It shows executive orders have more nuances than previous research suggests, allowing the president to accomplish policy goals using different methods. While there is variation among orders, there is also variation within orders.

\section{Discretion}

Response rates to the questions developed in the previous chapter are reviewed in Table 3.2. Questions measuring discretion and authority are listed separately and are reviewed separately. The most common discretionary grant occurs when the president explicitly states agents need to implement the order. This occurs in $69.78 \%$ of the executive orders found in the sample. The high percentage of affirmative responses aligns with the types of orders being issued. Routine, coercive, and catalytic, accounting for $78.52 \%$ of executive orders, are the most likely to contain an implementation directive with hortatory orders limiting implementation.

The articulation of substantive goals and the ability for agents to control information receive the second highest levels of responses with $46.84 \%$ and $47.87 \%$, respectively. These responses also align with the types of executive orders issued. Both hortatory and catalytic orders, which account for $47.95 \%$ of all orders issued, are most likely to include substantive goals and allow agents to control information. The construction of these two types of orders in the previous chapter suggests these two elements should be present. Catalytic orders are issued to focus attention to a specific issue area and allow agents to carry out the order. Similarly, hortatory orders focus attention but call for information gathering instead of implementation. In both cases, the president needs to rely on the expertise of the bureaucracy and cannot provide 
Table 3.2: Affirmative Responses to Executive Orders, 1953-2012

\section{Questions of Discretion}

1. Does the executive order create a committee/task force/board with a policy focus?

2. Does the executive order create a committee/task force/board with a coordination focus?

3. Does the executive order contain substantive goals?

Number of Executive

Orders with an Affirmative

Response

Percentage of Executive

Orders with Affirmative

Response

638

379

$16.32 \%$

1088

$46.84 \%$

444

$19.11 \%$

4. Does the executive order contain a new definition not grounded in statute?

5. Does the executive order allow agencies to control information?

6. Does the executive order grant implementation power?

1112

$47.87 \%$

1621

$69.78 \%$

$17.56 \%$

7. Does the executive order grant rule-making power?

8. Does the executive order grant agenda setting

$5.51 \%$ power?

Questions of Authority

1. Does the president cite a specific statute in the vesting clause?

2. Does the executive order delegate statutory authority to an agent?

3. Does the executive order contain a definition grounded in statute?

4. Does the executive order articulate specific procedures to be followed?

5. Does the executive order grant agents negative powers?

6. Does the executive order include a general reporting and/or advising requirement?

7. Does the executive order include presidential reporting and/or advising requirement?

8. Does the executive order require the staffing of nonfederal actors?
Number of Executive

Orders with an Affirmative

Response

1751

786

291

1513

445

554

693

240
Percentage of Executive

Orders with Affirmative Response

$75.38 \%$

$33.84 \%$

$12.53 \%$

$65.13 \%$

$19.16 \%$

$23.85 \%$

$29.83 \%$

$10.3 \%$ 
specific goals. Broad, general objectives are used and agents are given the power to collect and control information to best interpret and meet the president's goals.

The remaining questions granting discretion fall below $20 \%$. In $19.11 \%$ of cases the president creates a new definition. The ability to engage in rule making is articulated in $17.56 \%$ of cases. The next two questions focus on the creation of a group. While coordination groups and policy groups receive $16.32 \%$ and $15.84 \%$, respectively, group creation accounts for $32.16 \%$ of cases. Within executive orders, the president can create different types of groups to accomplish different tasks. Throughout the coding process, efforts were made to make these groups mutually exclusive. Less than $1 \%$ of executive orders create both a coordination and policy group (see Table 3.3).

Finally, executive orders rarely grant agenda setting power. In only $5.51 \%$ of the cases does the president explicitly allow agents to set their own agenda. Agents inherently receive some agenda setting power through many of the discretionary grants they receive, however the explicit grant of agenda setting power provides and additional layer of discretion absent in most orders.

Table 3.3: Executive Orders Creating Groups, 1953-2012

\begin{tabular}{lcc}
\hline & No Coordination Group Created & Coordination Group Created \\
\hline No Policy Group Created & 1599 & 356 \\
& $(68.83 \%)$ & $(15.33 \%)$ \\
& & \\
Policy Group Created & 345 & 23 \\
& $(14.85 \%)$ & $(.99 \%)$ \\
\hline
\end{tabular}




\begin{abstract}
Authority
The provision of a vesting clause under grants of authority is the question that most commonly receives an affirmative response. In $75.38 \%$ of cases the president cites a specific statute as an executive order's legal foundation, providing it additional legitimacy. Attacks on the abuse of executive power are not limited to recent administrations. Presidents always contend with critics and grounding the exercise of executive power in a Congressional statue legitimizes the use of presidential power and grants executive agents additional authority to act. The next most common grant of authority is the articulation of specific procedures. At $65.13 \%$, procedures give agents the authority to act because they can point to specific text in an executive order to justify their actions, reducing slippage during interpretation.
\end{abstract}

The delegation of presidential authority to specific bureaucratic agents provides significant authority to act. In $33.84 \%$ of orders the president explicitly grants agents the ability to act with the full power of the president to implement an order. Two types of reporting requirements were coded, those that require reporting directly to the president and those that have a general reporting requirement but do not specifically mention the president. These reporting requirements are found in $29.83 \%$ and $23.85 \%$ of orders, respectively. Similar to group creation discussed under the section on discretion, efforts were taken to separate these two types of reporting requirements. The instance of orders including both reporting requirements is 12.10\%, (see Table 3.4). The number of orders containing at least one type of reporting requirement is $29.83 \%$, suggesting the importance of oversight on bureaucratic action.

Oversight is especially important when the president grants negative powers to bureaucratic agents. In $19.16 \%$ of orders the president provides agents with some "stick," or coercive authority, to ensure compliance with the order. The reporting and oversight function are 
Table 3.4: Executive Orders Requiring Advising or Reporting, 1953-2012

\begin{tabular}{lcc}
\hline & $\begin{array}{c}\text { No Presidential Advising } \\
\text { Requirement }\end{array}$ & $\begin{array}{c}\text { Presidential Advising } \\
\text { Requirement }\end{array}$ \\
\hline No Advising Requirement & 1357 & 412 \\
& $(58.42 \%)$ & $(17.74 \%)$ \\
Advising Requirement & & \\
& 273 & 281 \\
& $(11.75 \%)$ & $(12.10 \%)$ \\
\hline
\end{tabular}

discussed in further detail below. Definitions grounded in a specific statue are present in $12.53 \%$ of orders, 6.5 percentage points lower than discretionary definitions created by the president. Finally, $10.3 \%$ of orders require the staffing of non-federal actors. Responses to individual answers only provide an overview of the content of executive orders. Two aspects that require greater attention - group creation and reporting and advising requirements.

\section{Group Creation}

As Table 3.3 shows, $30.18 \%$ of orders create some type of group with just under 1\% of orders creating both types of groups. Table 3.5 reviews the affirmative responses for policy and coordination groups. Policy and coordination groups share some similarities but also have dramatic differences. In both cases, the president is likely to articulate substantive goals to direct the groups. Orders creating coordination groups contain slightly more incidences of substantive goals than policy groups with $94.99 \%$ compared to $92.12 \%$, respectively. Both receive a high likelihood of containing substantive goals suggesting the president does not create groups without providing a purpose.

Similarly, both groups are granted the discretion to control information in a high incidence of orders. Coordination groups receive this grant in $98.15 \%$ of cases and policy groups 
Table 3.5: Affirmative Responses to Executive Orders Creating Groups, 1953-2012

Questions of Discretion $\quad$ Policy Group Coordination Group

Does the executive order contain substantive goals?

339

$92.12 \%$

347

$94.29 \%$

114

$30.98 \%$

41

$11.14 \%$

79

$21.47 \%$
360

$94.99 \%$

372

$98.15 \%$

99

$25.12 \%$

20

$5.43 \%$

43

$11.68 \%$ setting power?

Questions of Authority general reporting and/or advising requirement?

Does the executive order include presidential reporting and/or advising requirement?

Does the executive order require the staffing of non-federal actors?
186

$50.54 \%$

151

$41.03 \%$

115

$31.25 \%$

31

$8.42 \%$

190

$51.63 \%$

253

$66.75 \%$

56

$14.78 \%$

65

$17.15 \%$

29

$7.65 \%$

$33.15 \%$

274

291

$74.46 \%$

$79.08 \%$

163

$44.29 \%$
73

$19.84 \%$ 
receive it $94.29 \%$ of the time. The high incidence of both conforms with expectations because coordination groups are created to manage information and policy groups need to collect information to make good policy.

Beyond substantive goals and the control of information, affirmative responses to discretionary questions drop for groups. Policy groups are more likely to receive implementation power at $30.98 \%$ compared to coordination groups at $25.12 \%$. Rule-making and agenda setting power provide the starkest contrast of discretionary grants. In each case, policy groups are almost twice as likely to receive these forms of discretion. Policy groups receive rule-making power $11.14 \%$ of the time and agenda setting power $21.47 \%$ of the time. Coordination groups receive these grants $5.43 \%$ of the time and $11.68 \%$ of the time, respectively.

Grants of authority are less balanced between policy and coordination groups with policy groups receiving more authority. In only two incidences do coordination groups have a higher incidence of affirmative responses to questions measuring authority. The first is the president's citation of a specific statute in the vesting clause. Orders creating a coordination group have a statutory vesting clause in $66.75 \%$ of cases, 16 percentage points higher than the policy groups' $50.54 \%$. There is a less dramatic difference in presidential reporting with coordination groups containing this requirement in $79.08 \%$ of cases and policy groups having it in $74.46 \%$ of cases. This provides important insights because in approximately $75 \%$ of orders where a group is created, presidential oversight is present.

The remaining questions measuring authority lean toward policy groups. Policy groups are more likely to have a general reporting requirement at $51.63 \%$ compared to $33.15 \%$ of coordination groups. The delegation of statutory authority is much stronger in policy groups with $41.03 \%$ receiving this grant compared to $14.78 \%$. There is also a greater likelihood the president 
articulates specific procedures for policy groups to follow. It makes sense that $31.25 \%$ of policy groups would have specific procedures because it is a way for the president to ensure implementation aligns with presidential policy goals. Executive orders creating coordination groups contain procedures in $17.15 \%$ of cases, suggesting they have more discretion to collect and manage information.

Both types of groups receive comparably low levels of coercive powers. Policy groups are slightly higher with $8.42 \%$ of cases granting such power with $7.65 \%$ of coordination groups receiving this grant. Finally, policy groups are more than twice as likely to require the inclusion of non-federal actors. In $44.29 \%$ of cases, policy groups are required to include non-federal actors compared to $19.84 \%$ of coordination groups. This speaks to the overall function of policy and coordination groups, suggesting policy groups are created to achieve results external to the bureaucracy and coordination groups are created to maintain cohesion within the bureaucracy and inform the president.

\section{Advising and Reporting}

Advising and reporting play an important role in executive order use. It allows the president or other actors to maintain accountability and stay informed about bureaucratic action. The reporting requirement becomes especially important when groups are created. However, groups are only created in approximately $30 \%$ of executive orders leaving significant room for bureaucratic action. Table 3.6 provides an overview of when bureaucratic agents are required to engage in reporting or advising when carrying out an executive order. Two general trends are apparent. First, it is more likely an executive order will include a presidential advising requirement over a general advising requirement. Second, when executive orders contain higher 
levels of discretion, they are more likely to have an advising requirement compared to executive orders containing higher levels of authority.

Table 3.6: Affirmative Responses to Executive Orders with Advising or Reporting Requirements, 1953-2012

\begin{tabular}{|c|c|c|}
\hline Questions of Discretion & $\begin{array}{c}\text { Advising } \\
\text { Requirement }\end{array}$ & $\begin{array}{l}\text { Presidential Advising } \\
\text { Requirement }\end{array}$ \\
\hline $\begin{array}{l}\text { Does the executive order contain } \\
\text { substantive goals? }\end{array}$ & $\begin{array}{c}422 \\
38.79 \%\end{array}$ & $\begin{array}{c}616 \\
56.62 \%\end{array}$ \\
\hline $\begin{array}{l}\text { Does the executive order allow agencies } \\
\text { to control information? }\end{array}$ & $\begin{array}{c}432 \\
38.85 \%\end{array}$ & $\begin{array}{c}647 \\
58.18 \%\end{array}$ \\
\hline $\begin{array}{l}\text { Does the executive order grant } \\
\text { implementation power? }\end{array}$ & $\begin{array}{c}335 \\
20.67 \%\end{array}$ & $\begin{array}{c}239 \\
14.74 \%\end{array}$ \\
\hline $\begin{array}{l}\text { Does the executive order grant rule- } \\
\text { making power? }\end{array}$ & $\begin{array}{c}124 \\
30.39 \%\end{array}$ & $\begin{array}{c}86 \\
21.08 \%\end{array}$ \\
\hline $\begin{array}{l}\text { Does the executive order grant agenda } \\
\text { setting power? }\end{array}$ & $\begin{array}{c}70 \\
54.69 \%\end{array}$ & $\begin{array}{c}94 \\
73.44 \%\end{array}$ \\
\hline Questions of Authority & $\begin{array}{c}\text { Advising } \\
\text { Requirement }\end{array}$ & $\begin{array}{c}\text { Presidential Advising } \\
\text { Requirement }\end{array}$ \\
\hline $\begin{array}{l}\text { Does the president cite a specific statute } \\
\text { in the vesting clause? }\end{array}$ & $\begin{array}{c}346 \\
19.76 \%\end{array}$ & $\begin{array}{c}455 \\
25.99 \%\end{array}$ \\
\hline $\begin{array}{l}\text { Does the executive order delegate } \\
\text { statutory authority to an agent? }\end{array}$ & $\begin{array}{c}206 \\
26.21 \%\end{array}$ & $\begin{array}{c}208 \\
26.46 \%\end{array}$ \\
\hline $\begin{array}{l}\text { Does the executive order articulate } \\
\text { specific procedures to be followed? }\end{array}$ & $\begin{array}{c}304 \\
20.09 \%\end{array}$ & $\begin{array}{c}222 \\
14.67 \%\end{array}$ \\
\hline $\begin{array}{l}\text { Does the executive order grant agents } \\
\text { negative powers? }\end{array}$ & $\begin{array}{c}148 \\
33.26 \%\end{array}$ & $\begin{array}{c}73 \\
16.40 \%\end{array}$ \\
\hline
\end{tabular}

Presidential advising and reporting is highest when discretion is granted to executive agents. Although the president does regularly grant executive agents the discretion to act, 
oversight still occurs. Presidents purposefully incorporate accountability checks to ensure executive orders are being implemented according to their preferences, most commonly when agents are given agenda setting power. While agents have the ability to determine their own work, presidents require direct feedback in $73.44 \%$ of cases and general feedback to other actors in $54.69 \%$ of cases. The high percentage of cases requiring reporting for agenda setting could be a product of the lower number of executive orders granting that discretionary power. Just 5.5\% of orders include this grant.

Rule-making accounts for a larger proportion of cases at $17.56 \%$, but receives lower levels of advising and reporting requirements. It is also one of the areas where there is a greater likelihood of general advising compared to presidential advising. In $30.39 \%$ of cases where rulemaking power is granted, there is a general advising requirement. This compares to $21.08 \%$ requiring presidential advising.

Implementation power also receives higher levels of general advising and reporting compared to presidential advising. When implementation power is granted, $20.67 \%$ of orders require general advising compared to $14.74 \%$ requiring presidential advising. Higher affirmative responses to reporting requirements accompanying rule-making and implementation is not surprising. Both involve processes that are more likely to engage with, and affect, actors outside the executive branch.

Other grants of discretion also require high levels of advising and reporting. The ability for executive agents to control information and the inclusion of substantive goals reach similar levels of advising and reporting. In 58.18\% of executive orders granting information control and $56.62 \%$ of orders providing substantive goals, agents are required to advise the president. The 
general reporting requirements are nearly 20 percentage points lower at $38.85 \%$ and $38.79 \%$, respectively.

When authority is granted to agents through an executive order, reporting requirements are still present but at lower levels compared to discretionary grants. Executive orders containing a statutory vesting clause receive low levels of advising and reporting requirements. Executive agents are required to advise the president in $25.99 \%$ of cases compared to $19.76 \%$ requiring a general advising requirement. The delegation of statutory authority to an agent commands nearly equal reporting requirements to both the president and other actors. Presidential advising is required $26.46 \%$ of the time and general reporting is required $26.21 \%$ of the time. The articulation of specific procedures receives even lower levels of advising requirements. Agents are required to advise the president in $14.67 \%$ of cases and advise other actors in $20.09 \%$ of cases. Lower levels of advising for grants of authority is not surprising. Authority grants are more specific, reducing the ability of agents to interpret the grant and drift from presidential preferences.

The only grant of authority receiving high levels of advising and reporting are grants of coercive powers. When agents have this power, they are required to advise the president $16.40 \%$ of the time and other actors $33.26 \%$ of the time. Negative power provides executive agents the greatest ability to affect other actors, because agents get coercive powers. Two points are important to make. First, coercive power is not frequently included, being granted in $19.16 \%$ of executive orders. Second, when it is granted, there are efforts to ensure oversight is occurring. Importantly, this oversight is almost twice as likely to occur by actors other than the president. This indicates the president's willingness to shift to the oversight function when granting bureaucratic agents a significant power. 
The advising and reporting requirement provide an important function to executive order use. It is a way for the president to ensure implementation aligns with presidential polices. This is a necessary oversight mechanism for presidents to ensure slippage does not occur and allows outside actors to monitor the exercise of presidential power.

Examining responses to individual questions provides general insight to the use of executive orders but does not provide insights to the composition of different types of executive orders. The next section analyzes the different types of executive orders.

\section{Routine - Hortatory - Coercive - Catalytic}

The types of executive orders issued are composed of different components and this section examines the composition of the different types of executive orders. Routine orders should have low levels of responses in both the discretion and authority categories. Hortatory orders should have a higher incidence of responses from the discretionary category and lower incidence of responses from the authority category. Coercive orders should receive high incidences of responses from the authority category and low incidences of responses from the discretion category. Finally, catalytic orders should receive high incidences of responses from both the discretion and authority categories. Table 3.7 provides an overview the affirmative responses to each question within each type of executive order.

Routine Executive Orders: Many routine orders have incidences of statutory grants and procedures; however, they can contain some level of discretion. The composition of affirmative responses for each type of executive order aligns with the exceptions of their purpose. Routine executive orders receive low levels of responses across most questions with three major exceptions. Routine orders have one high incidence of response under discretion and two high incidences of response under authority. In $83.70 \%$ of routine orders the president grants 
discretion though implementation power to agents. For instance, President Johnson issued Executive Order 11201: Inspection of Income, Excess-Profits, Estate, and Gift Tax Returns by Government Operations, House of Representatives on March 4, 1965. While this order was still comprised of a statutory grant and procedures, it also provided implementation power. Under the category of authority, $87.22 \%$ of routine orders contain specific procedures to be followed and $74.45 \%$ of orders cite a specific statute as the vesting clause. On May 18, 1959 President Eisenhower issued a common routine executive order prescribing the order of succession for Secretary of Defense. This order was grounded in a statutory grant and clearly delineated procedures to be followed in the event the Secretary of Defense dies or is unable to perform their duties. The high incidence of affirmative responses to these three questions are not surprising. Routine executive orders do not have a significant impact on policy but do require some discretion and authority for implementation.

Presidents provide this by including a grant of implementation power but are also likely to delineate specific procedures which must be followed. Routine orders are also likely to be grounded in a specific statutory grant, though at lower rates than coercive and catalytic orders. Statutory vesting clauses in routine orders do surpass hortatory orders by nearly 27 percentage points. Because routine orders do not influence policy as much as the other types of orders, the inclusion of a statutory vesting clause is likely to have less of an impact on the actual implementation of the executive order. 
Table 3.7: Affirmative Responses by Executive Order Type, 1953-2012

\begin{tabular}{|c|c|c|c|c|}
\hline Questions of Discretion & Routine & Hortatory & Coercive & Catalytic \\
\hline $\begin{array}{l}\text { 1. Does the executive order create a } \\
\text { committee/task force/board with a } \\
\text { policy focus? }\end{array}$ & $\begin{array}{c}7 \\
1.03 \%\end{array}$ & $\begin{array}{c}135 \\
27.05 \%\end{array}$ & $\begin{array}{c}9 \\
1.70 \%\end{array}$ & $\begin{array}{c}217 \\
35.28 \%\end{array}$ \\
\hline $\begin{array}{l}\text { 2. Does the executive order create a } \\
\text { committee/task force/board with a } \\
\text { coordination focus? }\end{array}$ & $\begin{array}{c}4 \\
0.59 \%\end{array}$ & $\begin{array}{c}250 \\
50.10 \%\end{array}$ & $\begin{array}{c}5 \\
0.95 \%\end{array}$ & $\begin{array}{c}120 \\
19.51 \%\end{array}$ \\
\hline $\begin{array}{l}\text { 3. Does the executive order contain } \\
\text { substantive goals? }\end{array}$ & $\begin{array}{c}64 \\
9.40 \%\end{array}$ & $\begin{array}{c}455 \\
91.18 \%\end{array}$ & $\begin{array}{c}84 \\
15.91 \%\end{array}$ & $\begin{array}{c}485 \\
78.86 \%\end{array}$ \\
\hline $\begin{array}{l}\text { 4. Does the executive order contain a } \\
\text { new definition not grounded in } \\
\text { statute? }\end{array}$ & $\begin{array}{c}77 \\
11.31 \%\end{array}$ & $\begin{array}{c}83 \\
16.63 \%\end{array}$ & $\begin{array}{c}44 \\
8.33 \%\end{array}$ & $\begin{array}{c}240 \\
39.02 \%\end{array}$ \\
\hline $\begin{array}{l}\text { 5. Does the executive order allow } \\
\text { agencies to control information? }\end{array}$ & $\begin{array}{c}114 \\
16.74 \%\end{array}$ & $\begin{array}{c}447 \\
89.58 \%\end{array}$ & $\begin{array}{c}79 \\
14.96 \%\end{array}$ & $\begin{array}{c}472 \\
76.75 \%\end{array}$ \\
\hline $\begin{array}{l}\text { 6. Does the executive order grant } \\
\text { implementation power? }\end{array}$ & $\begin{array}{c}570 \\
83.70 \%\end{array}$ & $\begin{array}{c}187 \\
37.47 \%\end{array}$ & $\begin{array}{c}458 \\
86.74 \%\end{array}$ & $\begin{array}{c}406 \\
66.02 \%\end{array}$ \\
\hline $\begin{array}{l}\text { 7. Does the executive order grant rule- } \\
\text { making power? }\end{array}$ & $\begin{array}{l}33 \\
4.85 \%\end{array}$ & $\begin{array}{c}82 \\
16.43 \%\end{array}$ & $\begin{array}{c}57 \\
10.80 \%\end{array}$ & $\begin{array}{c}236 \\
38.37 \%\end{array}$ \\
\hline $\begin{array}{l}\text { 8. Does the executive order grant } \\
\text { agenda setting power? }\end{array}$ & $\begin{array}{c}0 \\
0 \%\end{array}$ & $\begin{array}{c}56 \\
11.22 \%\end{array}$ & $\begin{array}{c}2 \\
0.38 \%\end{array}$ & $\begin{array}{c}70 \\
11.38 \%\end{array}$ \\
\hline Questions of Authority & Routine & Hortatory & Coercive & Catalytic \\
\hline $\begin{array}{l}\text { 1. Does the president cite a specific } \\
\text { statute in the vesting clause? }\end{array}$ & $\begin{array}{c}507 \\
74.45 \%\end{array}$ & $\begin{array}{c}237 \\
47.49 \%\end{array}$ & $\begin{array}{c}503 \\
95.27 \%\end{array}$ & $\begin{array}{c}504 \\
81.95 \%\end{array}$ \\
\hline $\begin{array}{l}\text { 2. Does the executive order delegate } \\
\text { statutory authority to an agent? }\end{array}$ & $\begin{array}{c}46 \\
6.75 \%\end{array}$ & $\begin{array}{c}24 \\
4.81 \%\end{array}$ & $\begin{array}{c}379 \\
71.78 \%\end{array}$ & $\begin{array}{c}337 \\
54.80 \%\end{array}$ \\
\hline $\begin{array}{l}\text { 3. Does the executive order contain a } \\
\text { definition grounded in statute? }\end{array}$ & $\begin{array}{c}8 \\
1.17 \%\end{array}$ & $\begin{array}{l}15 \\
3.01 \%\end{array}$ & $\begin{array}{c}127 \\
24.05 \%\end{array}$ & $\begin{array}{c}141 \\
22.93 \%\end{array}$ \\
\hline $\begin{array}{l}\text { 4. Does the executive order articulate } \\
\text { specific procedures to be followed? }\end{array}$ & $\begin{array}{c}594 \\
87.22 \%\end{array}$ & $\begin{array}{c}97 \\
19.44 \%\end{array}$ & $\begin{array}{c}427 \\
80.87 \%\end{array}$ & $\begin{array}{c}395 \\
64.23 \%\end{array}$ \\
\hline $\begin{array}{l}\text { 5. Does the executive order grant } \\
\text { agents negative powers? }\end{array}$ & $\begin{array}{c}16 \\
2.35 \%\end{array}$ & $\begin{array}{c}17 \\
3.41 \%\end{array}$ & $\begin{array}{c}188 \\
35.61 \%\end{array}$ & $\begin{array}{c}224 \\
36.42 \%\end{array}$ \\
\hline $\begin{array}{l}\text { 6. Does the executive order include a } \\
\text { general reporting and/or advising } \\
\text { requirement? }\end{array}$ & $\begin{array}{c}12 \\
1.76 \%\end{array}$ & $\begin{array}{c}102 \\
20.44 \%\end{array}$ & $\begin{array}{c}102 \\
19.32 \%\end{array}$ & $\begin{array}{c}277 \\
45.04 \%\end{array}$ \\
\hline $\begin{array}{l}\text { 7. Does the executive order include } \\
\text { presidential reporting and/or } \\
\text { advising requirement? }\end{array}$ & $\begin{array}{c}9 \\
1.32 \%\end{array}$ & $\begin{array}{c}290 \\
58.12 \%\end{array}$ & $\begin{array}{c}54 \\
10.23 \%\end{array}$ & $\begin{array}{c}340 \\
55.28 \%\end{array}$ \\
\hline $\begin{array}{l}\text { 8. Does the executive order require the } \\
\text { staffing of non-federal actors? }\end{array}$ & $\begin{array}{c}0 \\
0 \%\end{array}$ & $\begin{array}{l}45 \\
9.02 \%\end{array}$ & $\begin{array}{c}13 \\
2.46 \%\end{array}$ & $\begin{array}{c}182 \\
29.59 \%\end{array}$ \\
\hline
\end{tabular}


Other questions receive even lower levels of response rates with only two peaking above $10 \%$. In $16.74 \%$ of cases the president grants agents the discretion to control information and in $11.31 \%$ of cases the president includes a new definition not grounded in a statute. However, these are relatively low levels of affirmative responses and most questions in routine orders fall below $5 \%$.

Hortatory Executive Orders: Presidents regularly contend with issues they do not have full information about but require informed decision-making. Hortatory groups are commonly used gather and provide expert information to the president. When President Carter was formulating foreign policy with Liberia, he issued Executive Order 12195: President's Commission on United States-Liberian Relations. This order established a coordination group, provided substantive goals, and allowed that group to coordinate and gather information to present to the president. Hortatory orders receive more affirmative responses under the discretion category. This is where the highest proportion of groups are created with $27.05 \%$ being policy groups and $50.10 \%$ being coordination groups. These orders also contain substantive goals and grant agents the ability to control information in most cases, $91.18 \%$ and $89.58 \%$ respectively. Affirmative responses to these questions align with the idea that they are used to take advantage of the expertise found in the executive branch without providing agents the authority to implement policy. Responses under the authority category are generally low with reporting requirements and the citation of a specific statute in the vesting clause being the exceptions.

The inclusion of reporting requirements is not surprising for hortatory orders. Hortatory orders are used to collect information and provide it to actors so they can make informed policy decisions with consistent information. Once information is collected, explicit reporting requirements are included to ensure that information is disseminated. While these are the most 
common responses found under hortatory orders, $37.47 \%$ of hortatory orders have implementation power, approximately $16 \%$ include a presidential definition and rule-making power, and $11.22 \%$ include agenda setting power. Under the authority category, the only other question that rises above 5\% is the inclusion of non-federal actors. While their inclusion is not high, accounting for $9.02 \%$ of all hortatory orders, outside actors can provide additional information to provide a more complete picture of the issue articulated in the executive order.

Coercive Executive Orders: Coercive orders receive the most affirmative responses in the category of authority. These orders are a way for the president to reach into the bureaucracy and direct specific action. President W. Bush used several elements of authority this when he issued Executive Order 13460: Blocking Property of Additional Persons in Connection with the National Emergency with Respect to Syria. This order was issued to help mitigate Syria's role in destabilizing Iraq in 2008. The vesting clause contains several statutory grants and includes clear procedures to follow when blocking transactions between American citizens and officials of the Syrian government.

President Bush's order contains the most common component of coercive orders, the citation of a specific statute in the vesting clause. As a proportion of responses within a type of executive order, the inclusion of the statute is the most frequent affirmative answer in coercive orders at $95.27 \%$. When presidents use this tool as a coercive measure, they understand specificity is required which is why $80.87 \%$ also include detailed procedures to be followed. The combination of these two elements allow the president to accomplish specific tasks but insulates the president from some scrutiny by vesting the order in a congressional statute.

One of the most common uses of coercive orders is to delegate statutory authority to an executive agent, allowing the agent to act with the powers of the president in an exclusive policy 
area. President Nixon delegated his authority under the Fisherman's Protective Act of 1967 to the Secretary of State in Executive Order 11772. It empowered the Secretary of State to act as a surrogate for the president, vesting all power and authority of the president in the secretary. Delegation occurs in $71.78 \%$ of cases, showing how useful of a tool this is to the president. The remaining responses under authority drop below fifty percent. The grant of negative powers to executive agents occurs in $35.61 \%$ of coercive orders, highlighting the command present in this type of executive order.

Vesting the entire coercive order in a specific statute is common, but including a statutory definition within the body of the executive order is less common at $24.05 \%$. Reporting requirements are included in approximately $30 \%$ of coercive orders with general reporting occurring in $19.32 \%$ of cases and presidential reporting occurring in $10.23 \%$. Finally, only $2.46 \%$ of coercive orders include non-federal actors. While the absence of non-federal actors reduces the amount of authority granted to executive agents because there are no external agents to legitimize actions, it allows agents to implement the order more quickly and efficiently.

Most affirmative responses for coercive orders under the discretion category fall below fifteen percent. The one exception is the grant of implementation power, found in $86.74 \%$ of coercive orders. As discussed in the previous chapter, the implementation power does provide some authority but is coded as discretion because, unlike specific procedures, it is general and allows agents to determine how they will implement the order. However, it still provides agents the ability to carry out the coercive order. This compares to only $14.96 \%$ or orders granting agents control over information. The high response rate of implementation and low level of information control, coupled with high levels of procedural requirements, shows coercive orders 
are used to accomplish specific goals. Agents are most likely carrying out specific commands from the president which is why only $15.95 \%$ of coercive orders contain substantive goals.

Rule-making power, agenda setting power, and new presidential definitions are relatively low at $10.80 \%, 0.38 \%$, and $8.33 \%$, respectively. This speaks to the president's desire to limit agents' ability to develop rules beyond the scope of the executive order. Groups are rarely created for coercive orders with policy group creation occurring in $1.70 \%$ of orders and coordination group creation occurring in $0.95 \%$. The low level of group creation is because coercive orders are tools for targeted use. There is little need to create a policy group because presidents are issuing coercive orders to achieve specific goals.

Catalytic Executive Orders: The final type of executive orders issued are catalytic orders. While these orders receive balanced response rates in the categories of discretion and authority, they are some of the most significant executive orders. They provide agencies the ability to interpret an order and the authority necessary to implement it. For instance, President Clinton issued Executive Order 13160 in an attempt to reduce discrimination in federally conducted education and training programs. It sets a broad substantive goal that no individual shall be discriminated against based on race, sex, color, national origin, disability, religion, age, sexual orientation, or status as a parent but then leaves it to the Attorney General to determine when this type of discrimination has occurred. When it is determined that discrimination has occurred, the Attorney General has the power to enforce the order by issuing corrective measures. The procedures that are included focus on entities like the military which are explicitly exempt from this executive order. This order, and catalytic orders similar to it, gives agencies significant discretion to interpret what discrimination looks like and provides the authority to take corrective steps. 
There is a high proportion of catalytic orders containing substantive goals similar to Clinton's, $78.86 \%$. They also commonly contain the ability to control information, $76.75 \%$. While high, these numbers are still lower than those found in hortatory orders. Catalytic orders differ because they receive greater grants of implementation power. Catalytic orders receive implementation grants in $66.02 \%$ of orders compared to $37.47 \%$ of hortatory orders. While group creation is lower than the $77.15 \%$ created in hortatory orders, there is a higher incidence of policy groups created. Groups are created $54.79 \%$ of catalytic orders, with $35.28 \%$ having a policy focus and $19.51 \%$ having a coordination focus. Catalytic orders also contain a higher proportion of rule-making and agenda setting power at $38.37 \%$ and $11.38 \%$, respectively. The last question in the discretion category is the inclusion of a new definition not grounded in a statute. This question also has more affirmative responses in catalytic orders at 39.02\%.

Looking at just questions of discretion suggests catalytic orders are similar to hortatory ones. In most cases, they receive affirmative responses at about the same rate. However, catalytic orders have a higher proportion of responses that favor issues of policy. This is most notable in the higher rate of policy groups, the type of implementation power granted, and greater control over the agenda and rule-making. However, the biggest difference is apparent when examining questions of authority. As noted during the discussion of hortatory orders, response rates for hortatory orders are relatively low with a few exceptions. Catalytic orders receive high rates of affirmative responses because presidents use them as a tool to guide bureaucratic action and provide the authority to implement policy.

Similar to other types of executive orders, the highest response rate is the inclusion of a specific statute in the vesting clause at $81.95 \%$. Catalytic orders have the greatest potential impact on policy because it provides executive agents both discretion and authority in a specific 
policy area. Because of this, presidents include statutes in the vesting clause to mitigate criticisms. The remaining responses, while high, are not overwhelmingly so. Specific procedures are articulated in $64.23 \%$ of orders, the second highest response rate for catalytic orders under the category of authority. Just over half of catalytic orders, $54.80 \%$, delegate statutory authority to an executive agent and less than one quarter, $22.93 \%$, include a statutory definition in the body of the executive order. Proportions for each of these response rates are lower than coercive orders with the most pronounced differences occurring in the delegation of authority, which is approximately 17 percentage points lower in catalytic orders, and specific procedures, which is approximately 16.5 percentage points lower. The lower rates in catalytic orders conform to their use. There is less of a need to delegate specific authority because agents are receiving higher rates of discretion.

Catalytic orders have higher response rates in the remaining categories, compared to coercive orders. In only a slightly higher proportion of responses do catalytic orders include negative powers, $36.42 \%$ compared to $35.61 \%$. However, catalytic orders have more of these grants in raw numbers, 224 compared to 188 . The negative power along with high amounts of discretion requires a high level of oversight, making advising, reporting, and the inclusion of non-federal actors the highest across order types. The one exception lies in hortatory orders where $58.12 \%$ require presidential advising compared to $55.28 \%$ of catalytic orders. Catalytic orders also require general advising and reporting in $45.04 \%$ of cases which is more than double any of the other types of executive orders. Finally, there is a much higher inclusion of nonfederal actors at $29.59 \%$. When presidents issue these orders, they are broad and provide executive agents the ability to act. Like most other types of executive orders, presidents attempt to build in accountability checks when possible to mitigate charges of executive overreach. In 
catalytic orders, the most expansive type of order, presidents ground orders in statutes, have high levels of advising and reporting requirements, and allow non-federal actors to participate in the implementation process.

Questions to measure discretion and authority, along with cut points, were developed prior to their application to the sample. The analysis of affirmative responses and their presence within each type of executive order bolster the theoretical framework established in the previous chapter. The previous analysis shows executive order are used for different purposes and each type has unique characteristics that help the order accomplish different goals. With a complete understanding of the types of executive orders and their makeup, general trends can now be gleaned from the sample.

\section{Issuing Executive Orders}

The first noticeable trend is an important one, the composition of executive orders issued over time has changed. According to Mayer (2001), Howell (2003), and Warber (2006), executive orders follow a downward trend, with each president issuing fewer executive orders than their predecessor. However, each also argues the scope and importance of these orders are increasing, with presidents using executive orders to accomplish more significant policy goals (Warber 2006). If the theoretical framework developed here applies to these arguments, several trends should be apparent in the data. First, there should be a downward trend across most types of executive orders. Routine orders should have the greatest decrease as bureaucratic agencies assumed most routine tasks over time. Second, hortatory orders should have a slight decline but remain relatively constant over time because they are used to gather information, something all presidents need to make informed policy decisions. Third, coercive orders should show a downward trend, aligning with the general downward trend of executive order use. Finally, 
catalytic orders should be the only type of order showing an upward trend because they have the greatest policy focus and allow the president to get the most accomplished unilaterally. Catalytic executive orders should represent the upward trend in significant, policy related executive orders previous research finds.

Figure 3.1 provides four trend lines, one for each type of executive order. This figure confirms expectations: routine orders have the most dramatic trend with a slope of -0.262 . Hortatory orders have a slight downward trend but remain fairly constant with a slope of -0.060 . A similar downward trend is found in coercive orders with a slope of -0.152. Finally, catalytic orders do have a positive slope of 0.074 . The trend for catalytic orders is not as pronounced as the decrease apparent in routine orders, but the trend line is positive when the overall number of executive orders is decreasing.

Table 3.8 extends this analysis, examining how presidents from Eisenhower to Obama have used different types of executive orders across their administration. President Eisenhower issues the most routine orders in total and on average. During his eight years as president he issued 156 routine orders, amounting to 19.5 a year. Following Eisenhower, there is a drop from the Kennedy to Carter administrations. During these five administrations, presidents issued approximately 14.80 routine orders a year. A more significant drop occurs during the Reagan years and continues through Obama with president's issuing approximately 6.98 routine orders a 
Figure 3.1: Executive Order Types Across Time, 1953-2012
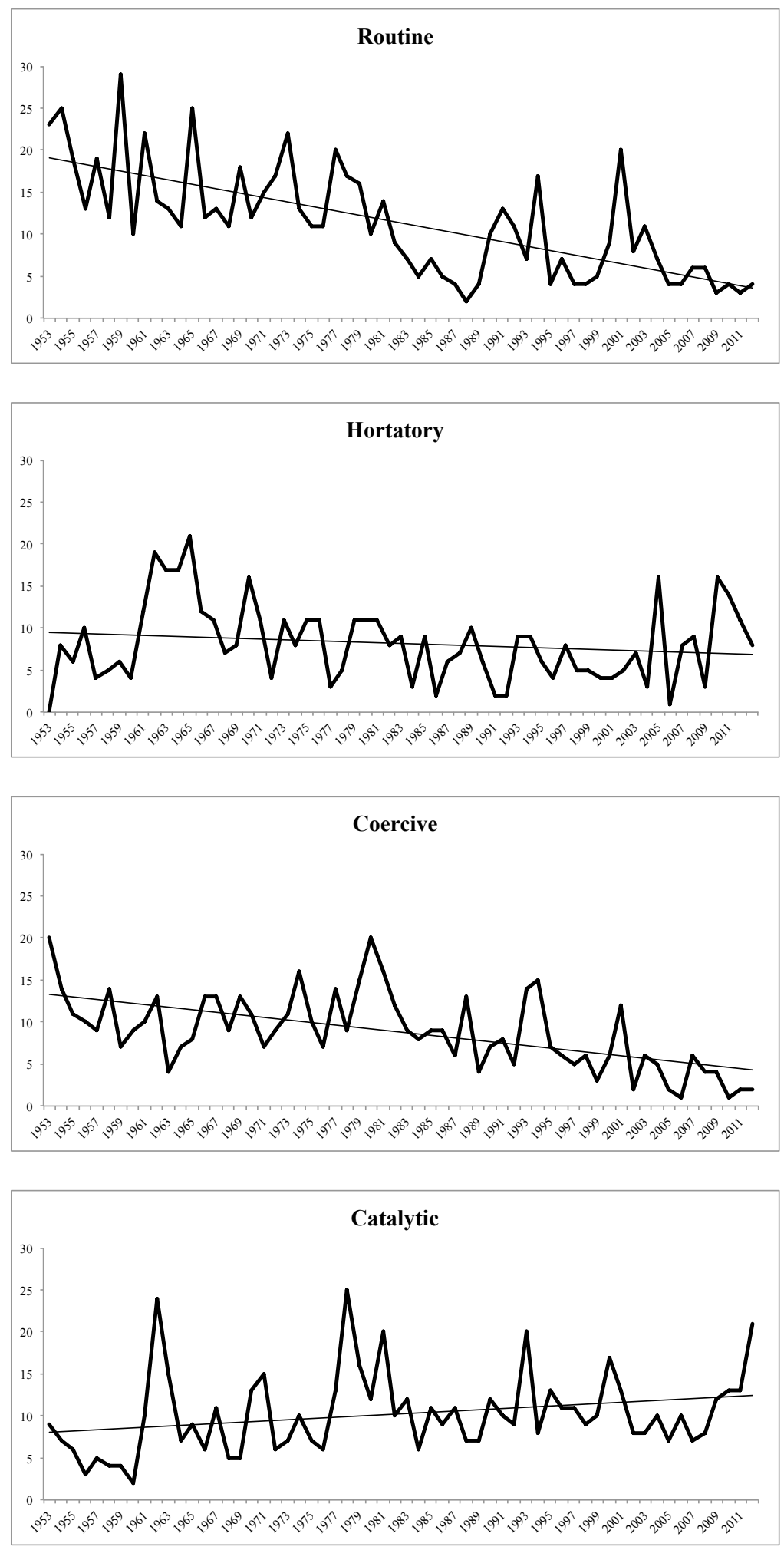

56 
year. Obama issued the fewest routine orders with only 3.5 a year. This represents the strong downward trend in routine orders as agencies grew larger and subsumed more routine functions of the executive branch.

Table 3.8: Executive Orders by President, 1953-2012

\begin{tabular}{|c|c|c|c|c|}
\hline President & Routine & Hortatory & Coercive & Catalytic \\
\hline Eisenhower & $\begin{array}{c}156 / 19.50 \\
(44.8 \%)\end{array}$ & $\begin{array}{c}56 / 7 \\
(16.1 \%)\end{array}$ & $\begin{array}{c}94 / 11.75 \\
(27.0 \%)\end{array}$ & $\begin{array}{l}42 / 5.25 \\
(12.1 \%)\end{array}$ \\
\hline Kennedy & $\begin{array}{c}40 / 14.12 \\
(34.5 \%)\end{array}$ & $\begin{array}{c}49 / 17.30 \\
(30.0 \%)\end{array}$ & $\begin{array}{c}27 / 9.53 \\
(16.6 \%)\end{array}$ & $\begin{array}{c}47 / 16.59 \\
(28.8 \%)\end{array}$ \\
\hline Johnson & $\begin{array}{c}77 / 14.91 \\
(32.9 \%)\end{array}$ & $\begin{array}{l}68 / 13.16 \\
(29.1 \%)\end{array}$ & $\begin{array}{l}51 / 9.87 \\
(21.8 \%)\end{array}$ & $\begin{array}{c}38 / 7.36 \\
(16.2 \%)\end{array}$ \\
\hline Nixon & $\begin{array}{c}88 / 15.76 \\
(35.1 \%)\end{array}$ & $\begin{array}{l}48 / 8.60 \\
(19.1 \%)\end{array}$ & $\begin{array}{c}62 / 11.11 \\
(24.7 \%)\end{array}$ & $\begin{array}{l}53 / 9.49 \\
(21.1 \%)\end{array}$ \\
\hline Ford & $\begin{array}{c}35 / 14.48 \\
(35.4 \%)\end{array}$ & $\begin{array}{l}21 / 8.69 \\
(21.2 \%)\end{array}$ & $\begin{array}{c}26 / 10.76 \\
(26.3 \%)\end{array}$ & $\begin{array}{c}17 / 7.03 \\
(17.2 \%)\end{array}$ \\
\hline Carter & $\begin{array}{c}59 / 14.75 \\
(25.2 \%)\end{array}$ & $\begin{array}{c}42 / 10.50 \\
(17.9 \%)\end{array}$ & $\begin{array}{c}60 / 15 \\
(25.6 \%)\end{array}$ & $\begin{array}{l}73 / 18.25 \\
(31.2 \%)\end{array}$ \\
\hline Reagan & $\begin{array}{l}51 / 6.38 \\
(19.8 \%)\end{array}$ & $\begin{array}{l}52 / 6.50 \\
(20.2 \%)\end{array}$ & $\begin{array}{l}75 / 9.38 \\
(29.2 \%)\end{array}$ & $\begin{array}{l}79 / 9.88 \\
(30.7 \%)\end{array}$ \\
\hline Bush I & $\begin{array}{l}39 / 9.75 \\
(32.5 \%)\end{array}$ & $\begin{array}{c}18 / 4.5 \\
(15.0 \%)\end{array}$ & $\begin{array}{c}25 / 6.25 \\
(20.8 \%)\end{array}$ & $\begin{array}{l}38 / 9.50 \\
(31.7 \%)\end{array}$ \\
\hline Clinton & $\begin{array}{c}58 / 7.25 \\
(21.7 \%)\end{array}$ & $\begin{array}{l}46 / 5.75 \\
(17.2 \%)\end{array}$ & $\begin{array}{l}62 / 7.75 \\
(23.2 \%)\end{array}$ & $\begin{array}{c}101 / 12.63 \\
(37.8 \%)\end{array}$ \\
\hline Bush II & $\begin{array}{c}64 / 8 \\
(10.7 \%)\end{array}$ & $\begin{array}{l}52 / 6.50 \\
(23.2 \%)\end{array}$ & $\begin{array}{c}39 / 4.88 \\
(17.4 \%)\end{array}$ & $\begin{array}{c}69 / 8.63 \\
(30.8 \%)\end{array}$ \\
\hline Obama & $\begin{array}{c}14 / 3.5 \\
(11.1 \%)\end{array}$ & $\begin{array}{l}47 / 11.75 \\
(37.3 \%)\end{array}$ & $\begin{array}{l}7 / 1.75 \\
(5.6 \%)\end{array}$ & $\begin{array}{c}58 / 14.50 \\
(46.0 \%)\end{array}$ \\
\hline
\end{tabular}

Total/Yearly Average (percentage by president)

As stated above, hortatory orders follow a similar downward trend, however, the trend differs from routine. Routine orders can be divided into three general time periods - 1953 to 1961 - 1961 to 1981 - 1981 to 2013 . Hortatory orders differ more by party than time. Republicans issue approximately 7 hortatory orders a year compared to approximately 11.5 a year for Democrats. Republicans also issue hortatory orders fairly consistently over time, whereas Democrats see a drop over time. Because Republicans issue hortatory orders more consistently, 
Democrats have the highest and lowest annual average with President Kennedy issuing 17.30 a year and President Clinton issuing 5.75 a year.

Coercive orders are the most stable across administrations with a slight drop occurring after the Reagan years. The range of coercive orders between Eisenhower and Reagan is 9.38 to 15 with an average of 11.06 annually. After Reagan, the annual average drops to 5.16 with President Obama issuing only 1.75 a year.

Catalytic orders are similar to hortatory and fluctuate based on party more than time. While the general trend of catalytic orders is upward, Democrats consistently use this tool more than Republicans. Democrats issue 13.87 catalytic orders a year compared to 8.30 annually from Republicans. Trends across time and trends across administrations tell a complementary story but the examination of executive order use by administration adds an additional layer. This analysis suggest Democrats and Republicans are using orders differently.

Table 3.9 suggests Democrats and Republicans use executive orders differently. The first observation is that Republicans issued more executive orders than Democrats in total. However, that is largely a product of White House control. Republicans held the White House for 36 years of the sample compared to the 24 years Democrats held it. Yearly averages are more telling of the difference between executive order use by Republicans and Democrats with Republicans issuing an average of 36.08 executive orders yearly compared 42.66 yearly by Democrats.

Table 3.9: Types of Executive Orders by Party, 1953-2012

\begin{tabular}{lcccc}
\hline & Routine & Hortatory & Coercive & Catalytic \\
\hline \multirow{2}{*}{ Republican } & 433 & 247 & 321 & 298 \\
& $(33.3 \%)$ & $(19.0 \%)$ & $(24.7 \%)$ & $(22.9 \%)$ \\
Democrat & 248 & 252 & 207 & 317 \\
& $(24.2 \%)$ & $(24.6 \%)$ & $(20.2 \%)$ & $(31.0 \%)$ \\
\hline
\end{tabular}


The totals are illustrative but the types of orders issued also matters. Republicans issue more routine orders, mostly because Eisenhower issued 156 routine orders, significantly more than any other president. Both parties have issued nearly the same number of hortatory orders but Democrats issue them more frequently. Coercive and catalytic orders produce the most interesting differences. Republicans are more likely to use executive orders as a coercive tool while Democrats are more likely to use orders as a catalytic tool. These patterns align with some general conceptions of Republicans and Democrats that suggests Republicans favor a centralized system of small government and Democrats favor a decentralized system with large government. Coercive orders, accounting for $24.71 \%$ of Republican orders, provide increased specificity over how and what agents will implement, providing the president increased control. Catalytic orders, accounting for $30.96 \%$ of Democratic orders, shift the development and implementation of policy into the hands of bureaucratic agents reducing control of the president.

Partisanship of the president clearly has an influence on the type of executive orders issued but the president does not operate in a political vacuum. The other branches of government, specifically Congress, influences the president's strategic calculations when deciding to issue an executive order (Howell 2003). The most commonly analyzed institutional relationship between the executive and legislative branch is determined if a single party holds the White House, Senate, and House. This institutional make up creates a system of unified government. Divided government occurs when the opposition party controls at least one of these institutions. Unified government occurs in 24 years of the sample and divided government occurs in 38 years of the sample. As many suggest, this relationship should affect the president's propensity to issue different types of executive orders (Mayer 2001; Howell 2003; Warber 2006). 
Table 3.10: Types of Executive Orders Under Unified and Divided Government, 1953-2012

\begin{tabular}{lcc}
\hline & Unified Government & Divided Government \\
Routine & 307 & 374 \\
& $(45.1 \%)$ & $(54.9 \%)$ \\
Hortatory & 253 & 246 \\
& $(50.7 \%)$ & $(49.3)$ \\
Coercive & 231 & 297 \\
& $(43.8 \%)$ & $(56.3 \%)$ \\
Catalytic & 278 & 337 \\
& $(45.2 \%)$ & $(54.8 \%)$ \\
& 1069 & 1254 \\
\hline
\end{tabular}

Table 3.10 shows the types of executive orders issued during unified and divided government. Hortatory orders are the only type that is balanced with $50.70 \%$ of hortatory orders issued during unified government and $49.30 \%$ issued during divided government. Similar to the expected trends of hortatory orders across time and political party, the expectation here is that politics should not play much of a role. Hortatory orders are used to collect information and their issuance should remain relatively stable during all configurations of government. The remaining types of orders tell a different story.

Other types of executive orders have a higher rate of issuance under divided government. The largest difference occurs with coercive orders, where $56.25 \%$ are issued under divided government and $43.75 \%$ are issued under unified government, a 12.5 percentage point difference. This initial result runs counter to expectations. Coercive orders were expected to occur at a greater rate under unified government. Their level of specificity and forcefulness requires a level of acceptance from Congress, which the president is more likely to have under unified government. However, presidents are more likely to use this tool under divided 
government. One explanation is that presidents are using them to fill in the gaps of legislation passed during divided government to pull outcome closer to the presidents preferred policy preference.

Routine orders are more frequent and occur at higher rate under divided government. This is partly explained by the higher number of routine orders Eisenhower issued because he only governed under unified government for two of his eight years in office. However, 54.92\% of routine orders are issued under divided government and $45.08 \%$ are issued during unified government.

Finally, catalytic orders are issued more frequently under divided government, which aligns with expectations. This type of executive order shifts the creation and implementation of policy to the bureaucracy allowing the president to circumvent a hostile Congress. For instance, President Clinton issued Executive Order 13160 in June of 2000 when he had 256 partisans in the House and Senate combined. This order, focusing on discrimination, allowed the president to mitigate prejudice in federal programs without the support of Congress. Of the catalytic orders issued, $54.80 \%$ are issued under divided government and $45.20 \%$ are issued during unified government, a 9.6 percentage point difference.

Examining unified and divided government provides insights into when this tool is used, however, this simple dichotomy is of limited utility. It does not provide information about the makeup of the House or Senate. It does not provide information about the level of support the president has in each chamber. This weakness is overcome by including a more nuanced measure of presidential support.

Presidential Support: Presidential support comes in three forms - partisan support, ideological support, and public support. Partisan support is defined as a member of Congress 
sharing the same political party as the president. Because the House and Senate require different majorities to pass a bill, or break a filibuster in the Senate, each chamber is analyzed separately. If the application of the analytic framework developed here aligns with previous investigations of executive order use, more executive orders should be issued when less partisans hold seats in the House and Senate, respectively.

In the House the number of presidential partisans across the sample ranges from 143 to 295 with a mean of 218.28 , meeting the required 218 members needed to pass a bill. Figure 3.2 provides four graphs depicting the number of executive orders issued for each type according to the composition of the House with the $\mathrm{X}$ axis showing the number of standard deviations away from the mean. Similar to previous trends, all types except hortatory orders are issued in higher numbers below the mean. The majority of orders fall between one half and one full standard deviation below the mean. The president is most likely to issue an order when the majority is lost and there are between 177 and 197 partisans holding seats in the House. Catalytic orders have the highest incidence of issuance in this range with 151 catalytic orders issued. Routine and coercive orders are also high in this range at 141 and 130, respectively. The numbers are similarly between 198 and 218 partisans. These results suggest that when the president faces an opposition Congress, even at low levels, there is a greater likelihood of taking unilateral action.

The trend of unilateral action is most common just below the mean. When data are analyzed beyond a single standard deviation below the mean, the incidence of executive order use drops drastically. Similar trends occur above the mean, with most executive order actively occurring within a single standard deviation of the mean. This suggests executive orders could be used as a tool to move policy when the president faces moderate levels of opposition or support. At low levels of support, presidents might see executive orders as an ineffective tool and at high 
levels might not need executive orders to achieve the desired policy goals. However, this is only a cautionary tale because most observations of partisan support fall between a standard deviation below and above the mean, creating a greater opportunity for presidents to issue executive orders.

The Senate tells a similar cautionary story. Figure 3.3 provides four graphs depicting the number of executive orders issued for each type according to the composition of the Senate with the $\mathrm{X}$ axis showing the number of standard deviations away from the mean. The range of support starts at a low of 35 and goes up to 68 with a mean of 51 . While 51 constitutes a majority, it is important to keep in mind Senate rules which create an additional veto point because members of the Senate can filibuster and require a 3/5 majority, or 60 members, to end a filibuster. The president does not reach this level of support until a single standard deviation above the mean and the president's party loses the ability to maintain a filibuster just over a single deviation below the mean. With these institutional rules in mind, two expectations are viable. First, more catalytic executive orders should be issued after the president's party loses the ability to maintain the filibuster. Once this occurs policy will favor the opposition party and the president should be more likely to unilaterally pursue policy goals. Second, more coercive executive orders should be issued before the president's party is able to end the opposition's filibuster. Knowing their party cannot break a filibuster should drive the president to act more unilaterally. 
Figure 3.2: Types of Executive Orders Issued by House Partisan Support, 1953-2012
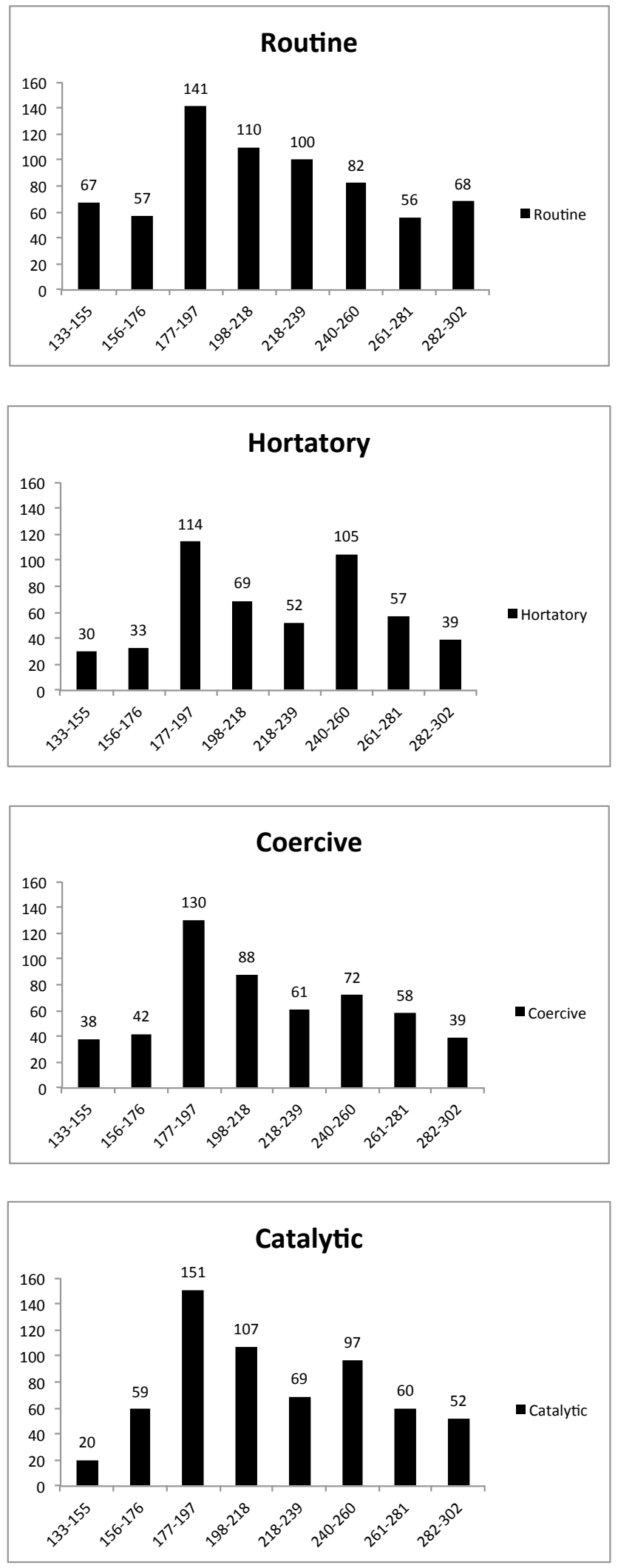
Table 3.3: Types of Executive Orders Issued by Senate Partisan Support, 1953-2012
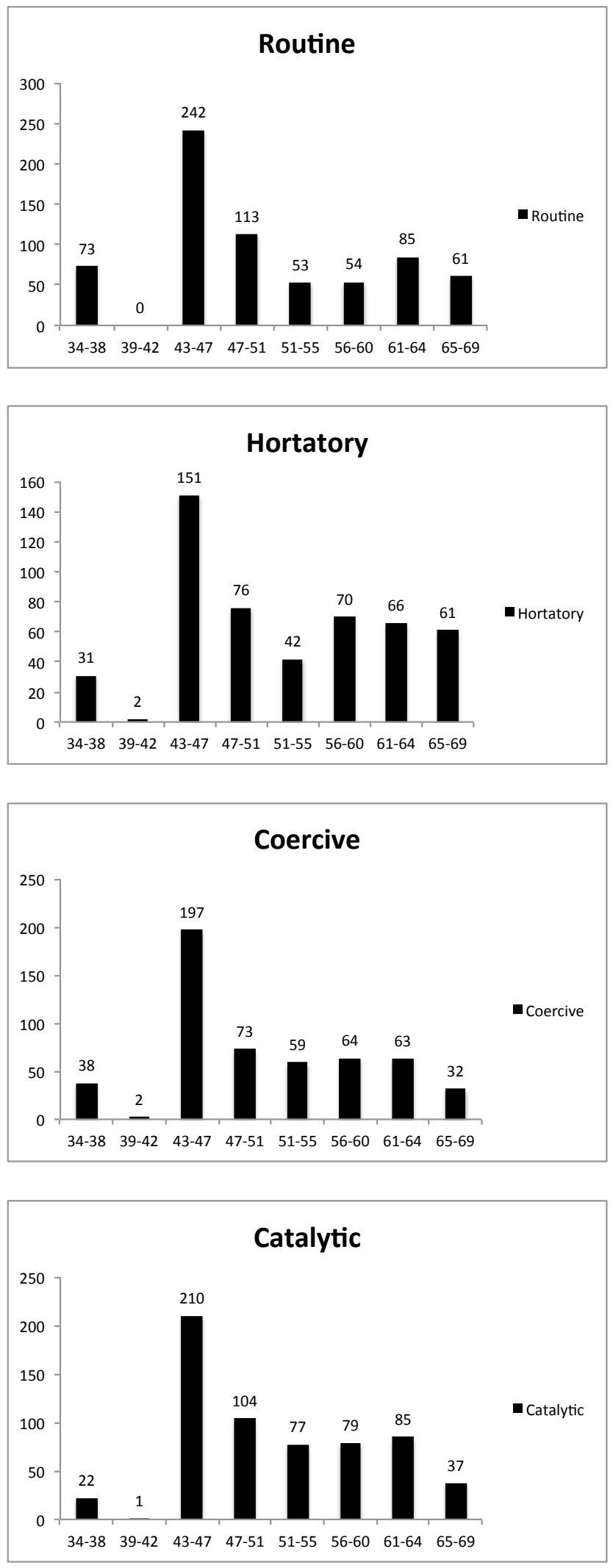
The data show trends that are just the opposite. Executive order activity increases around the veto points but on the opposite side expected. When the president's party can break the veto point, $60+$ partisans, the number of routine and catalytic orders sees a slight increase. Coercive orders remain stable and hortatory orders decrease. The higher number of partisans could be signaling to the president support for unilateral action. However, the number of orders issued is still low compared to those issued when the president loses partisans.

Most executive orders are issued just before the president's party loses the ability to maintain the filibuster, when partisans drop below 40 members. The number of executive orders issued when the president has 43 to 47 partisans is at least double the next highest level of issuance within any type of order. Several explanations are possible here. First, the president is using these tools to support his minority party in the Senate. Instead of Senate partisans continually threatening to filibuster, the president can use executive orders to unilaterally direct policy. Second, examining the House and Senate separately does not mean the other chamber does not have an effect. The counterintuitive trends in the Senate could be a product of dynamics occurring in the House. Finally, similar to the caution expressed when examining House data, the distribution of partisan support provides more opportunities to issue executive orders during this time.

The number of partisans is a key factor to presidential success, but it is not always a reliable predictor because members within parties vary along the ideological continuum. Ideological distance between the president and the mean member of the House and Senate becomes an important component to the president's strategic calculation to issue different types of executive orders. Ideology scores for members of Congress and the president come from the NOMINATE Common Space Score (Poole \& Rosenthal 1991; 1997). The mean of each 
chamber is calculated to determine the distance between the president and each chamber. However, the absolute distance between presidential ideology and the mean member is misleading because it does not provide the direction of the distance. For instance, without accounting for directionality, a president with an ideology score of -0.25 would produce the same distance if the chamber mean was -0.75 or 0.25 . Substantively, these are very different with a liberal president dealing with a liberal chamber in one case and a conservative chamber in another. The directionality measure developed here accounts for this, with positive numbers indicating ideology is moving toward the opposition party and negative numbers indicating ideology is moving toward the president's party. The equation used is as follows:

Ideo_House $=($ President ideology $<0$ than House mean ideology - President ideology $)$ or (President ideology $>0$ than President ideology - House mean ideology)

Ideo_Senate $=($ President ideology $<0$ than Senate mean ideology - President ideology $)$ or (President ideology $>0$ than President ideology - Senate mean ideology)

An interesting phenomenon occurs when applying this directionality measure. The president is always more ideological than the mean in each chamber. This means a liberal president never works with a more liberal House or Senate and a conservative president never works with a more conservative House or Senate. Therefore, all values are positive and small positive values indicate a chamber closer to the president's ideology. The expectation that larger positive values will increase the number of catalytic orders issued and the smaller positive numbers will increase the number of coercive orders.

Figure 3.4 provides a graph for each type of executive order issued with the $\mathrm{X}$ axis measuring standard deviations away from the mean. Ideological distance ranges from 0.093 to 0.818 with a mean of 0.509 . Only hortatory and catalytic orders follow the anticipated trend. Hortatory orders are issued regularly despite changes in ideological distance. There is a 
significant peak occurring just above the mean, with 183 hortatory orders issued. This is likely an artifact of an increased number of observations around them mean, providing greater opportunity to issue more orders. Catalytic orders also follow the anticipated trend. As the ideological distance increases, the president is more likely to issue a catalytic order. This is most acute just above the mean, with 238 catalytic orders issued within a half standard deviation above the mean ideology. The total number of catalytic orders also occur above the mean, with 474 issued compared to 141 below the mean, a difference of 333 orders.

Routine orders are more likely to be issued as ideological distance increases, with 179 more routine orders being issued above the mean. There is a peak when the House ideology becomes close to the president, with the president issuing 167 routine orders. Coercive orders follow a similar pattern, with 132 more coercive orders issued above the mean. There is a peak when the House ideology becomes close to the president, with the president issuing 97 coercive orders, 120 less than the next closest set of observations. This data suggests coercive orders can be used when a friendly House delegates the authority to act or when the opposition holds the House and the president tries to pull policy closer to a more preferred policy.

Tends in the Senate align closer with expectations. Ideological distance in the Senate ranges from 0.054 to 0.0780 with a mean of 0.485 . Similar to the graphs displayed for the House, Figure 3.5 displays the types of executive orders issued with the $\mathrm{X}$ axis measuring standard deviations away from the mean. Routine, hortatory, and catalytic orders align with expectations. Routine orders are more balanced when comparing issuance to Senate ideology. More are issued above the mean, but only 79 more compared to the 179 more above the mean in the House. The trend for hortatory orders remains level with a drop below the mean. This information gathering 
Figure 3.4: Types of Executive Orders Issued by House Ideological Distance, 1953-2012
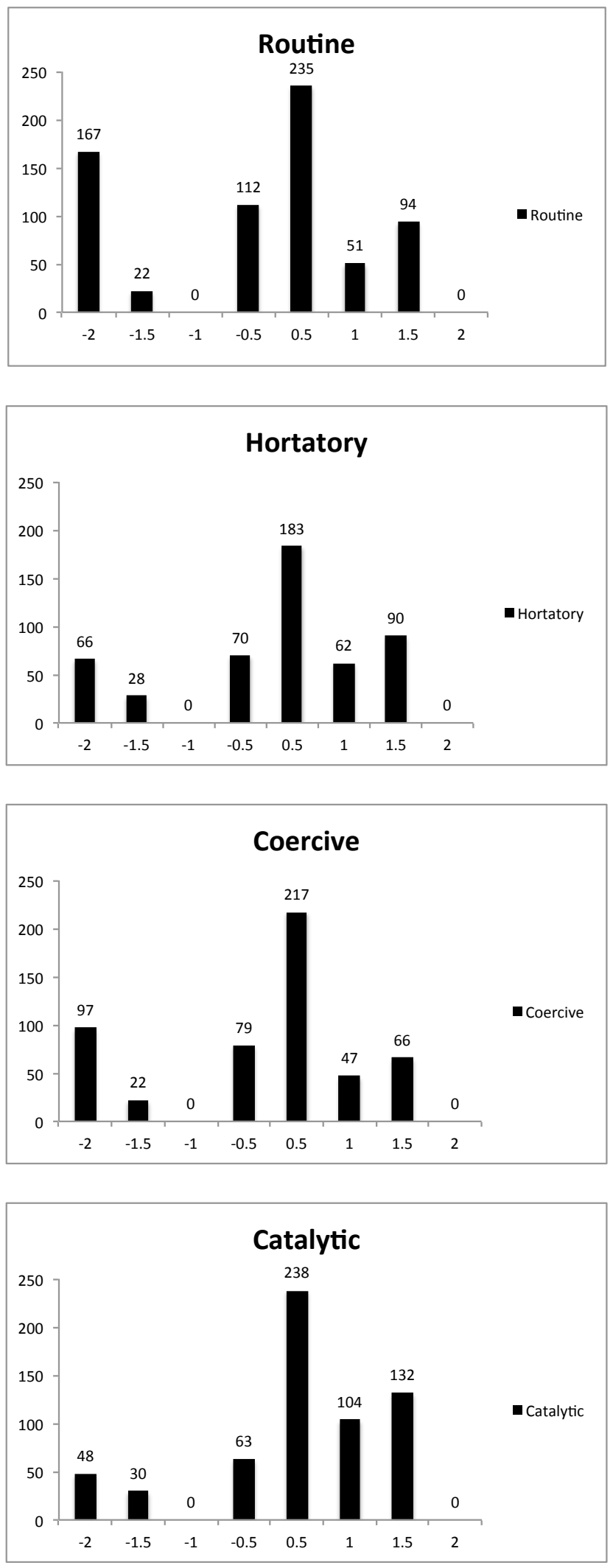
Figure 3.5: Types of Executive Orders Issued by Senate Ideological Distance, 1953-2012
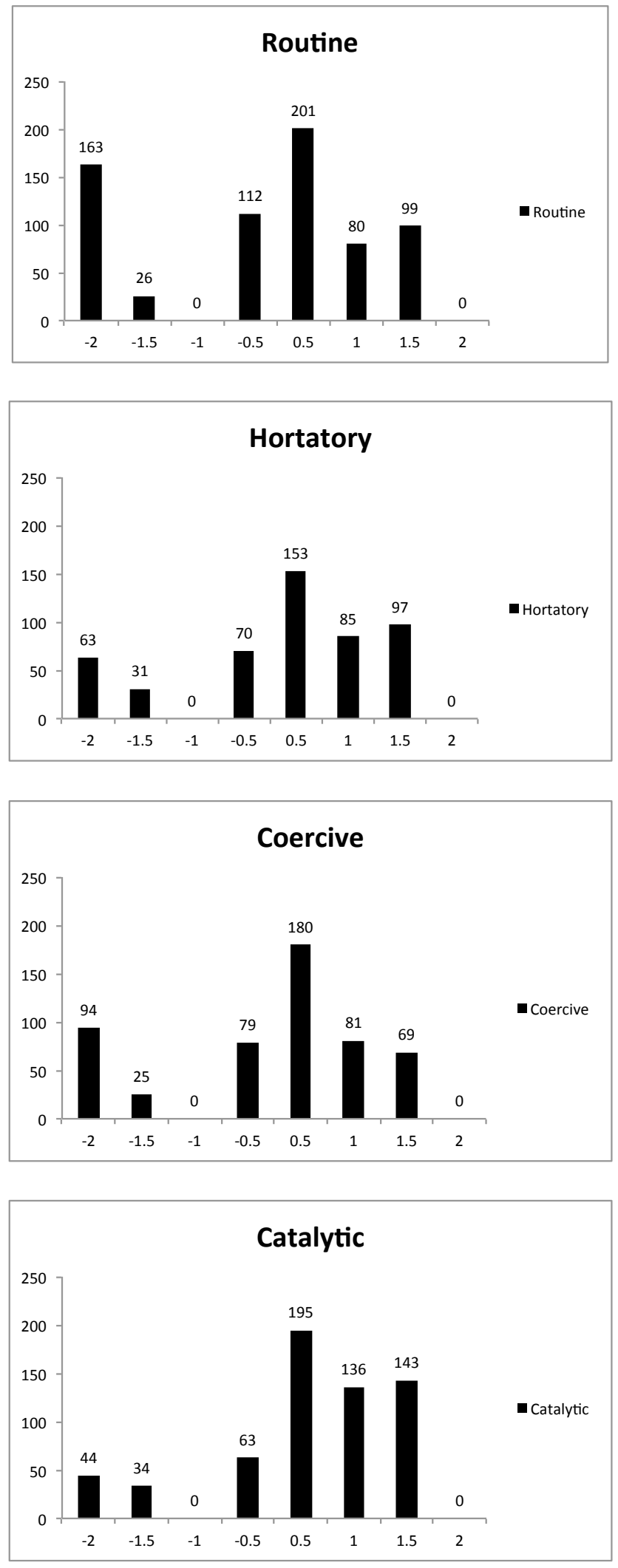
order is used throughout a president's administration regardless of the Senate's ideological composition.

Catalytic orders are issued in higher numbers above the mean, with 333 additional orders issued. This suggests the president is using this tool to circumvent a hostile Senate. However, issuance of catalytic orders does still occur below the mean and shows the president shifts policy creation and execution to the bureaucracy even when there is Senate support.

Coercive orders run counter to the expectation that orders increase when ideology is closer to the president: 132 more are issued above the mean. Similar to trends in the House, the president can use this tool to command bureaucratic action and pull policy closer to a preferred policy when the opposition controls the Senate.

Both partisanship and ideological distance must be interpreted with caution at this point. The next chapter provides more rigorous statistical analysis grounded in strong theoretical arguments. Before moving to more rigorous analysis, the final component of presidential support must be examined - presidential approval.

Presidential Approval: The final component that most argue influences the president's strategic calculus to issue an executive order is presidential approval (Mayer 2001; Howell 2003; Warber 2006; Fine \& Warber 2012). Presidential approval is measured using Gallop's question that asks respondents if they approve of the job the president is doing. Using responses from this question, the three-month average prior to the issuance of the executive order is used to determine the president's popularity. Popularity in the sample ranges from a low of 24, which occurred during Nixon and Watergate, to a high of 86 for George W. Bush following September 11, 2001 with a mean of 54.56. Figure 3.6 displays the use of executive orders by type during 
Figure 3.6: Types of Executive Orders Issued by Presidential Approval Rating, 1953-2012
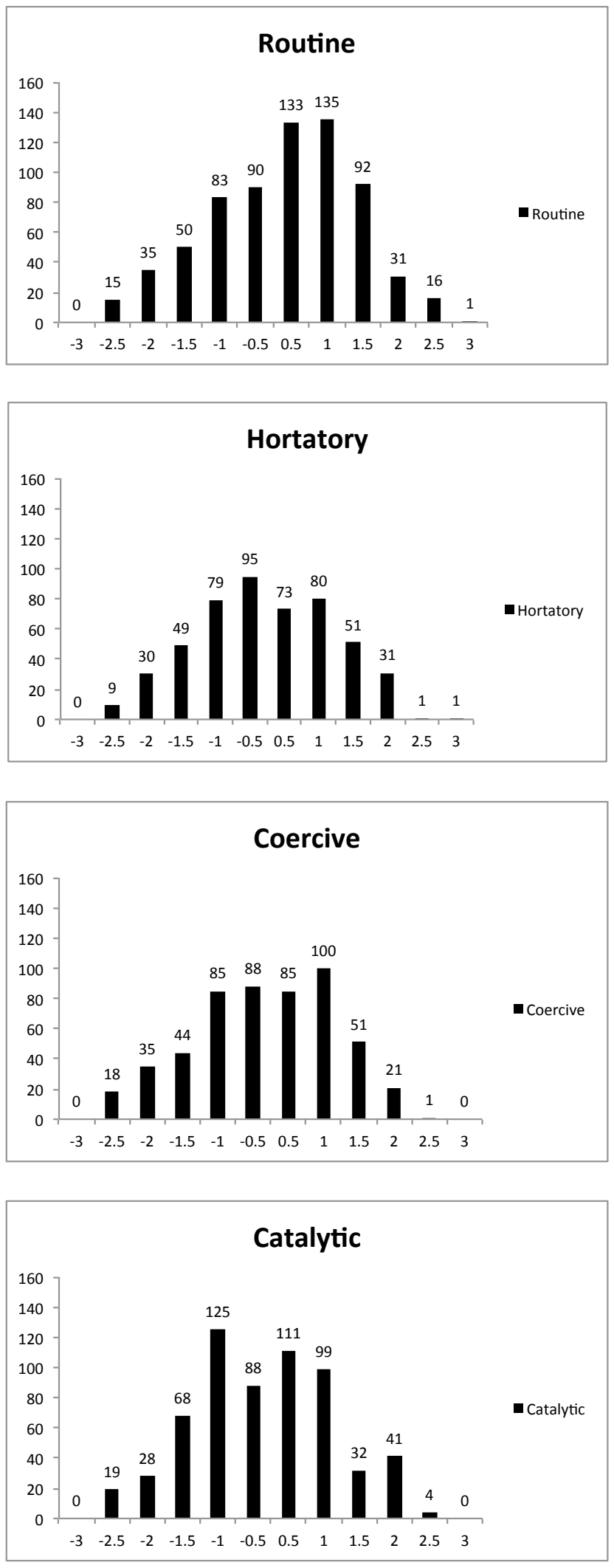
different periods of presidential approval with the $\mathrm{X}$ axis measuring standard deviations away from the mean.

Most activity occurs within one standard deviation of the mean. However, there are interesting differences between the types of executive orders. Routine orders are issued in greater frequency above the mean. Similar to other expectations about routine orders, it was expected presidential approval would not have an effect on when these orders were issued. Their purpose suggests presidents use them throughout their administration, regardless of public approval ratings. It is important to note approval is not the only thing affecting the president's decision to issue an executive order. Intervening variables are likely influencing issuance. The data on approval and routine orders are interesting and future analysis can examine what routine orders are used for.

Hortatory orders have a slight peak below the mean, with more total orders issued below the mean as well. The difference below and above the mean is not large, with 262 issued below the mean and 237 issued above, a difference of 25 orders. This suggests hortatory orders are issued with general consistency despite presidential approval. The slight increase below the mean could be because unpopular presidents use this type of order to gather information and present it to the public. Providing expert information to support presidential policy goals could help influence the public.

Coercive orders are interesting because the peak occurs between 0.5 and 1 standard deviation above the mean, but more are issued below the mean in total. The use of this type across approval ratings shows the versatility of the tool. During times of popularity the president can draw on that support to issue commands, ensuring policy goals are met. As presidential 
approval ratings drop and the president struggles to find support from the public, this tool allows the president to fill policy holes while waiting for approvals ratings to rebound.

Outside of routine orders, the biggest difference above and below the mean occurs in catalytic orders. Both the peak, and majority, of catalytic orders are issued below the mean. Three hundred and twenty-eight orders are issued below the mean and 287 above, a difference of 41 orders. This aligns with trends discussed above for partisan support and ideological distance. In both cases, the president issued more as congressional support declined. The same occurs when the president loses support from the public. This type of executive order gives the president the opportunity to shift the policy process to the bureaucracy and implement policies that align with presidential goals without the support of Congress or the people.

\section{Conclusion}

This chapter provided deep investigation into the content common to each type of executive order, extending our understanding of executive orders by showing presidents use this single tool for a wide range of purposes when faced with varying levels of congressional support and popularity. It reviewed the responses to the questions developed in the previous chapter, elaborating on questions of interest - group creation and advising requirements. Each type of executive order was then examined to determine how response rates within and across each type varied. Once the content of each type was better understood this chapter examined several trends. The first displayed the use of executive order types over time. This initial analysis showed promise because data aligned with previous arguments of executive order use while applying additional rigor and understanding to executive orders. After examining temporal trends, it examined use across administrations, discovering Republicans and Democrats use executive orders differently. Each of the trends analyzed in the first half of the chapter focused on the 
executive order or individual presidents. The trends examined in the second half of this chapter analyzed the president's relationship with Congress and the public.

Congressional support is a key factor in president's strategic calculus when issuing an executive order. The data show executive orders vary as the president gains or loses partisans in the House and Senate and as each chamber moves further away from the president ideologically. Finally, executive order types were analyzed according to the public's approval of the president. Here the data show public approval can influence the type of executive order issued.

Each of the trends discussed above provide clarity to the types of executive orders and when they are issued. However, the analysis is lacking theoretical justifications for when different types of executive orders are issued and statistical rigor to support those justifications. The next chapter explores theories of executive order use and revisits the strategic theory of executive orders, using the data collected here to test the theory. 
Chapter 4

Presidential Policy Tools: The Strategic Use of Executive Orders 
Presidential use of executive orders is an increasingly important and controversial tool in our political system. While executive orders have decreased in absolute numbers, their significance and use as a policy tool has increased (Mayer 1999). However, there is limited research devoted to understanding this tool. Political scientists seek to understand when the president is most likely to issue an order (Howell 2003; Mayer 2001), while legal scholars examine the constitutionality (Rosenberg 1981; Neighbors 1964) and impact of individual orders (Shanley 1983; Wigton 1996). Both fields address important questions about this presidential tool, but approach their analysis in either a macro sense- examining executive orders in the aggregate, which does not provide the nuanced analysis necessary to fully understand their role in our political system; or they study orders at the micro level, examining individual orders, which while beneficial to understanding their role and importance, too often provide only anecdotal evidence. In an effort to add much needed nuance, Mayer (2001), Howell (2003), and Warber (2006) categorize executive orders as significant (Mayer 2001; Howell 2003) or policy relevant (Warber 2006) to more accurately explain how and when the president uses executive orders to unilaterally alter policy.

While an improvement, these studies create only one category of interest by treating executive orders in a binary fashion — as significant or not, policy relevant or not. The framework developed in the previous chapters moves beyond this simple dichotomy and disaggregates executive orders by the amount of bureaucratic discretion and administrative authority they provide agencies. I provide a more nuanced understanding of executive orders to examine when they are used. I argue the president issues executive orders strategically to control or direct bureaucratic behavior depending on the political environment the president is operating within. This chapter proceeds in several parts. First, it reviews the extant literature on executive orders to 
identify gaps. It then develops a theory of the strategic presidency within the newly developed framework. Next, it details the research design to test the theory. Finally, it provides analysis of the results and draws conclusions.

\section{Executive Orders: The Evolution of Presidential Use}

The president's agenda is a complex function of policy cycles and the desire to achieve good policy and an historical legacy (Light 1999,63). Achieving the president's agenda through the traditional legislative process can be difficult the deeper into their term they go, but the president has various tools available to achieve policy goals beyond traditional legislative means. A prominent tool all presidents turn to is executive orders (EOs) (Dodds 2013). Executive orders are extremely attractive because they do not require congressional approval and they carry the full weight of the law, amounting to a soft form of presidential legislation (Morgan 1970,4; Cooper 2002,15; Fleishman \& Aufses 1976,5). They “... are directives issued by the president to officers of the executive branch, requiring them to take an action, stop a certain type of activity, alter policy, change management practices, or accept a delegation or authority under which they will henceforth be responsible for the implementation of law" (Cooper 2014,21). By directing bureaucratic action through the issuance of executive orders, the president can circumvent a hostile Congress or bolster legislation passed by a friendly Congress.

Executive order use evolved as presidents from Washington to Obama issued orders to achieve various goals (Dodds 2013). Administrations following FDR have issued less executive orders annually, but they are now devoted to achieving more substantive goals (Mayer 2001,79). When the president issues significant policy orders is the subject of current scholarly debate. The strategic model provides the most common explanation, where the president issues executive orders to circumvent a hostile Congress (Deering \& Maltzman 1999; Fine \& Warber 2012). 
However, critics argue the president issues more executive orders during times of congressional support (Krause \& Cohen 1997; Mayer 2001). By coding executive orders differently and focusing on different aspects of the presidential-congressional relationship, varying research designs produce alternative findings creating a divide in the field.

Early studies of presidential use of executive orders sought an answer to the question: 'why does the president issue executive orders?' These studies examined aggregate yearly counts of executive orders, suggesting divided government explained the use of executive orders. However, the crude measures of divided government—legislative and executive branches controlled by opposing parties - produce non-significant or weak results, limiting the explanatory power of the models. Critics argued these crude measures of executive orders and inter-branch relations are not sufficient to understanding the nuances of executive orders and only captured one dimension of presidential-congressional relations (Fine \& Warber 2012,263). Light $(1999,27)$ argues political capital, measured by presidential approval and the amount of partisan support the president has in Congress, provides a more complete picture of presidentialcongressional relations. Krause \& Cohen (1997) and Deering \& Maltzman (1999) used a similar measure, offering efforts to predict when the president is likely to issue an executive order. While these studies offered a more nuanced portrait of how capital shapes a president's use of executive orders, critics suggested their annual counts of orders were too crude a measure. Because they treat all executive orders as if they had the same intent, which case studies show is not accurate, these aggregate level studies missed an important strategic aspect of the process.

Building on this critique, Mayer (1999; 2001), in a fashion similar to Mayhew's (2005) categorization of significant legislation, identified significant executive orders as determined by media and academia attention. Agreeing with Mayer's categorization of significant and non- 
significant, but disagreeing with his methodology, Howell (2003) developed an alternative method of coding orders based on their appearance in the appendix of the Congressional Record or their mention in federal court opinions. While an improvement, a problem with this measure of significance is that out of a total of 3,583 orders issued between 1945 and 1998, only twentyseven were classified as significant.

Warber (2006) in reaction to Mayer and Howell, called for developing a more nuanced measure of significance, focusing on the policy content of orders. Using content analysis, along with grants of authority tied to the executive order, he developed three ideal categories; symbolic, routine, and policy, which allowed him to code 5,392 orders according to their intent (Warber 2006,140).

Fine \& Warber (2012) use Warber's (2006) data in an effort to explain how presidentialcongressional relations affect the propensity to issue different types of executive orders. Although Warber (2006) develops three ideal types of executive orders, symbolic and routine orders are collapsed into a single category, essentially leaving policy and non-policy orders. They find support for Deering \& Maltzman's (1999) strategic model, where the president issues policy executive orders to circumvent Congress during periods of low political capital (as indicated by the ideological distance of the median member of Congress from the president). However, the measurement of policy executive orders as “...either departing from the status quo of a specific policy that has already been implemented, or interpreting and implementing legislation that diverts from the original intent of Congress," produces a policy tool the president is not likely to use during periods of high partisan support (Warber 2006,143). When the president has high levels of partisan support in Congress, legislation will be more likely to support the president's agenda and the need for a policy executive order, as defined by Fine \& 
Warber (2012), decreases. I argue these findings are of limited utility because the president uses executive orders to alter policy under conditions of low and high Congressional support.

Like other supporters of the strategic model, Fine \& Warber (2012) argue the president is only using executive orders to alter policy in a significant way under conditions of low political capital. My research argues these findings are faulty and produce a misleading understanding of executive order use. I argue executive orders are a tool the president uses strategically to alter policy at all times, not only when attempting to circumvent Congress. I borrow heavily from Gormley (1989), combining his typology of bureaucratic controls—coercive, catalytic, hortatory—with Warber's (2006) symbolic/routine category to show the president uses different types of executive orders to shape policy depending on the amount of political capital available. The first step in understanding the president's ability to alter policy through executive orders is by focusing attention on an important question that has been largely overlooked: How are executive orders used?

My answer, in brief, is that executive orders are used as bureaucratic controls to shape agency routine. Bureaucratic controls are an important tool principals use to ensure agent actions conform to political intent (Gormley 1989). In a response to the growing bureaucratic apparatus following the New Deal, Gormley categorized bureaucratic controls according to the amount of discretion and authority agencies have in their response to outside requests. Some controls are more coercive and have more muscle behind them, reducing agency discretion and forcing them to act in a highly restrictive manner. Other controls are catalytic and akin to prayers, where principals raise the consciousness of an issue but do not specify a mandatory solution (Gormley 1989,12-13). The president is one actor among many that uses bureaucratic controls in an attempt to alter agency routine. Unlike members of Congress and organized interests who use 
bureaucratic controls, the president is the leader of the executive branch and requires special attention. While the president has many tools to control agencies, executive orders are the most authoritative (Cooper 2014).

Many acknowledge a key function of executive orders is their interaction with the bureaucracy, but, as shown above, do not incorporate the bureaucracy into their analysis. Executive orders are, by definition, a tool of the president used to influence the bureaucracy (Cooper 2014,21). Borrowing from Gormley's (1989) work on efforts to alter bureaucratic routine, I examine executive orders as bureaucratic controls, classifying orders as coercive, hortatory, catalytic, and routine. While the complete typology is developed and explored in previous chapters a brief review follows. Coercive orders constrain agencies, requiring them to take specific actions or adhere to certain rules and regulations. Conversely, catalytic orders give agencies the discretion to interpret the order and develop specific policies to carry out the president's agenda. Hortatory orders fall between coercive and catalytic. They give the bureaucracy the autonomy to utilize expert knowledge in agencies and develop policy recommendations, but the president oversees their actions. Finally, routine orders are used for ministerial business or can be used for a symbolic function and promote American values through something like the creation of an award or national day of observance (Warber 2006,141). Before being able to answer important questions of causality, the purpose of executive orders and their interaction with bureaucracy must be understood.

\section{Executive Orders: The Right Tool for the Job}

A key function of this project is to develop the means of classifying executive orders as coercive, hortatory, catalytic, and routine. According to Mayer $(2001,85)$ and Warber $(2006,140)$, easily placing orders into specific categories is difficult. It is a subjective process 
and in part depends on the observer. Although the concepts of discretion and authority are not mutually exclusive, I separate them conceptually to better understand how executive orders are used. Discretionary aspects focus on the ability to interpret the order and act without oversight while aspects of authority focus on the ability of agencies to control the implementation process. I use examples to highlight executive orders that fall in ideal categories.

Coercive orders are what most commonly come to mind when thinking about executive orders. They are self-executing commands, where the order leads to “...immediate action translating presidential words into the desired outcome" (Mayer 2001,29). When the president issues a coercive order, agencies have minimal discretion. Explicit details or responsibilities for agency action are articulated in the order. Authority is limited in the sense agencies must carry out the prescribed functions of the executive order, however agencies can exercise an increased amount of authority in that area. A coercive order consists of low levels of discretion and high levels of authority. For instance, in EO\# 12264: Export of Banned or Significantly Restricted Substances the Carter White House explicitly states which substances are banned or significantly restricted and then turns to specific methods of controlling those substances. In this case, President Carter used an executive order to articulate explicit rules and regulations agencies must follow.

Catalytic orders consist of high levels of discretion and high levels of authority. They are less explicit than coercive orders, providing agencies greater discretion during implementation and the authority to implement policies across agencies. These orders are more akin to bureaucratic agenda setting. When President George W. Bush issued EO\# 13212: Actions to Expedite Energy-Related Projects he charged agencies to "take appropriate actions, to the extent consistent with applicable law, to expedite projects that will increase the production, 
transmission, or conservation of energy." President Bush did not command explicit action in this example. Instead, the use of a catalytic order provided him a tool to raise agency consciousness and allow individual agencies the discretion to tailor the necessary steps to achieve an expedited process and then have the authority to implement it.

Hortatory orders are somewhere between coercive and catalytic and consist of high levels of discretion with low grants of authority. Commonly, these orders are advisory in nature and are used to gather information. President Kennedy issued EO\# 10934: Establishing the Administrative Conference of the United States in April 1961. The order established an investigatory council tasked with advising President Kennedy on ways to make the bureaucracy more efficient. Agencies are able to steer policy by advising the president but do not have the same freedom to implement policies they receive under catalytic orders.

Finally, routine orders are low in discretion and authority. They generally do not alter bureaucratic routine in any significant way. For instance, President Obama issued EO\# 13657: Changing the Name of the National Security Staff to the National Security Council Staff. This order changed the name of the National Security Staff but did not alter its functions in any substantive way.

This coding scheme provides a more nuanced view of executive orders, providing valuable insights for understanding this presidential tool. First, it adds to current studies through an examination of what executive orders actually do via a content analysis that reveals how the president uses them to shape bureaucratic action. Second, it allows me to revisit the strategic model developed by Deering \& Maltzman (1999). Although recent studies find support for the strategic model, I argue it is one-sided and allows the president to act strategically only under conditions of low congressional support. My model treats executive orders as a tool with 
multiple purposes that the president can use strategically during times of high and low levels of congressional support.

\section{The Strategic President Revisited}

As stated above, when this presidential tool is used consumes most scholarly debate. The most accepted explanation is the strategic model proposed by Deering \& Maltzman (1999) and

confirmed by Fine \& Warber (2012). The strategic model suggests the president issues executive orders to circumvent Congress when they present roadblocks to the president's agenda. Critics argue the president issues more executive orders during times of high congressional support, either to bolster legislation or because Congress supports unilateral action (Gleiber \& Shull 1992; Krause \& Cohen 1997; Moe \& Howell 1999). This project seeks to empirically settle this debate by applying the bureaucratic controls framework to presidential-congressional relations. Applying my coding scheme allows me to revisit the strategic presidency theory of executive orders. I argue as the president's relationship with Congress varies, different types of orders are used. I borrow from Light's (1999) conception of presidential political capital, arguing the president's relationship with Congress is a function of partisan seats in the House and Senate, ideological distance from the mean member of Congress, and public approval.

When to issue an executive order: the current debate: Scholarly debate centers on when the president issues an executive order. A wide range of variables influence the president's propensity to issue an order, from presidential ideology to how far along in the administration the president is. While each impacts the presidency in some way, the majority of explanations involve variations in president's relationship with Congress.

The most commonly accepted explanation of executive order use is the strategic model proposed by Deering \& Maltzman (1999). The president is a strategic actor that must work with 
Congress to achieve his agenda. However, the president cannot always achieve his preferred outcome in the legislative arena. When faced with congressional roadblocks, the president can go-it-alone by issuing an executive order. Roadblocks are most common during times of divided government. However, this dichotomy is crude and produces negligible results, leading to a shift that mirrors Light's (1999) conception of presidential political capital. This includes the percentage of partisan forces in House and Senate, the ideological distance between the president and mean member in each chamber, and presidential approval rating. Using annual counts of executive orders, Deering \& Maltzman (1999) find an inverse effect on the issuance of executive orders. As the president loses partisans in the Senate, the ideological distance between members in both chambers grows, and public support falls, the president issues an increased number of executive orders.

While Deering \& Maltzman's (1999) findings support the strategic model, Fine \& Warber (2012) find fault with annual counts of executive orders because it treats all orders with equal weight. Instead, they rely on Warber's (2006) coding of executive orders into policy and routine/symbolic. Their findings yield results supporting Deering \& Maltzman's (1999) strategic model. They find policy relevant executive orders are inversely related to the ideological distance of the median member in the House and Senate.

Although the strategic model makes sense intuitively, some find a greater propensity for issuance under times of unified government (Mayer 2001; Howell 2003). Gleiber \& Shull (1992) argue for a presidential influence model. The president issues executive orders under unified government to bolster congressional action he agrees with, using this tool to work in tandem with Congress and influence the final outcome of legislation. Krause \& Cohen (1997) agree, arguing influencing legislation is more beneficial for the president in the long run because circumventing 
Congress via executive order makes the president look weak. Using annual counts of executive orders and partisan forces in Congress, Krause \& Cohen (1997) find the president issues an additional order for every ten seats gained in the House or two seats gained in the Senate.

Moe \& Howell (1999) build on the influence model, identifying times when it is beneficial for Congress to allow the president to act via executive order. For instance, when the president has strong partisan forces in Congress, policy goals are more likely to align and it can be more efficient to support unilaterally presidential action. It allows Congress to avoid making conflictual decisions and allows the president to fully take advantage of agency expertise in complex policy areas.

Both the strategic model and the influence model provide viable explanations for the use of this presidential tool. However, current explanations rely on a binary measurement of executive orders--significant or non-significant, policy relevant or non-policy relevant. This limitation leads researchers to find a greater propensity to issue executive orders under periods of high or low congressional support. These are unsatisfactory explanations for such a powerful presidential tool. The application of the bureaucratic controls framework allows for the development of a theory to unify the strategic and influence model into a new strategic model of executive order use.

The New Strategic President: Executive orders are issued throughout a president's term in office. Regardless of the composition of Congress, the president turns to executive orders to achieve policy goals (Dodds 2013). As noted above, current theories suggest the president only acts strategically half the time. Depending on the research design, scholars argue the president issues more orders under times of divided government while others find more are issued under unified government. I argue executive orders are a tool with multiple purposes and the president 
uses this tool strategically to achieve different goals.

In support of Deering \& Maltzman's (1999) strategic model, I suggest the president will issue more catalytic orders as presidential capital decreases. When capital decreases, the president will find it more difficult to pass his agenda through traditional legislative means. When the president is faced with congressional challenges, he can turn to executive orders. Under these circumstances, catalytic orders are the appropriate tool for the job. Unlike coercive orders, they do not command explicit bureaucratic actions. Instead, they allow agencies to develop and implement policy under the general guidance of a politically appointed principal that reflects presidential preferences (Huber \& Shipman 2012). The lack of explicit controls reduces the ability of Congress to point to specific language as a presidential abuse of power. ${ }^{4}$ Instead, it shifts the burden of action onto Congress. Congress must spend resources conducting investigations beyond the specific text of an executive order. For the strategic president, the catalytic order becomes the appropriate type of executive order in an attempt to circumvent Congress. Therefore, the first set of hypotheses are:

H1a: Presidents will issue more catalytic executive orders when their party controls fewer seats in the House

H1b: Presidents will issue more catalytic executive orders when their party controls fewer seats in the Senate.

H2a: Presidents will issue more catalytic executive orders as their ideological distance from the mean member of the House grows.

H2b: Presidents will issue more catalytic executive orders as their ideological distance from the mean member of the Senate grows.

\footnotetext{
${ }^{4}$ While the theory discusses the president's relationship with Congress, hypotheses test the president's relationship with each chamber. The theoretical argument for when the president is likely to issue an executive order is the same for both chambers. The House and Senate are measured and tested separately to isolate the institutional influences of each chamber.
} 
In support of the influence model (Gleiber \& Shull 1992), I suggest the president will issue more coercive orders as presidential capital increases. There are several reasons coercive orders are the appropriate tool under these conditions. First, since the president has political support in Congress, there is less of a risk of congressional blowback, allowing him to use more explicit controls. The president can also use coercive orders to bolster pieces of legislation, working in tandem with Congress. Both the majority and minority party benefit from allowing unilateral presidential action. The majority party is able to achieve policy goals congruent with their agenda without spending the political capital required by traditional legislative means. The minority party avoids a public political battle with a powerful president and by moving policy through executive order, it ensures the policy will not be too far outside the gridlock zone (Krehbiel 1998). Finally, it allows for the possibility to reverse the policy if the minority party takes control of the White House in the future. Therefore, the second set of hypotheses are:

H3a: The president will issue more coercive executive orders when their party controls more seats in the House.

H3b: The president will issue more coercive executive orders when their party controls more seats in the Senate.

H4a: The president will issue more coercive executive orders as their ideological distance from the mean member of the House decreases.

H4b: The president will issue more coercive executive orders as their ideological distance from the mean member of the Senate decreases. 


\section{Testing for the New Strategic President: Research Design}

Data-Executive Orders: Executive order data comes from the American Presidency Project. I collect all executive orders from 1953 to 2012, covering administration from President Eisenhower to Obama. FDR and Truman are excluded from the sample for two reasons. First, it is consistent with the literature (Krause \& Cohen 1997; Deering \& Maltzman 1999; Howell 2003). Second, FDR and Truman were instrumental in expanding the office of the president and used executive orders to achieve that goal, with FDR issuing 3,734 orders alone and Truman issuing 899. Presidents since have built upon that legacy but none have used executive orders in such an expansive role, so FDR is considered by most to be an outlier. Excluding President Roosevelt and Truman leaves 3,199 executive orders issued between 1953 and 2012.

The Dependent Variable: The dependent variable is the type of order issued-routine, coercive, hortatory, catalytic. Orders are coded through text analysis. Each order is read and questions are answered according to the systematic framework developed in the previous chapters. According to the answers of these questions, each order will receive a point value to determine which category the order falls in. Given the four possible values of the dependent variable, testing requires a multinomial logit model. The model is appropriate because the dependent variable has non-ordered categorical values. The multinomial logit allows for the estimation of the relative probability of outcomes to a base outcome. The base outcome used in this analysis is routine orders. Routine orders are used because multinomial logit modeling techniques use the most frequent category observed as the base.

Independent variables: The key explanatory variables adapt Light's (1999) conception of presidential political capital. This involves three separate variables--partisan forces, ideological congruence, and public approval. House_partisans measures the president's share of partisans in 
the House of Representatives. Senate_partisans measures the president's share of partisans in the Senate. A partisan is defined a member of Congress sharing the president's party and data are gathered from the House and Senate websites. Ideo_House and Ideo_Senate are measures that calculate the direction and ideological distance of the president to the mean member of each chamber. Directionality is important because it better explains the relationship of the president with each chamber. For instance, without accounting for directionality, a president with an ideology score of -0.25 would produce the same distance if the chamber mean was -0.75 or 0.25 . Substantively, these are very different with a liberal president dealing with a liberal chamber in one case and a conservative chamber in another. The directionality measure developed here accounts for this, with positive numbers indicating ideology is moving toward the opposition party and negative numbers indicating ideology is moving toward the president's party. Ideology is measured according to DW-Nominate scores found at voteview.com.

According to Light (1999), part of presidential capital is the mandate the president enters office with. The mandate is generally defined by the margin of victory the president has during the election. The issue with using this measure is that mandates do not last. The public's opinion of the president ebbs and flows over time. Therefore, the president's approval rating is used to measure public favor. This measure will capture the president's initial mandate from the public by producing high approval ratings immediately following the election. This measure also allows the mandate to fade. Approval is measured as the president's average approval in the three months prior to the issuance of the executive order. This data is gathered from Gallup.

Beyond the three variables used to tap into presidential political capital, several controls are added. Democrat_pres is a dichotomous variable that measures the party of the issuing president where Republicans are coded as 0 and Democrats are coded as 1 . Following the 
analysis in Chapter 2, Foreign_affairs and War are likely to impact the type of executive order issued. The Agenda's Project determines which executive orders are considered foreign and domestic policy. I apply their coding to my sample. I code War according the Correlates of War data and definition of a war (Singer \& Small 1966). ${ }^{5}$

Time is also an important factor driving presidential action. The Honeymoon measures executive orders issued between inauguration and the end of April, approximately the first three months of the first term in office. ${ }^{6}$ Observations falling in this time period take on a value of 1 and otherwise 0.End_of_term is the last three months of the president's time in office. ${ }^{7}$

Observations falling in this time period take on a value of 1 and otherwise 0. Election_year is an executive order issued between January 1 and the first Tuesday in November during a presidential election year. Observations falling in this time period take on a value of 1 and otherwise 0.Lame_Duck measures the time between the end of an election when the incumbent is leaving the White House and when the president elect takes office. Observations falling in this time period take on a value of 1 and otherwise 0 . Take_over measures executive orders issued between inauguration and the end of April when the opposition party takes over the White House from the incumbent. Observations falling in this time period take on a value of 1 and otherwise 0.

\section{Results}

The full results from the multinomial $\mathrm{T}$ model are provided in Table 4.1. Coefficients can be interpreted for comparison across executive order types but the substantive impacts cannot be interpreted directly. For instance, the positive and significant coefficient for senate_partisans

\footnotetext{
${ }^{5}$ The Correlates of War Project is continually updated and can be found at correlatesofwar.org.

${ }^{6}$ The honeymoon period includes President Johnson and Ford's first three months in office.

${ }^{7}$ President Kennedy and Nixon do not have end of term measures.
} 
under hortatory orders indicates as the number of Senate partisans increases, it is more likely the president will issue a hortatory order compared to a routine order, given that an executive order is issued. Conversely, the negative and significant coefficient for house_partisans under hortatory orders indicates as the number of House partisans increases, it is more likely the president will issue a routine order comparted to a hortatory order, given that an executive order is issued. This interpretation says nothing about the magnitude of the effect as partisanship levels increase or decrease in the chambers. To determine the substantive effect of these results, predicted probabilities are calculated using Clarify in Stata.

Before turning to an examination of the individual hypotheses, it is important to note that issuance differs by presidential party. Table 4.2 shows the difference between Republicans and Democrats. As expected the probability of issuing a hortatory order compared to a routine order is fairly balanced between Republicans and Democrats at $22.28 \%$ and $24.54 \%$, respectively. Republicans are more likely to issue coercive orders at $21.82 \%$. Democrats are 4.78 percentage points lower at $17.04 \%$. Conversely, there is a greater probability that Democrats will issue a catalytic order compared to a routine order at $33.90 \%$. The difference between Democrats and Republicans is approximately 10 percentage points for this type of order, with Republicans likely to issue a catalytic order $23.84 \%$ of the time. This aligns with the descriptive data and expectations developed in the previous chapter. Republicans are more likely to use direct control when issuing and executive order and Democrats are more likely to shift policy creation to the bureaucracy.

The following review of the results will examine the predicted probabilities of significant variables. Each set of variables is reviewed for Republican presidents and Democratic presidents. There will be two tables for each key variable with Table Xa examining Republican presidents 
and Table $\mathrm{Xb}$ examining Democratic presidents. The base model used to calculate predicted probabilities holds House partisans at 218 (the true House mean is 218.28), Senate partisans at 51 (the true Senate mean is 51.59), popularity at the mean (54.97), and all other dichotomous variables at their mode. This includes democrat_pres which has a modal value of 0 , indicating Republicans issued more executive orders.

The hypotheses developed focus on the issuance of catalytic and coercive executive orders and produce mixed results. Ideology does not influence executive order use as expected. None of the measures developed produce significant results for any type of executive order. Therefore, $\boldsymbol{H} 2 \boldsymbol{a}, \mathrm{H} 2 \boldsymbol{b}, \mathrm{H} 4 \boldsymbol{a}$, and $\boldsymbol{H} 4 \boldsymbol{b}$ are rejected. As the mean ideological distance of the House and Senate move away from the president, it does not influence executive order use. There are several explanations that could explain the null results. First, the changing nature of ideology over the course of the sample could be biasing the results. The same Nominate measure is used from 1953 to 2012, but what liberal and conservative means has changed during that time. The ideology measure captured early in the sample could mean something different later in the sample.

Second, null results could be a product of the Nominate measure. Presidential ideology is determined by treating the president as a voting member of Congress when the president takes a position on an issue. This positions the president within the construct of congressional ideology and not independent of the measure. The measure provides an approximation of the ideological distance between the president and the mean in each chamber, but it might not be accurate because presidential ideology is not developed independently of congressional ideology. 
Table 4.1: Predicting Executive Order Type, 1953-2012

\begin{tabular}{|c|c|c|c|}
\hline & Hortatory & Coercive & Catalytic \\
\hline House_Partisans & $\begin{array}{c}-0.006^{*} \\
(0.003)\end{array}$ & $\begin{array}{l}-0.002 \\
(0.003)\end{array}$ & $\begin{array}{c}-0.008 * * \\
(0.003)\end{array}$ \\
\hline Senate_Partisans & $\begin{array}{l}0.042 * * \\
(0.0140\end{array}$ & $\begin{array}{c}0.016 \\
(0.014)\end{array}$ & $\begin{array}{c}0.028 * * \\
(0.013)\end{array}$ \\
\hline House_Ideo & $\begin{array}{l}-1.016 \\
(2.046)\end{array}$ & $\begin{array}{l}-1.514 \\
(2.077)\end{array}$ & $\begin{array}{c}-0.614 \\
(1.866)\end{array}$ \\
\hline Senate_Ideo & $\begin{array}{c}1.888 \\
(2.084)\end{array}$ & $\begin{array}{c}1.361 \\
(2.101)\end{array}$ & $\begin{array}{c}2.370 \\
(1.918)\end{array}$ \\
\hline Popularity & $\begin{array}{c}-0.011 * * \\
(0.005)\end{array}$ & $\begin{array}{c}-0.018 * * \\
(0.005)\end{array}$ & $\begin{array}{c}-0.009 * \\
(0.005)\end{array}$ \\
\hline Democrat_pres & $\begin{array}{l}0.365^{*} \\
(0.215)\end{array}$ & $\begin{array}{c}0.021 \\
(0.218)\end{array}$ & $\begin{array}{c}0.621 * * \\
(0.195)\end{array}$ \\
\hline Foreign_affairs & $\begin{array}{c}-1.261 * * * \\
(0.204)\end{array}$ & $\begin{array}{c}0.583 * * * \\
(0.139)\end{array}$ & $\begin{array}{c}0.227 \\
(0.140)\end{array}$ \\
\hline War & $\begin{array}{c}-0.472 * * \\
(0.156)\end{array}$ & $\begin{array}{l}-0.201 \\
(0.145)\end{array}$ & $\begin{array}{c}-0.412 * * * \\
(0.480)\end{array}$ \\
\hline Honeymoon & $\begin{array}{c}0.555 \\
(0.386)\end{array}$ & $\begin{array}{l}-0.035 \\
(0.411)\end{array}$ & $\begin{array}{l}-0.412 \\
(0.480)\end{array}$ \\
\hline End_of_term & $\begin{array}{c}14.825 \\
(1071.377)\end{array}$ & $\begin{array}{c}0.048 \\
(1644.222)\end{array}$ & $\begin{array}{c}15.550 \\
(1071.377)\end{array}$ \\
\hline Election_year & $\begin{array}{c}0.407 * * \\
(0.160)\end{array}$ & $\begin{array}{c}0.086 \\
(0.161)\end{array}$ & $\begin{array}{l}-0.156 \\
(0.158)\end{array}$ \\
\hline Lame_duck & $\begin{array}{c}-14.418 \\
(1071.377)\end{array}$ & $\begin{array}{c}0.086 \\
(1644.222)\end{array}$ & $\begin{array}{c}-15.686 \\
(1071.377)\end{array}$ \\
\hline Take_over & $\begin{array}{l}-0.139 \\
(0.488)\end{array}$ & $\begin{array}{c}0.218 \\
(0.517)\end{array}$ & $\begin{array}{c}0.278 \\
(0.575)\end{array}$ \\
\hline Constant & $\begin{array}{l}-0.975 \\
(0.624)\end{array}$ & $\begin{array}{c}0.447 \\
(0.611)\end{array}$ & $\begin{array}{l}-0.286 \\
(0.582)\end{array}$ \\
\hline
\end{tabular}

Observations $=2323$

Base Category - Routine 
Table 4.2: Predicted Probabilities of Executive Order Type by Presidential Party, 1953-2012

\begin{tabular}{lrr} 
& Republican & Democrat \\
\cline { 2 - 3 } Routine & $32.06 \%$ & $24.51 \%$ \\
Hortatory & $22.28 \%$ & $24.54 \%$ \\
Coercive & $21.82 \%$ & $17.04 \%$ \\
\hline Catalytic & $23.84 \%$ & $33.90 \%$
\end{tabular}

This measurement issue leads to the final possible reason for the null results. Once directionality is accounted for in measure, the president is always more ideological than their party. Under periods of unified government, a liberal president never works with a more liberal House or Senate. According to the measurements developed where high negative numbers are good for the president, and high positive numbers are bad, the ideology measures never receive a negative score. The mean for both chambers hoovers around 0.50 . According to the data, the president would have to fall below -0.50 on the Nominate's scale that ranges from -1 to 1 in order to be working with a chamber whose ideology leans slightly in the president's favor.

While the ideology measure does not produce significant results, the data do pose new questions that warrant investigation. Specifically, the implications of this measure for future studies of presidential-congressional relations. While this measure of presidential ideology is the most accepted, does it represent an accurate and rigorous measure of presidential ideology? By using the Congress to construct the president's ideology, it increases the likelihood of Type II errors because the data does not reflect the president's true ideological distance from Congress. 
Table 4.3a: Republican Probabilities of Executive Order Type by House Support, 1953-2012

\begin{tabular}{lc|c|c} 
& \multicolumn{1}{c}{$\begin{array}{c}\text { 143 House } \\
\text { Partisans }\end{array}$} & \multicolumn{1}{c}{$\begin{array}{c}\text { 218 House } \\
\text { Partisans }\end{array}$} & \multicolumn{1}{c}{$\begin{array}{c}\text { 295 House } \\
\text { Partisans }\end{array}$} \\
\cline { 2 - 4 } Routine & $23.20 \%$ & $32.06 \%$ & $41.80 \%$ \\
Hortatory & $25.93 \%$ & $22.28 \%$ & $17.91 \%$ \\
Coercive & $19.04 \%$ & $21.82 \%$ & $23.59 \%$ \\
Catalytic & $31.73 \%$ & $23.84 \%$ & $16.70 \%$
\end{tabular}

Table 4.4b: Democrat Probabilities of Executive Order Type by House Support, 1953-2012

\begin{tabular}{|c|c|c|c|}
\hline & $\begin{array}{c}143 \text { House } \\
\text { Partisans }\end{array}$ & $\begin{array}{c}218 \text { House } \\
\text { Partisans }\end{array}$ & $\begin{array}{c}295 \text { House } \\
\text { Partisans }\end{array}$ \\
\hline Routine & $16.75 \%$ & $24.51 \%$ & $34.05 \%$ \\
\hline Hortatory & $26.86 \%$ & $24.54 \%$ & $21.02 \%$ \\
\hline Coercive & $13.98 \%$ & $17.04 \%$ & $19.63 \%$ \\
\hline Catalytic & $42.42 \%$ & $33.90 \%$ & $25.31 \%$ \\
\hline
\end{tabular}

The measures of partisanship produce mixed results in the House and Senate. Table 4.3a and Table 4.3b show $\mathrm{HIa}$ is confirmed and is significant at the $\mathrm{p}<.05$ level. The president is more likely to issue catalytic orders as levels of partisan support decreases in the House. When a Republican president has enough partisans to get a bill passed in the House there is a $23.84 \%$ probability an executive order issued will be catalytic compared to a routine order. Democrats are approximately 10 percentage points more likely to issue a catalytic when they have 218 partisans in the House. Moving to the minimum of 143 partisans in the House, both parties are more likely to issue a catalytic order. Given an executive order is issued, Republicans have a 
$31.73 \%$ probability of issuing a catalytic order compared to a routine order. Democrats have a $42.42 \%$ probability of issuing a catalytic order at the minimum. This is approximately 7

percentage points higher than the probability at 218 partisan members. The probability of issuing a catalytic order drops by nearly half to a $16.70 \%$ probability for Republicans at maximum levels of support - 295 House partisans. The drop is not as pronounced for Democrats but still drops from $42.42 \%$ to $25.31 \%$, a 17.11 percentage point difference.

Table 4.3a and Table 4.3b also show an increase in coercive executive order use when the president gains partisans. While this aligns with expectations, coercive orders do not reach a level of significance. Therefore, $\boldsymbol{H} \mathbf{3} \boldsymbol{a}$ is rejected because it cannot be said coercive orders are more likely to be issued when the president gains House partisans with statistical confidence.

Hortatory orders do reach significance at the $\mathrm{p}<.05$ level and follow the same pattern as catalytic orders. President are more likely to issue them when they have limited partisan support in Congress. The probability of issuing a hortatory order is only slightly higher under conditions of partisan opposition compared to partisan support. Presidents are likely using this tool against an opposition House to gather expert information in an attempt to make convincing policy arguments and sway opposition members.

The role of partisanship in the Senate produces results that contradict expectations.

Senate_partisans is significant at the $\mathrm{p}<.05$ level but the sign is in the opposite direction, forcing the rejection of $\boldsymbol{H} \boldsymbol{1 b}$. Presidents are not more likely to issue a catalytic order compared to routine order when partisan support in the Senate decreases. ${ }^{8}$ Table 4.4a and Table 4.4b show the opposite effect occurs and presidents issue less catalytic orders as they lose partisan support

\footnotetext{
${ }^{8}$ An increase of catalytic orders occurs when partisan support in the Senate goes up when the House and Senate are examined individually. When combing partisan support in the House and Senate, or using a simple unified and divided government measure, the overall effect is more catalytic orders when partisan support decreases or there is divided government.
} 
in the Senate. The difference between the point to maintain a filibuster and the point to break a filibuster, is not large. When the president has 39 Senate partisans there is a $21.21 \%$ probability a Republican will issue a catalytic order and a $31.30 \%$ probability a Democrat will. When the president's party is able to break a filibuster with 61 Senate partisans, there is a $25.55 \%$ probability a Republican will issue a catalytic order and a 35.30\% probability a Democrat will. Both parties increase approximately 4 percentage points from 39 partisans to 61 partisans.

Table 4.4a: Republican Probabilities of Executive Order Type by Senate Support, 1953-2012

\begin{tabular}{|c|c|c|c|}
\hline & $\begin{array}{l}39 \text { Senate } \\
\text { Partisans }\end{array}$ & $\begin{array}{l}51 \text { Senate } \\
\text { Partisans }\end{array}$ & $\begin{array}{l}61 \text { Senate } \\
\text { Partisans }\end{array}$ \\
\hline Routine & $39.75 \%$ & $32.06 \%$ & $26.05 \%$ \\
\hline Hortatory & $16.61 \%$ & $22.28 \%$ & $27.66 \%$ \\
\hline Coercive & $22.43 \%$ & $21.82 \%$ & $20.74 \%$ \\
\hline Catalytic & $21.21 \%$ & $23.84 \%$ & $25.55 \%$ \\
\hline
\end{tabular}

Table 4.4b: Democrat Probabilities of Executive Order Type by Senate Support, 1953-2012

\begin{tabular}{|c|c|c|c|}
\hline & $\begin{array}{c}39 \text { Senate } \\
\text { Partisans }\end{array}$ & $\begin{array}{l}51 \text { Senate } \\
\text { Partisans }\end{array}$ & $\begin{array}{c}61 \text { Senate } \\
\text { Partisans } \\
\end{array}$ \\
\hline Routine & $31.53 \%$ & $24.51 \%$ & $19.35 \%$ \\
\hline Hortatory & $18.99 \%$ & $24.54 \%$ & $29.61 \%$ \\
\hline Coercive & $18.17 \%$ & $17.04 \%$ & $15.74 \%$ \\
\hline Catalytic & $31.30 \%$ & $33.90 \%$ & $35.30 \%$ \\
\hline
\end{tabular}

The relationship of Senate partisans produces a significant and counterintuitive result but the substantive impact is only 4 percentage points at observations close to the minimum and 
maximum. ${ }^{9}$ While the substantive effect is smaller than the House, the opposite signs in the House and the Senate require further investigation and theoretical development. One explanation is that there is greater variation of partisan support in the House because the entire House faces the electorate every two years. The Senate is more stable with less members facing the electorate every election cycle. While the Senate might influence executive order use, the influence in the House can have a larger impact because members of the House are less known due to electoral turnover, forcing the president to rely on partisanship as a cue for support. In the Senate, members serve for longer terms making member behavior more reliable and reducing the need to use partisanship as short cut for support.

Coercive executive orders have the right sign to support $\boldsymbol{H} \boldsymbol{3} \boldsymbol{b}$, suggesting the president issues more coercive orders when there are more partisans in the Senate, but Senate_partisans does not reach statistical significance, forcing the rejection of $\boldsymbol{H} 3 \boldsymbol{b}$. Hortatory orders are significant at the $\mathrm{p}<.05$ level and show a dramatic increase from 39 to 61 Senate partisans. Both Republicans and Democrats are approximately 11 percentage points more likely to issue a hortatory order at high levels of support. Republicans have a $16.61 \%$ probability at 39 Senate partisans and $27.66 \%$ probability at 61 Senate partisans. Democrats are slightly higher at $18.99 \%$ and $29.61 \%$, respectively. This runs counter to expectations that hortatory orders should not be effected by the president's relationship with the Senate. Hortatory orders were expected to be used consistently and not be influenced by other factors. The higher probability of issuing a hortatory order as Senate partisans increases suggests the president is using this to gather information and inform opposition Senators that could be a deciding vote. When the president has low levels of support in the Senate, it becomes more difficult to get the president's program

\footnotetext{
${ }^{9}$ The range of Senate partisans is 35 to 68 . Thirty-nine and 61 are used because they make substantive sense given the Senate rules for maintaining and breaking a filibuster.
} 
passed. Presidents have to convince more opposition Senators to support a policy. This requires focused attention, reducing the number of information gathering orders the president is likely to issue. Conversely, when presidents have a high level of Senate support, there are fewer opposition members that need to be convinced to pass a policy. This means the president can potentially address multiple policy issues at once.

Table 4.5a: Republican Probabilities by Approval Rating, 1953-2012

\begin{tabular}{lccc} 
& $\begin{array}{c}25 \% \\
\text { Approval } \\
\text { Rating }\end{array}$ & $\begin{array}{c}55 \% \\
\text { Approval } \\
\text { Rating }\end{array}$ & $\begin{array}{c}86 \% \\
\text { Approval } \\
\text { Rating }\end{array}$ \\
\cline { 2 - 4 } Routine & $24.39 \%$ & $32.06 \%$ & $40.88 \%$ \\
Hortatory & $23.28 \%$ & $22.28 \%$ & $20.41 \%$ \\
Coercive & $28.51 \%$ & $21.82 \%$ & $15.84 \%$ \\
Catalytic & $23.83 \%$ & $23.84 \%$ & $22.87 \%$
\end{tabular}

Table 4.5b: Democrat Probabilities by Approval Rating, 1953-2012

\begin{tabular}{lccc} 
& $\begin{array}{c}25 \% \\
\text { Approval } \\
\text { Rating }\end{array}$ & $\begin{array}{c}55 \% \\
\text { Approval } \\
\text { Rating }\end{array}$ & $\begin{array}{c}86 \% \\
\text { Approval } \\
\text { Rating }\end{array}$ \\
\cline { 2 - 4 } Routine & $18.57 \%$ & $24.51 \%$ & $31.69 \%$ \\
Hortatory & $25.53 \%$ & $24.54 \%$ & $22.80 \%$ \\
Coercive & $22.17 \%$ & $17.04 \%$ & $12.54 \%$
\end{tabular}

The hypotheses developed produced mixed results but other interesting findings arise in the results. Presidential approval has a negative coefficient for each type of order and is significant at the $\mathrm{p}<.05$ level for hortatory and coercive orders and significant at the $\mathrm{p}<.10$ level for catalytic 
orders. This indicates as the president's public approval rating increases the likelihood of issuing any type of order, compared to a routine order, decreases. Table 4.5a and Table 4.5b show the predicated probabilities as presidential approval varies for Republicans and Democrats, respectively. Routine orders are more likely when approval ratings are high with other types of orders decreasing. When presidents are popular the necessity of unilateral action is likely to decrease. Having public support can push Congress to be more amenable to presidential policies. Hortatory and Catalytic orders only see decreases of a few percentage points when moving from low levels of approval to high. Coercive orders provide an exception and produce a drop of approximately 12 percentage points for Republicans and 10 points for Democrats. Presidents are unlikely to need this tool as they become more popular because they are able to achieve their legislative program through the traditional policy process. The fact that catalytic orders do not decrease much suggests this remains an important presidential tool. It can be used to direct policy when the president is not popular, forcing unilateral action. However, the results show it can be used when the president is popular as well. When the people approve of the president and trust the president's ability to lead the country, they are more willing to defer to more expansive unilateral action.

Interesting differences arise when the president issues executive orders for domestic and foreign affairs. Table 4.6a and Table 4.6b display the predicted probabilities of domestic and foreign affairs executive orders. Hortatory orders have a negative sign and coercive orders have a positive sign and both are significant at the $\mathrm{p}<.001$ level. The negative sign for hortatory orders indicates a higher probability of domestic affairs orders. The difference is approximately 16.5 percentage points for Republicans and Democrats. While the information gathering process is no more or less important in domestic affairs or foreign affairs, the final product produced by 
information gathering groups is more important in domestic affairs. The production of an official expert report can be used to convince moderates and the opposition of policy. In foreign affairs the president has more latitude to act unilaterally. It is likely information gathering is still occurring but the information is kept confidential and reported directly to the president to make foreign policy decisions.

Table 4.6a: Republican Probabilities by Policy Type, 1953-2012

\begin{tabular}{|c|c|c|}
\hline & $\begin{array}{c}\text { Domestic } \\
\text { Affairs }\end{array}$ & $\begin{array}{c}\text { Foreign } \\
\text { Affairs }\end{array}$ \\
\hline Routine & $32.06 \%$ & $29.86 \%$ \\
\hline Hortatory & $22.28 \%$ & $5.88 \%$ \\
\hline Coercive & $21.82 \%$ & $36.41 \%$ \\
\hline Catalytic & $23.84 \%$ & $27.86 \%$ \\
\hline
\end{tabular}

Table 4.6b: Democrat Probabilities by Policy Type, 1953-2012

\begin{tabular}{lc|c} 
& \multicolumn{1}{c}{$\begin{array}{c}\text { Domestic } \\
\text { Affairs }\end{array}$} & $\begin{array}{c}\text { Foreign } \\
\text { Affairs }\end{array}$ \\
\cline { 2 - 3 } Routine & $24.51 \%$ & $23.45 \%$ \\
Hortatory & $24.54 \%$ & $6.66 \%$ \\
Coercive & $17.04 \%$ & $29.21 \%$ \\
Catalytic & $33.90 \%$ & $40.69 \%$
\end{tabular}

The increased probability of coercive foreign affairs orders aligns with arguments that the president has greater latitude of action in foreign policy. The probability of coercive order increases approximately 13 percentage points for Republicans and Democrats. The president's 
increased sphere of power in foreign policy aligns with the increase of command function of coercive executive orders.

One source of authority for the president's foreign policy power is the commander-in-chief mandate. During times of war the president consolidates power to ensure the efficient management of a conflict. It is expected that the president would issue more coercive orders during times of war, however the data do not produce significant results for coercive orders. It is likely that under war conditions the president does not need to issue commands in the form of executive orders. Instead, orders are issued directly to the Joint Chiefs of Staff and passed down the chain of command. Hortatory and catalytic orders have the expected negative sign, indicating they are less likely to be issued during times of war compared to routine orders. Hortatory orders are significant at the $\mathrm{p}<.001$ level and produce an approximate change of 3.5 percentage points for Republicans and Democrats. Catalytic orders are significant at the $\mathrm{p}<.05$ level and produce an approximate change of 8 percentage points for Republicans and Democrats (see Table 7a and Table 7b).

While there are multiple aspects influencing the president's propensity to issue different types of executive orders, time does not seem to be one of them. The only influence of time occurs during an election year and for hortatory orders. Hortatory orders have a positive sign and are significant at the $\mathrm{p}<.05$ level, indicating they are more likely during an election year compared to routine orders. Election years are a prime time for the president to use hortatory orders. Information can be gathered to inform policy positions used on the campaign trail. The information can be used to help articulate the candidates message and inform voters. It is important to note that the information gathered does not have to be used by the incumbent. Increases occur during all presidential election years, not just when the incumbent is running. 
The president's party will continue to compete for the White House and can take advantage of the information asymmetry the White House commands.

Table 4.7a: Republican Probabilities by War, 1953-2012

\begin{tabular}{|c|c|c|}
\hline & No War & War \\
\hline Routine & $32.06 \%$ & $42.06 \%$ \\
\hline Hortatory & $22.28 \%$ & $18.23 \%$ \\
\hline Coercive & $21.82 \%$ & $23.42 \%$ \\
\hline Catalytic & $23.84 \%$ & $16.29 \%$ \\
\hline
\end{tabular}

Table 4.7b: Democrat Probabilities by War, 1953-2012

\begin{tabular}{|c|c|c|}
\hline & No War & War \\
\hline Routine & $24.51 \%$ & $34.32 \%$ \\
\hline Hortatory & $24.54 \%$ & $21.44 \%$ \\
\hline Coercive & $17.04 \%$ & $19.52 \%$ \\
\hline Catalytic & $33.90 \%$ & $24.72 \%$ \\
\hline
\end{tabular}

\section{Conclusion}

The application of the bureaucratic framework developed here was meant to unify the competing theories of executive order use. Instead of a theory arguing for presidential influence where more executive orders are issued under unified government and a separate theory arguing the president circumvents a hostile Congress, examining executive orders through a bureaucratic 
lens was meant to show both arguments are correct and different types of executive orders are issued depending on the institutional context presidents find themselves in. While unification was not accomplished, this new framework does bear fruit and provides invaluable insight and nuance to executive order use.

The institutional relationship between Congress and president produces mixed results. Partisan support does influence the type of order issued, but there is variation by type and chamber. Of special interest is the role of coercive and catalytic orders. Coercive orders do not produce statistically significant results and when they are used requires further examination. Catalytic orders do produce significant results, but the probability of one being issued is different in the House and Senate. When the president loses partisans in the House there is a greater likelihood of a catalytic order being issued. Conversely, as the president gains partisans in the Senate there is a greater likelihood of a catalytic order being issued. While these results contradict each other, the substantive effect on the probability of catalytic orders issued is much larger in the House than the Senate. More research needs to be done to explore this discrepancy but the larger effect in the House suggests the president might allow partisan identification to have a larger influence on his strategic calculation when deciding what type of executive order to issue. This is likely because the House faces the electorate more frequently and there is a higher level of turnover in the lower chamber. In the Senate, less members face election every two years and the longer terms create stable preferences the president can more easily judge.

Although the effect is opposite in the House and the Senate, the larger effect in the House confirms the common theory of executive order use that suggests the president uses executive orders to circumvent Congress. Confirming this theory through the framework developed here is valuable because it shows how the president circumventing Congress. The president can provide 
general policy direction to bureaucratic agents and grant them the discretion to develop concrete policy and the authority to implement it.

This research effectively shows executive orders are a single tool the president can use for multiple purposes. The more nuanced examination here provides an important piece to the puzzle of executive order use. It moves beyond examining when they are used and focuses first on how they are used. There are significant benefits to better understanding the intricacies of this tool. It shows the true scope of this tool and identifies avenues to examine the mechanisms of implementation. During a time when there are claims of executive overreach, understanding how executive orders are used will allow actors to identify and respond to specific types of executive orders that the public believes broach executive authority. A deeper investigation of each type of order and when they are used will also provide greater understanding to the use of this tool. Additionally, each type of executive order provides bureaucratic agents different amounts of discretion and authority. Their response to these orders would provide an important next step. Despite the president's use of executive orders, the field's understanding of them is fairly limited. The theoretical framework developed here expands our understanding and should present scholars novel ways to examine this tool in the future. 
Chapter 5

Shaping Executive Orders in the U.S. Courts of Appeals 
Like most presidents, President Obama has used executive orders (EO) to achieve a wide range of policy goals from labor relations $(\mathrm{EO} 13,495)$ to commerce and foreign affairs (EO 13,599). However, Obama's executive order use represents a downward trend in executive's use of this presidential tool. Passage of the Presidential Subdelegation Act of 1950 allowed bureaucratic agents to implement routine presidential responsibilities, eliminating the need for many executive orders (Mayer 2001,76). Executive orders are still used for routine matters (Warber 2006) but they are increasingly used to alter policy in more significant ways (Mayer 2001; Howell 2003; Fine \& Warber 2012). The use of this tool allows the president to operate outside the bounds of the traditional policy-making process, raising concerns about executive abuses of power. The burden to reign the growth of presidential power lies on the other branches of government and the people. However, research suggests that Congress (Moe \& Howell 1999), the courts (Howell 2003), and the media (Major 2014) have limited success in constraining the use of presidential executive orders.

While each institution has its weaknesses, the federal courts are the most viable and authoritative check on the exercise of executive power because life tenure is designed to insulate judges from political pressures. Using an original dataset of U.S. Courts of Appeals' written opinions involving executive orders from 1943 to 2013, this study examines the judiciary's role in checking presidential power and how interbranch relations influence the likelihood to uphold, constrain, and redefine executive orders. A new framework is developed that argues circuit panels do not have to uphold or strike down an executive order completely. Executive orders can be redefined with some parts being deemed executive overreach while the remainder of the order is upheld. By developing an expanded set of cases and examining the content of opinions to determine how executive orders are being applied to the case, this study identifies a previously 
neglected avenue for analyzing constraints on executive order use and shows this tool is more limited than previously believed.

This work contributes to scholarship on presidential powers, institutional relationships, and judicial politics. It shows executive orders are constrained, but in a more subtle and nuanced way than previously understood. The checks imposed by the court establish incremental limits on executive order use that create a legal framework presidents respond to and issue subsequent orders in. This research affirms the importance of the U.S. Courts of Appeals as a political actor, arguing they have the ability to overcome their institutional weaknesses and constrain presidential power. Finally, it shows litigants do not always fully win or lose. Judges can shape the law subtly in their opinions.

To examine the role of circuits in shaping the use of executive orders, this essay proceeds in four parts. First, the extant literature on executive orders is explored to identify the limited attention paid to the judiciary. Second, a theory is developed where the U.S. Courts of Appeals send subtle signals to the executive to redefine executive order use. Third, hypotheses and a model are developed using an original dataset of 371 cases to identify the mechanisms influencing judicial decision making. Finally, the results are examined and avenues for future research are explored.

\section{A Unilateral Tool}

The president has many tools to influence policy but a growing research program focuses on executive orders because they carry the full weight of law (Cooper 2014). They are increasingly used for more significant purposes (Mayer 2001) allowing the president to circumvent a hostile Congress (Krause \& Cohen 1997; Fine \& Warber 2012) or work in tandem 
with Congress to bolster legislation (Moe \& Howell 1999). Regardless of the purpose, the president faces minimal repercussions (Howell 2003; Major 2014).

When issuing an executive order, the president must anticipate responses from the public and other branches of government (Howell 2003), but evidence shows executive power is rarely checked by Congress (Moe \& Howell 1999), the federal judiciary (Howell 2003), or the media (Major 2014). The lack of formal checks allows the president to act with minimal fear of retribution, pushing scholars to focus on why and when the president uses executive orders (Gleiber \& Shull 1992; Krause \& Cohen 1997; Deering \& Maltzman 1999; Moe \& Howell 1999; Mayer 2001; Howell 2003; Warber 2006: Fine \& Warber 2012; Young 2012). Scholars rightfully focus on understanding how presidential-congressional relations effect executive order use. However, with very few exceptions, most neglect the role of the judiciary (see Howell 2003). The courts are viewed as a passive actor unlikely to check presidential power even though they are the most capable to do so because life tenure is meant to insulate judges from political and public pressures. This study focuses on how the U.S. Courts of Appeals constrain executive order use by sending subtle signals to the executive that shapes the limits of this power. The findings suggest circuit courts do limit the growth of this presidential tool by engaging in nuanced opinion writing, making contributions to the unilateral powers literature, presidentialexecutive relations, and judicial decision making.

\section{Strong Signals: Challenging the President}

Despite the lack of an explicit Constitutional power to issue executive orders, all presidents use them to "take Care that the Laws be faithfully executed" (Article II, section 3) (Dodd 2013). Legal scholars examine the constitutionality of individual executive orders and the courts treatment of them to determine their impact on constitutional law (Rosenberg 1981; 
Neighbors 1964). Individual case studies provide specificity but make it difficult to draw generalizations about how the courts handle executive orders as a class of cases.

Subsequent studies examined presidential-judicial relations by looking at direct challenges to any exercise of presidential power (Ducat \& Dudley 1989; Yates \& Whitford 1998). However, these studies produce mixed findings because they look at the district courts (Ducat \& Dudley 1989) and the Supreme Court (Yates \& Whitford 1998). In an attempt to overcome these limitations and provide an isolated analysis of executive orders, Howell (2003) identifies statutory and constitutional challenges to executive orders at all levels of the federal judiciary to determine when the courts directly challenge the president. Only when cases reach the Supreme Court is the judicial branch likely to oppose an executive order and check presidential power. ${ }^{10}$ Within this restricted sample opposition to the president is rare, with only fourteen cases going against the president at all levels of the federal judiciary between 1942 and 1998 (Howell 2003).

The limited impact of the federal courts is attributed to its institutional weakness. It cannot actively pursue cases and has no enforcement mechanisms, it must rely on its reputation (Baird 2001) and require the executive branch to implement rulings (Howell 2003; Cadeira 1986). When a ruling goes unenforced by the executive, it hurts the institutional legitimacy of the judicial branch. Deciding to overturn an executive order puts the courts in an uncomfortable position because it requires the president to enforce the limitation of executive power. The president can choose to ignore the ruling or issue a new order accomplishing the same policy goal, forcing the judicial process to start over. Both presidential responses call attention to the judiciary's weaknesses and harm its reputation.

\footnotetext{
${ }^{10}$ For case examples see Youngstown Sheet \& Tube Co. v. Sawyer (1952), Cole v. Young (1956), and Hampton v. Mow Sun Wong (1976)
} 
There is a substantial literature on the Supreme Court's interpretation of executive actions (Sheehan 1990; 1992; McGuire 1998; King \& Meernick 1999; Yates 1999; 2002; Curry, Pacelle \& Marshall 2008) and the president's attempt to influence those decisions (Segal 1990; Bailey, Kamoie \& Maltzman 2005; Black \& Owens 2011; Black \& Jones 2012), but the Supreme Court is unique because discretion over its docket allows the Court to avoid interbranch conflicts that can harm its reputation. The circuit courts do not have the same flexibility in controlling their docket, but their preference to maintain institutional legitimacy is no less (Carrubba 2009; Staton 2006). Viewing decisions through the lens of dichotomous outcomes, circuit courts regularly defer to exercises of presidential power and only constrain the most egregious abuses (Humphries \& Songer 1999). The incentive to defer to the president should be even stronger in executive order cases because it forces circuits to directly confront the president's use of an institutional tool. Indeed, circuits regularly uphold the president's executive order use (Howell 2003). Previous research suggests there should be limited evidence of judicial constraint on executive order cases because there is minimal incentive for circuits to challenge the president. This study shows there are subtle levels of constraint, allowing circuits to overcome even the greatest institutional weaknesses. Importantly, the results found here suggest the theory of subtle signals through nuanced opinion writing can be generalized to areas where circuits are less constrained by interbranch considerations.

While the lower courts rarely nullify an executive order, the bulk of adjudicatory activity involving executive orders occurs in the U.S. Courts of Appeals (Howell 2003). Only four of Howell's (2003) fifty cases went against the president at this level, suggesting circuits play only a marginal role in defining executive order use despite their prominent role in the American political system (Songer, Sheehan \& Haire 2000; Klein 2002; Hettinger, Lindquist \& Martinek 
2006). Very few cases reach the Supreme Court (Cross 2007) making the circuits the final arbiter in most issues (Davis \& Songer 1989; Klein 2002). The importance of circuits is bolstered by findings that suggest judges do not take Supreme Court preferences (Klein 2002), or the possibility of reversal (Bowie \& Songer 2009), into account when making decisions. The decisions and precedents set by circuits can stand for years until the Supreme Court grants certiorari, which rarely occurs especially if multiple circuits are in agreement with a legal rule (Bowie \& Songer 2009).

When the Supreme Court does decide an executive order case, circuits still have a significant role interpreting that ruling (Westerland et al. 2010) which can greatly affect how the law is applied in the particular circuit (Canon \& Johnson 1998; Lee 2003). A circuit's precedential authority is limited by the geographic territory the circuit covers (Klien 2002) but that does allow them to set vertical precedents which shape district court decisions in important ways (Carp 1972; Boyd 2015). This institutional design applies to most circuits but the DC Circuit is unique because it also has topical jurisdiction, giving it considerable authority over executive agency rule-making which has national implications (Banks 1998; Caruson \& Bitzer 2004). The growth of executive power and the circuits' continued deference to the president suggests circuits are evading their constitutional responsibility to check a presidential tool that in many ways circumvents the constitutional requirements of policy making (Krause \& Cohen 1997; Fine \& Warber 2012). If one takes a limited view of only direct constitutional and statutory challenges the results support this argument. However, when one moves beyond direct challenges to take a more complete view, the circuit courts do significantly contribute to defining executive power. 


\section{Subtle Signals: Shaping the Presidency Through Nuanced Decisions}

Executive orders are administrative tools to direct bureaucratic action toward achieving presidential policy goals (Cooper 2014). Examining only constitutional and statutory challenges neglects cases that deal with agency or private compliance and the administration of the executive branch, cases likely to be heard in the circuit courts but not reach the Supreme Court. Cases of administration and compliance provide circuits the best opportunity to define the limits of executive power. Agencies can interpret executive orders broadly in an attempt to more effectively implement presidential policies. They can prosecute private actors for noncompliance or private actors can challenge regulations implemented by agencies, forcing the courts to interpret the executive order. Judges are then faced with determining if an agency acted within the authority set forth by the executive order or redefine the limits of authority.

Circuits may act with restraint when deciding executive order cases, but that does not mean they are reviewing executive orders as all or nothing. Circuits can redefine the scope of an executive order by acknowledging the legitimate use of an order or chip away small parts of the order when it exceeds presidential authority. Moderate constraint shows deference to the president's general intent but allows circuits to check executive authority. The reinterpretation of the executive order serves as a signaling mechanism to the president. The president interprets judicial opinions to see how executive order use is defined by the judiciary and works within the newly delineated limits of power.

Subtle signals and moderate constraints have implications and set precedents important to defining the future exercise of executive power. Opinions do not require a direct challenge that nullifies an executive order. For instance, most presidents issue executive orders defining procedures and regulations agencies must follow to classify documents. These orders are of 
significant importance because actors submit Freedom of Information Act (FOIA) requests for documents agencies can withhold under the authority of the executive order. Circuits regularly allow agencies to withhold documents, but that ability has been limited through court rulings. In Summers v. Department of Justice (1998), the DC Circuit held that agencies have the authority to withhold documents, but the executive order does not give agencies unlimited discretion in determining what can be classified. The panel ruled agencies must explain the national security risk associated with releasing the information. The decision did not challenge the president directly, it recognized the legitimate use of executive power, but it defined how agencies were to implement the executive order. This ruling redefined the limits of the executive order use, altering what agencies classify and how future executive orders define national security risks. Cones v. Shalala (2000) provides another an illustrative example. Executive Order 12,839 required agencies to reduce their workforce, which the court held is within the president's power. As the chief officer of the executive branch the president has the authority to reorganize and reduce the number of bureaucrats to execute executive duties. However, when Secretary of Health \& Human Services employee Kenneth Cones believed he was denied a promotion because of his race, he challenged the authority EO 12,839 granted Secretary Donna Shalala. The DC Circuit held that this employment action was an abuse of the authority the executive order granted. In passing up Cones for promotion based on his race, Secretary Shalala abused the authority of the executive order. The DC Circuit held that hiring, firing, and promotions are legitimate exercises of executive authority, but said that they must be merit based and not discriminatory. By restraining the authority granted to Secretary Shalala, the court did not fundamentally alter presidential power. The DC Circuit did signal to the president he and 
executive agents were exceeding their authority, limiting the extent of the executive order and redefining executive power.

These cases illustrate the importance of moving beyond current methods of examining executive order cases and toward more rigorous coding of opinions. Without examining the panel's treatment of the executive order in these cases, orders are coded as upheld because they were not overturned. However, in both cases the DC Circuit signaled the president exceeded executive power and redefined the limits of executive order use. These cases provide anecdotal evidence but lack a theoretical basis for understanding when circuits will engage in nuanced opinion writing that subtly constrains executive power. A more complete understanding of executive-judicial relations is presented here by using an original dataset to account for the subtleties the U.S. Courts of Appeals employs to define executive order use.

\section{Understanding Subtle Signaling}

Political Considerations: To gain the most leverage in determining when circuits engage in nuanced decision making, variables examining the political makeup of judges hearing the case (Songer \& Davis 1990; Songer, Ginn \& Saver 2003), the relations within the panel (Sunstein et al 2006; Kastellec 2010), and the relationship to the president (Kuersten \& Songer 2003) provide the most interesting avenue for research. ${ }^{11}$ Federal judges are appointed for life to insulate them from political pressures, but circuits set policy and presidents pick judges they believe will vote in concordance with their preferences over time (Kuersten \& Songer 2003).

The judicial hierarchy is an important factor in circuit decision making (Kastellec 2011) but Howell (2003) shows relatively few executive order cases reach the Supreme Court, providing circuit judges additional freedom to act without fear of Supreme Court reversal (Bowie

\footnotetext{
${ }^{11}$ Circuit cases are randomly assigned to a panel that commonly consists of three judges. The composition of panels can be any mix of judges appointed by a Democrat or Republican president.
} 
\& Songer 2009). Acting as the final arbiter (Songer, Sheehan \& Haire 2000), circuit courts are free to decide according to their preferences with partisan politics likely to influence judicial decisions. The easiest measure of partisan influence is the presence of a president's appointee on the panel hearing the case. The effect of a single "counter-judge" on a panel has been shown to influence final decisions (Kastellec 2010). The presence of a single presidential appointee should have the same effect in swaying colleagues.

The partisan composition of the panel should also influence the outcome (Howell 2003; Sunstein et al. 2006). When the number of judges sharing the party of the president on a panel increases, there should be fewer instances of constraint for two reasons. First, party affiliation is used as a short cut for policy preferences. Individuals identify with a particular party because party policies tend to align with personal preferences. This effect is more acute when presidents nominate judges because they want to pick judges that will uphold party policies in the future. Therefore, more partisans on a panel should increase the probability of an order being upheld. Additionally, party division between Democrats and Republicans has become more polarized, driving party members apart and reducing the likelihood of supporting the opposition. The partisan divide should drive partisans to support their party leader. Two hypotheses test the effects of partisanship:

H1 - Appointee: The presence of a president's judicial appointee increases the probability that an executive order will be upheld.

H2 - Partisan: As the number of presidential partisans on a panel increases, the probability of that an executive order is upheld increases.

Partisan effects are important but judicial ideology also influences judicial decision making. The influence of ideology is especially acute at the circuit and Supreme Court levels 
because judges and justices move away from strict legal interpretations and toward an attitudinal model where decisions are based on individual preferences (Zorn \& Bowie 2010; Howell 2003).

The limited research devoted to the influence of judicial ideology on exercises of presidential power has mixed results. Some argue liberal district court judges are more likely to support the president (Ducat \& Dudley 1989,106) while others suggest liberal Supreme Court justices should constrain executive power (Yates \& Whitford 1982,542). One issue with these measures is that they treat the ideological composition of the panel hearing the case independent of the president. The ideological makeup can have an effect when examining cases that do not include another political actor. However, because a tool of the president is under question, the ideological distance from the president is more likely to matter than the panels general ideological composition. Therefore:

\section{H3 - Ideology: As a circuit panel becomes more ideologically aligned with the president's ideology, the probability of an executive order being upheld increases.}

Controls: Political variables are not the only factors likely to influence the decision to uphold or constrain executive power, details about the case also effect outcomes. The most commonly cited case variables are issue area, types of litigants involved, and in which circuit the case is heard (Ducat \& Dudley 1989; Songer \& Sheehan 1992; Yates \& Whitford 1998; Benesh 2002). Presidents issue executive orders covering a wide range of issues, both foreign and domestic. The president has an information advantage in foreign policy issues which allows greater latitude of action (Wildavsky 1975) and increased deference from the courts (King \& Meernik 1999; Adler 2004). This is especially true when the president is exercising his commander-in-chief power. When an executive order deals with defense or is issued during a war, the courts should be more likely to defer to the president. 
The president's commander-in-chief influence is unique because of the information advantage available. Domestic policies are more complex and require special attention. For example, courts might be less inclined to defer to the president on civil rights and liberty issues because unilateral action in these areas will arouse opposition from a wide range of societal groups.

Regardless of the issue under scrutiny, litigants have a large effect on the outcome (Galanter 1979). Litigants enjoy different success rates because they have varying resources, experience, and relationships with judges. Research shows the most common and successful litigants are governmental actors (Songer et al. 1999). The U.S. should be disproportionally involved as a litigant in executive order cases because agencies implement presidential policies. As those implementing an executive order, agencies are the most likely entity for groups to target when pursuing litigation. However, their repeat status gives them advantages over other groups. An agency's recurring appearance before the court provides the necessary experience to successfully defend the president's policies. Additionally, executive agents are trained to develop regulations that will successfully implement the president's executive order. During the development of regulations, agencies become experts in how an executive order interacts with current statutes, allowing them to be successful in arguing the legality of their actions.

The circuit hearing the case should also affect the outcome. The DC Circuit is of special interest because it has both geographic and topical jurisdiction (Banks 1998; Caruson \& Bitzer 2004). It hears cases dealing with administrative rule making, in this case the actions taken by agencies to implement an executive order. Rulings by the DC Circuit set constraints on all agencies making the DC Circuit the most authoritative circuit. The prominence of this court increases their institutional standing, proving greater freedom to constrain executive order use. 
Finally, judges are influenced by statutes and precedent (George \& Epstein 1992; Howell 2003; Cross 2007). Anticipating a judicial response, presidents can cite congressional statutes in the vesting clause of the executive order. Grounding an executive order in the law can appeal to a judge's legal mindset, increasing the possibility of an executive order being upheld.

\section{Data and Methods}

U.S. Courts of Appeals cases with a published decision from 1943-2013 are used to examine when the judiciary engages in nuanced opinion writing to define executive power. A WestLawNext search was conducted with the term "Exec Order." This allowed for the abbreviation of executive to be included but also searched for the full term "executive order." This search yielded 1,247 cases. Next, each case was searched for the term "order," making sure a specific presidential executive order was mentioned at least twice in the opinion. The term “order" was used because some opinions cite a specific executive order and then subsequently refer to it as the "order."

Temporal constraints matter because political parties change and the relevance of an executive order can fade. Choosing an appropriate cut point after an executive order is issued is challenging. If an executive order is not challenged within twenty years of issuance, cases involving that executive order are no longer included in this sample. Shorter periods have been used to account for the variability of public attention (Howell 2003), but orders can have an influence for an extended time. Twenty years is used in this study which accounts five presidential administrations. That is sufficient time for an executive order to be implemented, presidentially repealed by a new administration, or challenged. It also allows for greater variation in panels as new judges are appointed, allowing for a better test of partisan and ideological effects. The final sample meeting these criteria includes 371 cases. 
Choosing an executive order: Like most court cases, those involving executive orders are multidimensional. Sometimes they focus on a single order, but other times there are several executive orders cited in the opinion. When there are multiple orders, choosing one order over another can have a significant impact on the analysis. Choosing which executive order to assign to the case is a two-step process. First, the total number of citations for each order is counted and the order that is cited the most is assigned to the case. When there are multiple orders mentioned, the order mentioned most is used as the unit of analysis because it has the most influence on the outcome. Second, if multiple executive orders are cited an equal number of times, the most recently issued executive order is assigned to the case.

Dependent Variable: The dependent variable is an ordered categorical variable that measures the level of nuance in the opinion - no constraint, moderate constraint, or high constraint. The opinions developed by circuits contain important nuances commonly missed when examining the judiciaries role in shaping executive order use. Moving beyond coding cases as wins and losses for litigants is important because the executive order might not be the primary issue in the case. However, the executive order can be used to support the decision the panel reaches on the primary issue. This will provide circuit courts the ability to shape executive order use subtly as they interpret the limits of the order.

Determining the level of constraint requires a thorough analysis of case opinions. Typically, if an executive agency is involved and the agency wins (loses), the executive order is upheld (constrained). However, there are instances where an agency is unsuccessful but the executive order is upheld. For example, in Morris County Trust for Historic Preservation v. Pierce (1983), the Historical Society cited EO 11,593 that required the Department of Housing and Urban Development (HUD) to complete a thorough investigation of a building before 
demolishing it. The Third Circuit found that the agency did not follow these regulations, thus upholding the executive order while siding with the Historical Society over HUD.

Executive orders coded as upheld use clear language that cite the order as law, say the order supports the opinion, or require actors to follow the order. For instance, Dangerfield Island Protective Society v. Babbitt (1994) states, “...we conclude the Park Service has met the requirements of the executive orders..." Additionally, cases that are dismissed because of procedural thresholds such as non-exhaustion of administrative procedures (USAA Federal Savings Bank v. McLaughlin 1988), mootness (Todd v. Joint Apprenticeship Committee 1964), or lack of jurisdiction are coded as upheld and constitute de facto support for the president's use of an executive order (Howell 2003,151).

Moderate constraint, which occurs in several ways, takes place when circuits engage in nuanced opinion writing. First, when an opinion places limits on grants of authority, it is coded as constrained. In Association for Women in Science v. Califano (1976) the DC Circuit concluded that the regulations issued by the Secretary of Health, Education and Welfare establishing requirements for the assessment and dissemination of information when there is a conflict of interest went beyond the scope of the executive order. The DC Circuit determined this action exceeded the authority granted by the executive order but did not nullify the executive order in entirety. They limited the scope of authority the executive order granted. In Groves v. US (1976), the Fifth Circuit recognized the Secretary of Interior's ability to act but limited the executive order when the Secretary invoked the order's authority to create a new policy group. Second, a panel can place additional constraints by articulating administrative or procedural limits after acknowledging its legitimate purpose. In Gayer v. Schlesinger (1973) the DC Circuit held that EO 10,865 gave executive agents the authority to deny or revoke security clearances, 
but only according to the equitable procedures proscribed by the court. Finally, temporal constraints are coded as moderate constraint. In Burrell v. Martin (1955) litigants attempted to retroactively apply an executive order but the court would not allow the order to apply beyond its temporal limits.

High constraint uses clear language stating an order was in violation of a statute or the constitution. This does not require the order to be completely overturned. It is a way for the courts to signal to the president an executive order does not apply in all cases or that the president is encroaching on the limits of unilateral power. ${ }^{12}$ For instance, in Equal Employment Opportunity Commission v. American Telephone and Telegraph Company (1974) the Third Circuit said that “...the CWA [Communications Workers of America] can have no statutory right to intervene under the regulations issued under Executive Order 11246, since that order is not a statute of the United States." By arguing the executive order is not treated as a statute, it signaled to the president what the appropriate scope of this tool's authority is.

Finally, there is a coding challenge when executive orders are mentioned in the dissent but not the majority opinion. These cases are included even though they do not have precedential value because they still send a signal to the executive on how the courts are interpreting executive order use. For instance, in Sagebrush Rebellion Inc. v. Watt (1983) Judge Wallace of the Ninth Circuit wrote a dissent stating that Secretary Watt's “....authority is most clearly expressed in section of 5 of Executive Order No. 6166...” The majority's rejection of this position, and their constraint of Secretary Watt's authority, is a limit on the reach of executive order 6166 even if the majority is not directly addressing the issue.

\footnotetext{
${ }^{12}$ This includes four cases where the courts overturned an executive order. These are not measured independently because the low number of observations limits the available modeling techniques.
} 
Political Variables: Two sets of political variables are included - partisan and ideological. Data for judges are collected from judicial biographies available through the Federal Judicial Center. The first partisan measure captures the presence of a presidential appointee on the panel hearing the case. AppointedJudgePresent takes the value of 1 if a judge on the panel was appointed by the president who issued the executive order under question and 0 otherwise. The remaining partisan measures use the party of the appointing president as a proxy for judicial party. When a sitting judge shares the party of the president who issued the executive order under question, that is coded as a partisan match. PartisanPanel is a continuous measure ranging from 0 , no partisans, to 1 , a fully partisan panel. This is the simple measure of partisan relationships and captures both Democrat and Republican partisan panels. For additional nuance, DemPartisanPanel and GopPartisanPanel are continuous measures ranging from 0, no partisans, to 1, fully partisan, that capture the partisan effects of Democrat and Republican panels. Panels are determined Democrat if more than $33 \%$ of the panel was appointed by a Democratic president. Conversely, panels are determined Republican if more than $33 \%$ of the panel was appointed by a Republican president.

Finally, to gain leverage on panel dynamics, finer measures are used to determine if an opposition judge can influence the outcome. DemMixedPartisanPanel, DemFullPartisanPanel, GopMixedPartisanPanel, and GopFullPartisanPanel capture both the panel composition and its relation to the president. ${ }^{13}$ For instance, mixed Republican panels oversee cases that involve a Republican president's executive order and consist of more than 33\% Republicans, but not 100\%. Full Republican panels are composed entirely of Republican judges hearing a

\footnotetext{
${ }^{13}$ When including nominal measures to isolate party and panel effects, opposition panels are the omitted category. Opposition panels have at least two judges who are of the opposite party from the president who issued the executive order under question.
} 
Republican's executive order. Democratic and Republican panels are determined the same as above and mixed panels contain at least one judge of the opposition party and full panels consist of $100 \%$ partisans. $^{14}$

Ideology is difficult to measure in the best of circumstances and judicial ideology raises additional challenges (Cross 2007). A common measure of a judge's ideology assigns Poole \& Rosenthal's $(1991 ; 1997)$ NOMINATE Common Space score of the appointing president to the judicial appointee. ${ }^{15}$ This measure is used to calculate ideological distance because it best approximates the president's ideology which is the driving force behind judicial decisions (Songer \& Ginn 2002). Most measures of ideological distance use the absolute distance between the president's ideology and the mean ideology of the panel. However, the absolute distance does not account for directionality, suggesting a panel with a mean ideology of -0.75 and 0.25 are of equal value when a liberal president has an ideological value of -0.25 . Empirically both produce an absolute value of equal value, 0.50 . However, they are substantively different because in one instance a liberal panel is hearing a liberal president's executive order and in the other a conservative panel is hearing a liberal president's executive order. Therefore, to calculate

IdeoDistance and account for directionality the following formula is used:

$$
L P=M-L P \text { or } C P=C P-M
$$

Where $L P$ is equal to the president's ideology score when the score is below zero, indicating a liberal ideology, and $C P$ is equal to president's ideology score when the score is above zero, indicating a conservative ideology. $M$ is equal to the mean ideology of the panel. This produces a continuous measure that ranges from -2 to 2 where negative values indicate $L P$

\footnotetext{
${ }^{14}$ The total party composition best captures the dynamics occurring on a panel (see Hettinger, Lindquist \& Martinek 2006; Cross 2007). However, some argue the median panel member is important in swaying panel decisions (Holcombe 1980). Additional models controlling for median appointees and partisans do not show any effects.

${ }^{15}$ For an alternative measure see Giles, Hettinger, \& Peppers (2001) and Boyd (2010).
} 
$>M$ and $C P<M$. Therefore, when the measure produces negative values, a liberal or conservative president would be dealing with a more liberal or conservative panel, respectively. ${ }^{16}$

The final political variable, SittingPresEO, measures the executive order in a case was issued while the issuing president is still in office, where yes is coded as 1 and no as 0 .

Control Variables: USAlitigant is dichotomous and measures if the USA is involved in the case as either an appellant or an appellee. This includes agencies and individuals as the head of an agency, where 1 is USA involvement and 0 is other. DCcircuit is a dichotomous variable that measures if a case was decided in the DC Circuit with 1 being yes and 0 being no. Punctuating events like major decisions by the Supreme Court shape the decisions of the lower courts. Youngstown Sheet \& Tube Co. v. Sawyer (1952) was a landmark case that significantly constrained the use of executive orders. Youngstown is dichotomous and codes cases decided form 1952-1973 as 1 and all others as 0. The cutoff date of 1973 is used because United States v. Nixon was decided in 1974. While this case does not deal with executive orders it was a turning point in presidential power where the Supreme Court tried to limit the growth of the imperial presidency. US v. Nixon has a value of 1 for cases from 1974-2013 and 0 otherwise.

Following Howell's (2003) test of the legal model of judicial decision making, StatutoryGrant is included to capture executive orders that contain a statutory grant of authority in the vesting clause with 1 coded as yes and 0 no.

The Agendas Project assigns policy areas to executive orders which are applied.

CivilRights is coded as a 1 if the Agendas Project categorizes an executive order as Civil Rights, Minority Issues, and Civil Liberties and 0 otherwise.

\footnotetext{
${ }^{16}-2$ and 2 represent ideological extremes with observations ranging from -.193 to 1.536 .
} 
The final controls consider the president's role as commander-in-chief. Defense is coded as a 1 if the Agendas Project categorizes an executive order as a defense order and 0 otherwise. War has a value of 1 if the United States is involved in a war when the executive order was issued according to the Correlates of War Project and 0 otherwise (Singer \& Small 1966). ${ }^{17}$

Method: Ordinary least squares regression is not the appropriate modeling technique because the dependent variable only takes the form of three values. Therefore, ordered probit is appropriate because the dependent variable is categorical and captures movement from no to high constraint with indeterminate levels of increasing value.

\section{Results and Analysis}

The results align with other studies that suggest the circuit courts generally defer to the president (see Figure 5.1). Deference occurs in 279 , or $75.2 \%$, of the cases. Additionally, there are very few cases, 16 or $4.3 \%$, in which circuits are placing a high constraint on the president's executive order use by invoking either a statutory or constitutional conflict. This leaves $20.5 \%$ of variance that is unexplained. These 76 opinions contain important nuance that allows circuits to subtly signal and constrain executive power.

Figure 5.2 shows the evolution of the U.S. Courts of Appeals treatment of executive orders over time. These are important data because the cases involving executive orders have decreased, with fewer cases annually, but also because incidences of constraint have decreased as well. This decrease in activity suggests that circuits are successful in shaping executive order use and presidents are responding to these subtle signals. This general trend is conjecture at this point and future research needs to thoroughly investigate executive responsiveness to these more

\footnotetext{
${ }^{17}$ The Correlates of War Project is continually updated and can be found at correlatesofwar.org.
} 
nuanced decisions. That is beyond the scope of this article, and the interest here is in identifying when the circuit courts engage in subtle signaling.

Figure 5.1: Types of Executive Order Constraint in the U.S. Courts of Appeals, 1943-2013

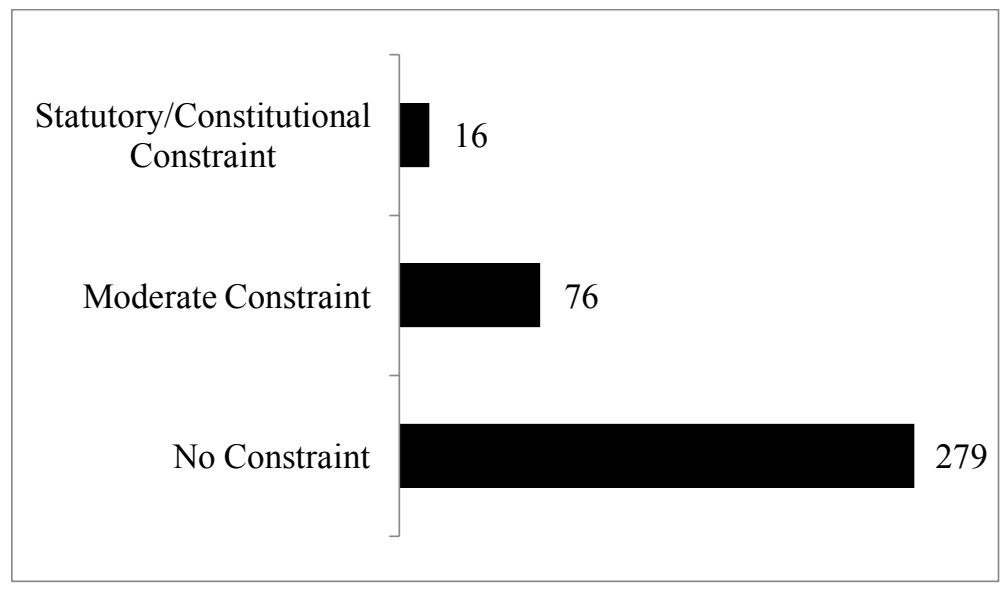

Figure 5.2: Types of Executive Order Constraint in the U.S. Courts of Appeals Over Time, 1943-2013

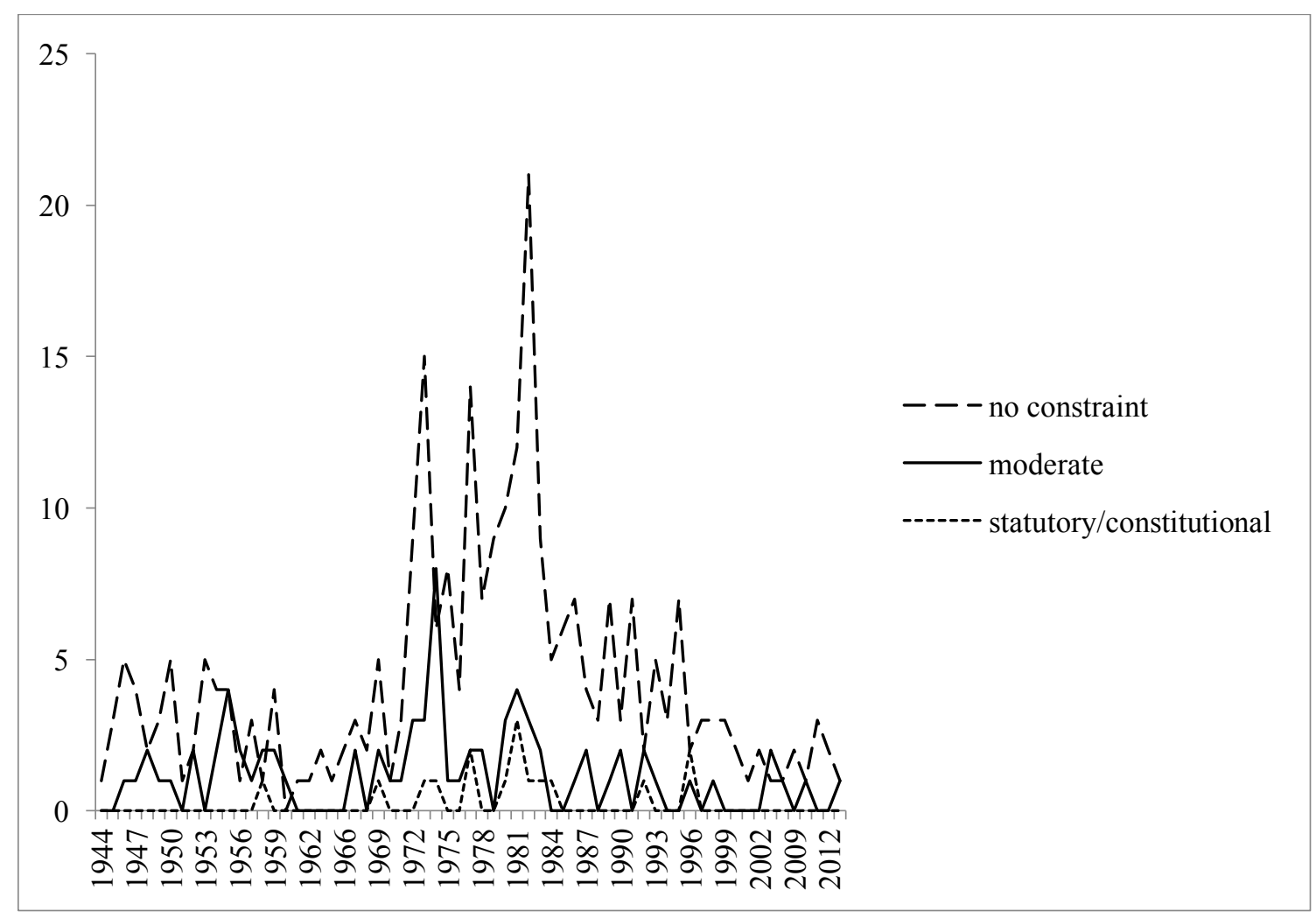


The raw data suggest more rigorous analysis is necessary to explain the variance occurring in opinion writing. Hypothesis testing yields mixed results (see Table 5.1). The simple partisan model shows both partisanship and ideology influence the treatment of executive orders. The negative coefficient for PartisanPanel is significant at the $\mathrm{p}<.05$ level, suggesting as more partisans sit on a panel there is a greater likelihood to uphold the executive order. IdeoDistance is also significant at the $\mathrm{p}<.05$ level but the coefficient has the opposite sign. This suggests as panels move away from the president's ideology, there is a greater likelihood to uphold an executive order. The preliminary analysis produces mixed results for the hypotheses.

The partisan and party model shows parties are acting differently, which aligns with previous research (Sunstein et al. 2006). While Democratic panels produce null results, Republican panels have the expected effect and the relationship is significant at $\mathrm{p}<.05$ level. The negative coefficient indicates greater levels of deference to the president as the number of judicial partisans increases. This finding lends support to $\boldsymbol{H} \mathbf{2}-\boldsymbol{P a r t i s a n}$ but this general partisan and party effect could also be influenced by panel effects (Kastellec 2011).

The final partisan, party, and panel effects model provides the greatest support for the hypotheses. Figure 5.3 shows the coefficient plots for the key variables used to test $\boldsymbol{H 1}-\boldsymbol{H}$. Both Republican panels and ideological distance are negative and do not have confidence intervals crossing the zero threshold, indicating significance at the $\mathrm{p}<.05$ level. The presence of an appointee on the panel does cross the zero line, producing null results and $\boldsymbol{H 1}$ - Appointee is rejected suggesting that judges do not feel an obligation to support their appointing president when determining executive order outcomes. Partisan and panel results, while mixed, indicate judges are influenced by party dynamics. $\boldsymbol{H} \mathbf{2}$ - Partisan is partially supported with Republican panels aligning with expectations and Democratic panels producing null results. 
Table 5.1: Upholding Executive Orders in the U.S. Courts of Appeals, 1943-2013

\begin{tabular}{|c|c|c|c|}
\hline 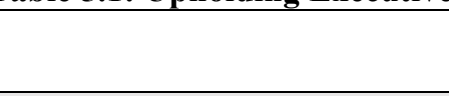 & Simple Partisan Model & $\begin{array}{c}\text { Partisan and Party } \\
\text { Effects }\end{array}$ & $\begin{array}{c}\text { Partisan, Party, and } \\
\text { Panel Effects }\end{array}$ \\
\hline \multicolumn{4}{|l|}{ Partisan } \\
\hline AppointedJudgePresent & $\begin{array}{l}.003 \\
(.163)\end{array}$ & $\begin{array}{l}-0.058 \\
(.161)\end{array}$ & $\begin{array}{l}-0.075 \\
(.162)\end{array}$ \\
\hline PartisanPanel & $\begin{array}{c}-1.007 * * \\
(.410)\end{array}$ & - & - \\
\hline DemPartisanPanel & - & $\begin{array}{l}-0.162 \\
(.307)\end{array}$ & - \\
\hline GopPartisanPanel & - & $\begin{array}{c}-0.957 * * \\
(.334)\end{array}$ & - \\
\hline DemMixedPartisanPanel & - & - & $\begin{array}{l}.031 \\
(.243)\end{array}$ \\
\hline DemFullPartisanPanel & - & - & $\begin{array}{l}-0.241 \\
(.329)\end{array}$ \\
\hline GopMixedPartisanPanel & - & - & $\begin{array}{c}-0.595 * * \\
(.255)\end{array}$ \\
\hline GopFullPartisanPanel & - & - & $\begin{array}{c}-0.920 * * \\
(.402)\end{array}$ \\
\hline SittingPresEO & $\begin{array}{l}-0.119 \\
(.170)\end{array}$ & $\begin{array}{l}-0.030 \\
(.173)\end{array}$ & $\begin{array}{r}-0.025 \\
(.174)\end{array}$ \\
\hline \multicolumn{4}{|l|}{ Ideological } \\
\hline IdeoDistance & $\begin{array}{c}-0.918 * * \\
(.379)\end{array}$ & $\begin{array}{c}-0.733 * * \\
(.357)\end{array}$ & $\begin{array}{c}-0.726 * * \\
(.362)\end{array}$ \\
\hline \multicolumn{4}{|l|}{ Case } \\
\hline USAinvolvment & $\begin{array}{l}-0.219 \\
(.176)\end{array}$ & $\begin{array}{l}-0.241 \\
(.177)\end{array}$ & $\begin{array}{l}-0.224 \\
(.178)\end{array}$ \\
\hline DCcircuit & $\begin{array}{l}.004 \\
(.159)\end{array}$ & $\begin{array}{l}-0.025 \\
(.160)\end{array}$ & $\begin{array}{l}-0.020 \\
(.160)\end{array}$ \\
\hline Youngstown & $\begin{array}{l}.093 \\
(.307)\end{array}$ & $\begin{array}{l}.403 \\
(.319)\end{array}$ & $\begin{array}{l}.332 \\
(.330)\end{array}$ \\
\hline US v. Nixon & $\begin{array}{l}-0.006 \\
(.316)\end{array}$ & $\begin{array}{c}.426 \\
(.347)\end{array}$ & $\begin{array}{c}.353 \\
(.358)\end{array}$ \\
\hline StatutoryGrant & $\begin{array}{l}-0.148 \\
(.196)\end{array}$ & $\begin{array}{l}-0.185 \\
(.198)\end{array}$ & $\begin{array}{l}-0.171 \\
(.199)\end{array}$ \\
\hline CivilRights & $\begin{array}{l}-0.233 \\
(.216)\end{array}$ & $\begin{array}{c}-0.431 * \\
(.232)\end{array}$ & $\begin{array}{c}-0.444 * \\
(.234)\end{array}$ \\
\hline Defense & $\begin{array}{l}-0.189 \\
(.219)\end{array}$ & $\begin{array}{l}-0.223 \\
(.220)\end{array}$ & $\begin{array}{l}-0.212 \\
(.221)\end{array}$ \\
\hline War & $\begin{array}{l}-0.089 \\
(.153)\end{array}$ & $\begin{array}{l}-0.022 \\
(.152)\end{array}$ & $\begin{array}{r}-0.025 \\
(.153)\end{array}$ \\
\hline $\mathbf{K}_{1}$ & $\begin{array}{r}-0.713 \\
(.618)\end{array}$ & $\begin{array}{l}-0.003 \\
(.553)\end{array}$ & $\begin{array}{c}-0.029 \\
(.559)\end{array}$ \\
\hline $\mathbf{K}_{2}$ & $\begin{array}{c}.348 \\
(.620)\end{array}$ & $\begin{array}{l}1.067 \\
(.560)\end{array}$ & $\begin{array}{l}1.044 \\
(.565)\end{array}$ \\
\hline$(N)$ & 371 & 371 & 371 \\
\hline
\end{tabular}


Republican panels are more likely to uphold a Republican president's executive order. When accounting for panel dynamics, this effect is strongest among full partisan panels. The coefficient for GopMixedPartisanPanel is in the expected direction and significant at $\mathrm{p}<.05$ level. The effect is stronger for GopFullPartisanPanel which also has a negative coefficient and is significant at $\mathrm{p}<.05$ level. The nature of ordered probit regression does not allow for the direct interpretation of the magnitude of coefficients but does allow for the calculation of predicted probabilities. $^{18}$

Figure 5.3: Hypothesis Testing: When Constraint Occurs in the U.S. Courts of Appeals, 1943-2013

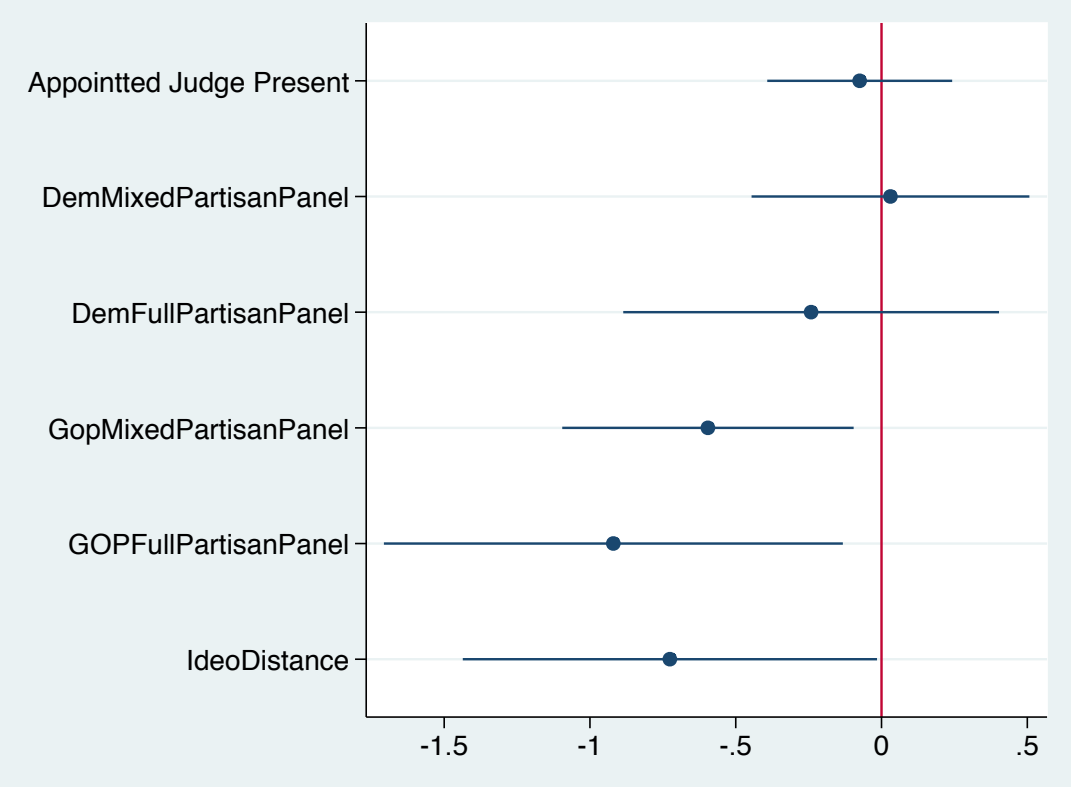

Figure 3 displays the coefficients and 95\% confidence intervals for key variables from the full Partisan, Party, and Panel Effects model

Mixed Republican panels deciding on a Republican president's executive order have an $85 \%$ probability of deferring to the president's exercise of power (see Figure 5.4). Republican panels still engage in nuanced opinion writing; however, the probability of moderate constraint

\footnotetext{
${ }^{18}$ Predicted probabilities are calculated by varying the measure of interest, holding ideological distance at its mean and all other variables at their modal value.
} 
drops 72 percentage points, down to $13 \%$. There is a smaller probability, only $2 \%$, that mixed Republican panels will constrain an executive order because of statutory or constitutional reasons. Full Republican panels are even more deferential to Republican presidents. They defer to the exercise of an executive order $91 \%$ of the time, and engage in nuanced opinion writing with moderate constraint $8 \%$, and statutory or constitutional constraint $1 \%$ of the time, respectively.

While these results strongly support $\boldsymbol{H} 2$, Democratic panels' treatment of executive orders do not reach statistical significance. The null results must be interpreted with caution but it suggests three reasons why Democrats are acting differently than Republicans. First, it might be that presidents are issuing different types of executive orders that produces differences in the results. Not all executive orders are created equally and some are more intrusive on the policy process. Future research, needs to include an analysis on the types of executive orders under review. Second, it might be a product of judicial philosophy. Democrats might see their duty as judges to remain insulated from political affiliation whereas Republicans feel less constrained by the trappings of the judiciary. Instead they see their role as policy makers which are regularly influenced by partisan forces. The differences in outcomes can speak to each party's view on partisanship. The Republican party tends to be more homogenous, promoting a shared sense of identity. Conversely, the Democratic party is more heterogeneous, supporting a range of social and economic policies, making it more difficult to use party as an indicator of compatibility. Because party identification can be unreliable as a cue, ideology can provide a more acute measure of preference alignment. 


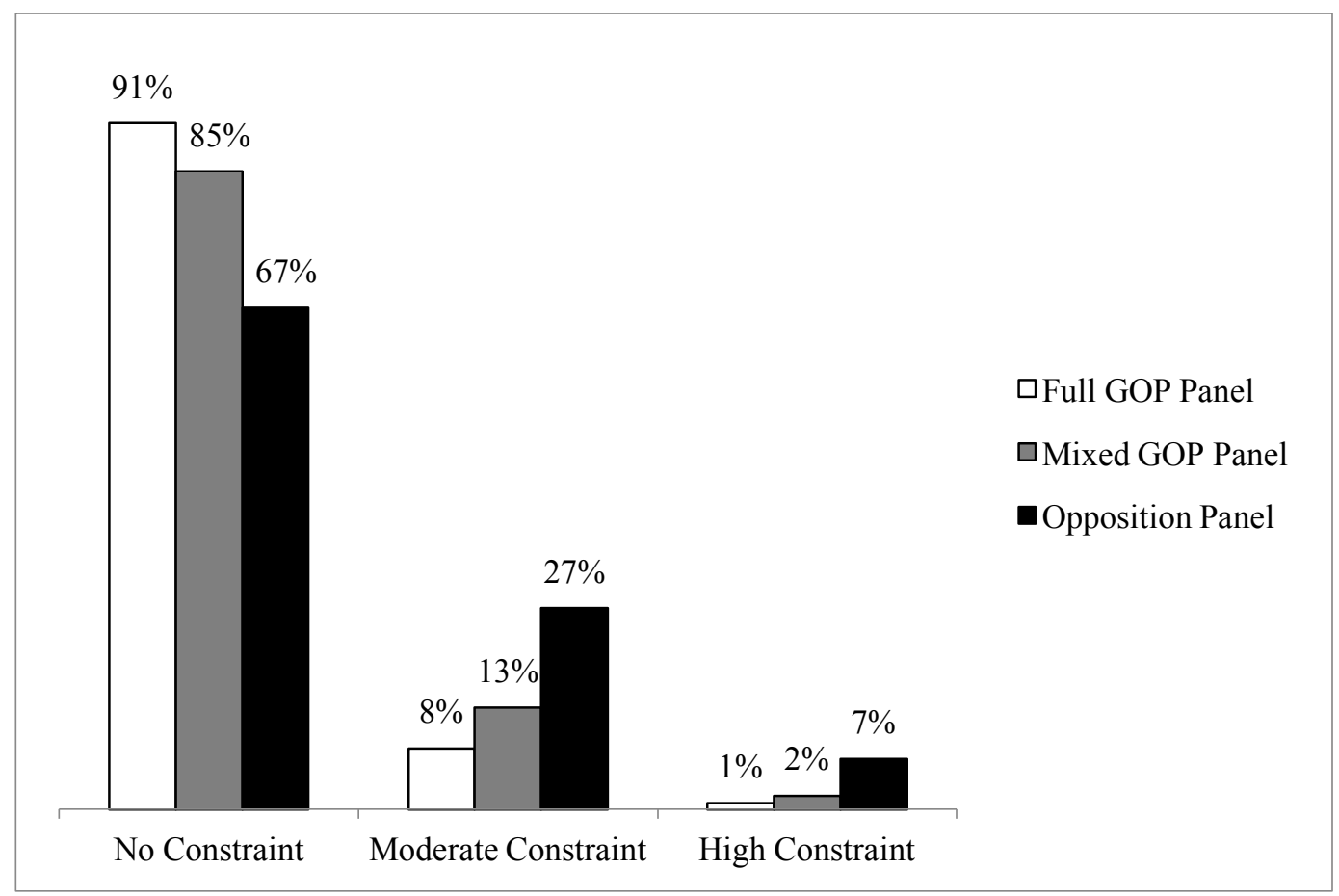

Predicted probabilites for Republican panels addressing a Republican president's execuitve order. Probabilities are calculated by holding ideology at the mean and all other values at their modal value.

Beyond party and panel effects, ideological distance does influence judicial decisions. The effect is in the opposite direction and significant at $\mathrm{p}<.05$ level, calling for a rejection of H3 - Ideology. The results indicate as the distance grows for $L P>M$ or $C P<M$, there is a greater probability of constraining executive action (see Figure 5.5). ${ }^{19}$ This suggests when a liberal president has an executive order under review by a group of extreme liberal ideologues, the probability of constraint is greater than if the panel were composed of conservative ideologies. While this is opposite of the anticipated effects, it is not unreasonable and aligns with explanations proposed during the discussion of partisan effects. While ideology and partisan affiliation differ, Democrats serve as a cue for liberal values and Republicans for conservative

\footnotetext{
${ }^{19}$ Predicted probabilities for ideology are calculated by controlling holding all variables at their modal value.
} 
values. Aware of this, judges might be hesitant to constrain ideological opponents for fear of being labeled partisan actors. While we see this is clearly the case for Republican panels, Democrats remain insulated from political pressures. Because judges treat executive orders as a body of law that will have lasting effects beyond the current ruling, judges might see greater opportunity to constrain presidents that are ideologically aligned. Constraining a president that shares the values of the panel insulates the circuit from external criticism, but shapes the framework of executive order use.

Figure 5.5: Predicted Probabilities of Constraint: Ideological Distance, 1943-2013

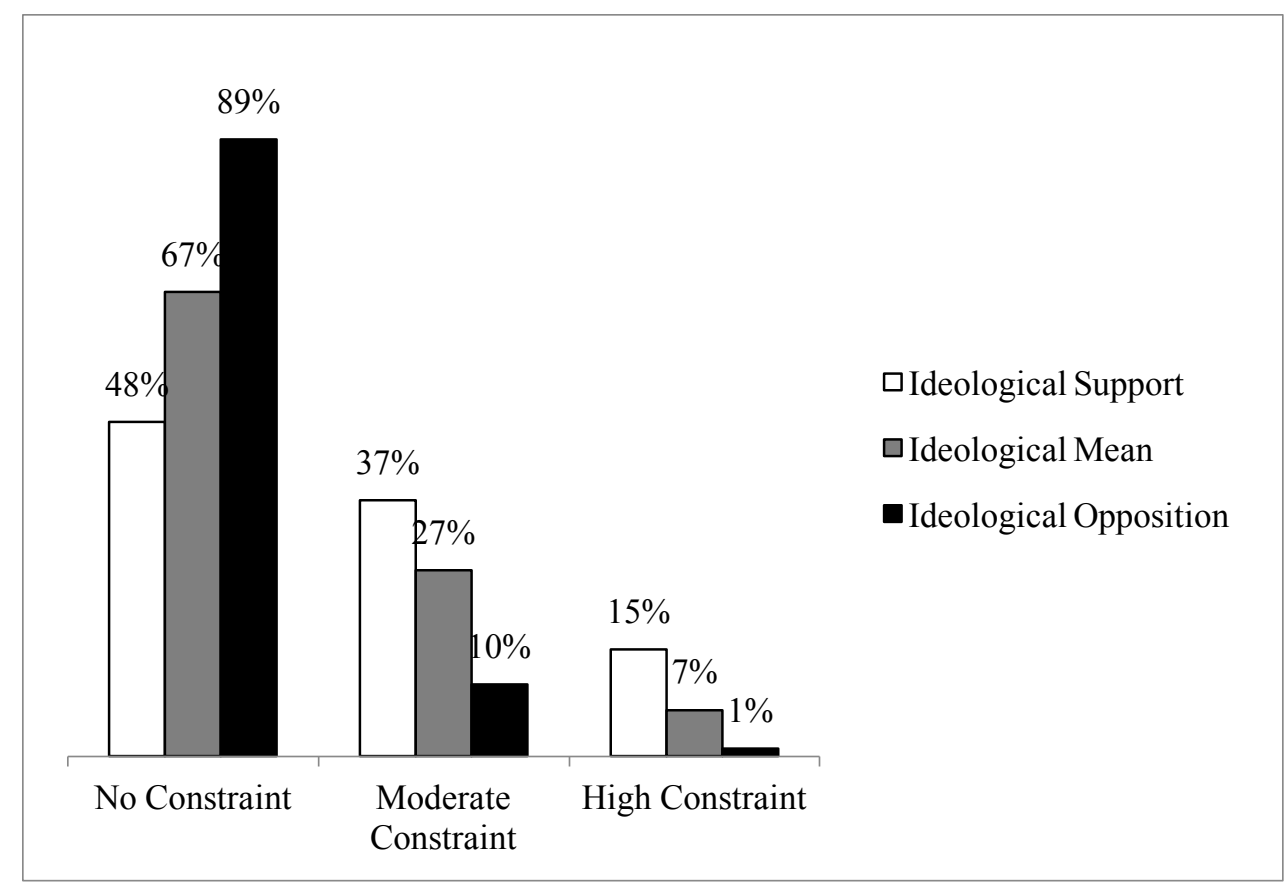

Predicted probabilites for are calculated by varying ideology all holding all other values at their mode.

Of the remaining control variables, only the civil rights issues variable is significant at $p$ $<.10$ level but in the opposite direction. The negative coefficient indicates panels are more likely to defer to presidential action in this area. There are two possible explanations for this alternative finding. First, presidents might be cautious when issuing executive orders in this issue area. 
Knowing the courts are likely to scrutinize presidential attempts to unilaterally influence civil rights issues, presidents might undertake additional steps to ensure orders fall within the limits of the law. Second, it might have to do with the coding scheme established by the Agendas Project. While this is the best coding available, it is difficult to place orders in unique categories (Mayer 2001; Warber 2006), and our understanding of categories might change over time. The remaining controls produced null results but one requires attention. StatutoryGrant was used to measure the influence of the legal model of decision making on outcomes. The null results signal that, at least in cases involving executive orders, the strength of legal arguments fade and political considerations take precedent.

\section{Conclusion}

The findings presented here make several important contributions. First, the investigation of circuit opinions provides important contributions to understanding presidential powers. Executive order use is thought to be a strong tool of the president that rarely faces challenges from the other branches (Moe \& Howell 1999; Howell 2003). This research identifies a previously underdeveloped area of executive constraint by examining an expanded case set of U.S. Courts of Appeals opinions. While the president does receive a great deal of deference from the courts, it is not unlimited and circuits place constraints on the scope of executive orders by crafting nuanced opinions that subtly constrain executive orders over time. These subtle signals force us to rethink the role of the courts. It allows the lower courts to develop a legal framework that has implications on the way presidents craft executive orders. The moderate constraints placed on this tool signal to the executive that the use of this tool is acceptable but must remain in the confines of the courts' understanding of presidential power. The general decrease of 
executive order challenges suggests the president is responsive to these signals and works within the bounds of judicially imposed constraints.

Second, this research provides more than individual accounts of judicial decision making and presidential power; it adds to our understanding of the relationship between the U.S. Courts of Appeals and the president. Partisanship matters when panels are making decisions on the exercise of presidential power. This is especially true for Republican panels which are more likely to uphold an executive order issued by a Republican president. Beyond party influence, panel dynamics also influence judicial decision making. Panels comprised of all Republicans act in greater concert with their Republican presidents and exhibit a high probability of deferring to the exercise of presidential power. The null results for Democratic panels suggest they are insulated from partisan pressures. These findings are important because they show that not all federal judges are insulated from political pressures once they take their seat on the bench. The relationship between judges and the president has an influence on outcomes. The differences between mixed and fully partisan panels also supports arguments that panel composition influences outcomes. The presence of a judge from the opposition party can have an influence on the final decision.

Finally, results presented here justify the extensive analysis of opinions necessary to identify the subtleties in circuit court decisions. Circuits are not locked into all-or-nothing decision making and can engage in more nuanced opinion writing behavior previously overlooked. While this study focuses on a small sample of circuit court cases, cases involving executive orders represent an area where circuits are least likely to engage in this type of nuanced opinion writing. This opens new avenues for research and requires new explanations of judicial decision making. Moving away from all-or-nothing decisions provides judges additional 
options which needs to be incorporated into theories attempting to explain how judges reach their decisions. As political actors who affect the content and scope of the law, circuit court judges have found a way to strategically shape the law while avoiding heated conflicts that might erupt from contentious all or nothing decisions. Trying to achieve policy goals in a single decision is difficult, especially when deciding on a collegial panel. The security of life tenure allows federal judges to shape the law over time. While it may be incremental change, a judicial career that slowly shapes the law can have significant policy implications. Future research can leverage nuanced opinion writing in several ways. It can expand the sample of cases to see how and when circuits are subtly shaping the law in other issue areas. Additionally, it can trace the role individual judges play in shaping the law over time to gain insights to judicial behavior and the role of presidential appointees. 
Chapter 6

Conclusion 


\begin{abstract}
We are not just going to be waiting for legislation in order to make sure that we're providing Americans the kind of help that they need. I've got a pen, and I've got a phone. And I can use that pen to sign executive orders and take executive actions and administrative actions that move the ball forward in helping to make sure our kids are getting the best education possible, making sure that our businesses are getting the kind of support and help they need to grow and advance, to make sure that people are getting the skills that they need to get those jobs that our businesses are creating...

-President Barack Obama 2014
\end{abstract}

This is the same quote by President Obama used in the opening chapter. It is repeated here because it is important to revisit Obama's statement with a better understanding of how executive orders are used, when they are used, and what the limitations to their use the judiciary imposes. The pen of the president is a strong tool and much can be accomplished with it. Can presidents use executive orders to set education mandates? Can an executive order fund businesses and create incentives for advancement? Can an executive order directly create jobs? Critics of executive orders would lead the reader to believe yes, executive orders are an expansive tool of the president that under-cuts Congress and allows unilateral presidential action that has boundless possibilities. After reading the research conducted here, it should be apparent that this is not the case and it would be difficult to answer any of those questions with a definitive yes.

As much as presidents might want the ability to substantially shift policy unilaterally through the use of executive orders, they do not have this ability. Presidents do not have that much power, nor should they. It takes some policies four or more years before results become apparent. The fickleness of executive orders would mean every time an opposition administration came into office, policy would radically change and institutional learning would have to occur all over again. What presidents can do with executive orders is alter policy and draw the status quo closer to presidential preferences, not radically change policy. However, how that is done has been a mystery until now. 
This research shines light on a dark area by developing a new framework to examine executive orders and analyzing their interaction with the bureaucracy. Although nearly every definition of executive orders includes a component that addresses the interaction between the president and the bureaucracy, the studies based on that definition neglect what that interaction is. It is assumed executive orders present a clear, explicit policy command and executive agencies carry out that command. There are major weaknesses in this assumption if for no other reason than no part of the political or policy process is devoid of nuance. No action by the president, Congress, or the courts is so straight forward.

Delving into the presidential-bureaucratic relationship illuminates the nuances of executive order use. The president can use this single tool to do more than command agencies to implement specific presidential policies. While this is the most common conception for how executive orders are used, and the most common type of order to be issued, this research shows the president can direct bureaucratic agencies in multiple ways with executive orders.

Figure 6.1: Types of Executive Orders, 1953-2012

DISCRETION

\begin{tabular}{l|c|c} 
& Low $(0-2)$ & High (3+) \\
\cline { 2 - 3 } & Routine & Hortatory \\
\hline Low $(0-2)$ & Coercive & Catalytic
\end{tabular}

Numbers in () denote the number of affirmative responses to coding questions

Using a set of sixteen questions, each executive order is read and systematically coded into one of four mutually exclusive groups depending on the amount of authority and discretion the president grants executive agents (see Figure 6.1). Each type of executive order is used for a 
different purpose, expanding our understanding of this presidential tool. While the types of executive orders are more fully developed in Chapter 2, routine, coercive, hortatory, and catalytic orders are briefly reviewed here. Coercive orders align with the most common conception of an executive order's role in the policy process. They provide limited discretion but a high level of authority to act. The coercive order operates as a clear, direct command from the president to bureaucratic agents. This type of order rarely has the significant policy implications most studies of executive orders suggest. Instead, they are used to fill in specific gaps in policy. Contrary to coercive orders, catalytic orders are used to achieve significant policy shifts. This type of order provides executive agents high levels of authority and discretion. It is a way for the president to focus agency attention on a specific issue area without articulating a mandatory outcome. However, because bureaucratic actors are agents of the president, they will develop and implement policies that align with presidential preferences. By shifting the policy process to the bureaucracy, it allows the president to use less precise language that Congress can cite as an attempt to circumvent the traditional policy process. Catalytic orders do tend to be more significant and are an attempt of the president to circumvent Congress and unilaterally move policy by using the bureaucracy.

Coercive and Catalytic orders are the categories with the greatest immediate impact on policy, but hortatory orders are also used by the president to influence policy. They are most commonly used to create an exploratory committee to investigate a policy area and provide information to the president. Hortatory orders are comprised of high levels of discretion but low levels of authority where executive agents have the freedom to investigate, define, and prioritize policy in an issue area but do not have the ability to implement policy. These orders do play a critical role in the policy process because they provide the president the information necessary to 
make informed policy decisions. Routine orders are the final type of order and do not have a significant effect on policy. They contain low grants on both dimensions and are used for routine bureaucratic tasks like closing federal offices for a holiday or symbolic purposes like medal design.

The method of coding used here and the disaggregation of executive orders into four mutually exclusive categories are major theoretical contributions for several reasons. First, the method of coding allows for the independent analysis of executive orders. Previous studies judge the significance of an executive order based on the response from outside actors - Congress, the courts, the media. This ties the measurement and analysis of executive orders to those actors. This contradicts a key assumption of the tool, that it is a unilateral power that allows the president to act first and without constraint from outside actors. If independence serves as the foundation for executive order theories, the tool should be measured and analyzed independent of other actors. This research accomplishes that by analyzing the text of executive orders and developing the mechanisms used to provide an understanding of how presidents use this tool.

The creation of four mutually exclusive categories is also an improvement over the common dichotomous measurements. Dichotomous measurements are flawed because they isolate a single category of interest and group the remaining executive orders into a single group - significate or not, policy related or not. This limits the explanatory value of executive order research because only a narrow selection of executive orders can be determined empirically significant under a limited set of conditions. For instance, significant executive orders can only attain statistical significance under unified or divided government, but not both. The most well developed theories of executive order use argue presidents act strategically and issue more significant executive orders under divided government to circumvent a hostile Congress. While 
this makes intuitive sense, it suggests the president is only acting strategically under divided government. The argument developed here is that there are different types of executive orders, used for different purposes, that have greater or lesser utility depending on the institutional context the president is faced with. The additional nuances distinguished and judged independently from other actors, moves the field forward in an attempt to overcome these shortcomings and provide a better understanding of executive order use.

Drawing from theories common to executive order research, hypotheses are developed to determine when the president is likely to issue different types of executive orders. Two arguments dominate the literature. The most common suggests the president issues executive orders to circumvent Congress under divided government when he is unable to achieve his policy preferences through traditional means. The second argument suggests the president issues executive orders to work with Congress under unified government to bolster legislation. Limiting the examination of executive orders to dichotomous categories did not allow for theoretical arguments that unify competing theories. In an attempt to do so, this research argues catalytic orders are issued under divided government to shift the policy process to the bureaucracy and circumvent Congress. Under unified government, the president should issue more coercive executive orders to fill in the gaps of legislation because there is support from the president's party to act unilaterally.

The statistical analysis fails to unify the competing claims, but does bolster arguments that the president issues executive orders to circumvent Congress during divided government. The president does issue more catalytic executive orders when there is less support in Congress. While the tests for coercive orders produce null results, the findings still provide an important contribution. Until this research, the mechanism for circumventing Congress was unknown. It 
was assumed a direct command from the president was given to the bureaucracy to carry out a specific policy that ran contrary to Congressional wishes. That is not that case. Executive orders used to circumvent Congress are broad policy statements that allow agents of the president to develop and implement policies they believe align with the principle's agenda. This finding raises new questions for future research about bureaucratic response and the types of policies developed.

The final component of this research addresses a large gap in the executive order literature and extends our understanding of constraints and limitations the executive faces. Once an executive order is issued, few researchers find any significant check on the exercise of this presidential power. The findings here suggest the U.S. Courts of Appeals does play a significant role in shaping executive order use. Confrontation between the president and the courts is not as dramatic as some might expect, where the courts directly overturn an executive order and deem it unconstitutional. Instead, what is found here, is that courts send subtle signals that chip away at bits and pieces of an executive order creating a legal framework for presidents to work within when issuing future orders. Similar to the development of multiple categories of executive orders, this component also moves away from dichotomous coding of written circuit court opinions and develops three decision outcomes for panels - no constraint, moderate constraint, statutory/constitutional constraint. The middle category of moderate constraint identifies an alternative used by panels when they do not want to completely defer to or constrain the president.

Identifying multiple decision outcomes is an important advance for the field of judicial politics because it highlights the importance of a more rigorous analysis of opinions, showing decisions are not all or nothing. This component of the research bridges the gap between 
executive and judicial politics scholars by asking when circuit court panels write opinions with different levels of constraint in cases involving executive orders. The findings show panels comprised of republican appointed judges are more likely to uphold a republican president's executive order and constrain democrat's order. Ideology produces an effect opposite of expectations where increases in ideological distance between the panel and president increases the probability of upholding an executive order and ideologically aligned panels and presidents are more likely to write opinions that constrain the president.

These findings are important for several reasons. First, it shows federal judges are not fully insulated from political pressures. Life tenure can mitigate the influence of politics but partisan pressures still weigh on judges when making decisions. Second, contrary to most arguments, the results show there are constraints placed on the president's use of executive orders. Circuit courts have slowly developed a body of law governing executive orders, serving an important check on the exercise of this presidential tool.

Each of these contributions informs larger questions about presidential powers, the role of institutional relationships, and checks and balances. There is more to the presidential tool box than what is seen on the surface. There is nuance to each tool of the president and researchers should not assume there are limited uses to a single tool. This research shows executive orders have several uses and future research will likely find more. Research should more fully explore the other tools of the president to tease out their nuances. These distinctions are important and allow the president to use executive orders for multiple purposes depending on the level of partisan support in Congress. While Congress rarely serves as a significant check on the president's use of executive orders, the courts do serve as a significant check and constrain how president's use this tool. 
This research moves the field forward and provides a more complete understanding of executive orders. However, research in this area is still limited and scholars should continue to explore this presidential power. There are several avenues of research to build on this study. First, studies traditionally focus on the institutional relationship between Congress and the president to explain when executive orders are used. However, this is a macro-institutional approach to the study of executive orders which does not allow for variation throughout a single session of Congress. Future work should take a micro-institutional approach that identifies statutes cited in the vesting clause of an executive order and then determine if the vote on that legislation has an effect on the type of executive order issued. For instance, do party line votes prompt a different type of executive order than bills passed with bipartisan support?

A second area of inquiry can examine how presidents treat executive orders issued by previous administrations. There is limited research exploring when the president revokes or amends executive orders. Revocations and amendments require more attention and research should examine what type of order is being revoked or amended and what president issued that order.

Finally, the research exploring the judiciary's role in constraining executive orders can be extended in two ways. First, the current study can be replicated for the U.S. District Courts and Supreme Court to provide a comprehensive understanding of the judiciary's treatment of executive orders. Second, the types of executive orders can be integrated into the analysis to determine if certain types are subject to greater scrutiny by the courts.

The American presidency is an evolving office that is shaped by its occupants. While these individuals have many tools available to them, including executive orders, presidents are limited in their ability to wield them. There are institutional constraints that must be taken into 
account. Congress, the judiciary, and the public weigh on the president's decision to issue an executive order and the type or order to issue. Regardless of the limitations executive orders hold and the complexities surrounding the decision to issue one, presidents are likely to continue using them in an attempt to direct the bureaucracy and shape policy unilaterally. 


\section{References}

Adler, David Gary. 2004. "'The Law" Termination of the ABM Treaty and the Political Question Doctrine: Judicial Succor for Presidential Power.” Presidential Studies Quarterly. 34(1): 156-66.

Baird, Vanessa A. 2001. "Building Institutional Legitimacy: The Role of Procedural Justice." Political Research Quarterly. 54(2): 333-54.

Bailey, Michael A., Brian Kamoie, and Forrest Maltzman. 2005. "Signals from the Tenth Justice: The Political Role of the Solicitor General in Supreme Court Decision Making." American Journal of Political Science 49(1): 72-85.

Banks, Christopher P. 1998. "Ideology and Judicial Deference in the DC Circuit." Southeastern Political Review. 26(4): 861-88.

Benesh, Sara C. 2002. The U.S. Courts of Appeals and the Law of Confessions: Perspectives on the History of Justice. New York: LFB Scholarly Publishing.

Black, Ryan C., and Ryan Jones. 2012. The Solicitor General and the United States Supreme Court: Executive Branch Influence and Judicial Decisions. Cambridge: Cambridge University Press.

Black, Ryan C., and Ryan J. Owens. 2011. "Solicitor General Influence and Agenda Setting on the U.S. Supreme Court." Political Research Quarterly. 64(4): 765-78.

Bowie, Jennifer Barnes and Donald R. Songer. 2009. "Assessing the Applicability of Strategic Theory to Explain Decision Making on the Courts of Appeals." Political Research Quarterly. 62(2): 393-407.

Boyd, Christina L. 2010. "Federal District Court Judge Ideology Data."

Boyd, Christina L. 2015. "The Hierarchical Influence of Courts of Appeals on District Courts." The Journal of Legal Studies. 44(1): 113-141.

Caldeira, Gregory A. 1986. "Neither the Purse Nor the Sword: Dynamics of Public Confidence in the Supreme Court." American Political Science Review. 8

Calvert, Randall L., Matthew D. McCubbins, and Barry R. Weingast. 1989. "A Theory of Political Control and Agency Discretion.” American Journal of Political Science. 33(3): 588-611.

Canon, Bradley and Charles Johnson. 1998. Judicial Policies: Implementation and Impact. 2nd ed. Washington DC: CQ Press.

Carp, Robert A. 1972. "The Scope and Function of Intra-Circuit Judicial Communication: A Case Study of the Eighth Circuit." Law and Society Review. 6: 405-26. 
Carrubba, Clifford James. 2009. “A Model of Endogenous Development of Judicial Institutions in Federal and International Systems.” Journal of Politics. 71(1): 55-69.

Caruson, Kiki, and J. Michael Bitzer. 2004. "At the Crossroads of Policymaking: Executive Politics, Administrative Action, and Judicial Deference by the DC Circuit Court of Appeals (1985-1996).” Law \& Policy. 26(3-4): 347-369.

Chiou, Fang-Yi and Lawrence S. Rothenberg. 2014. "The Elusive Search for Presidential Power. American Journal of Political Science. 58(3): 653-68.

Cohen, Jonathan Matthew. 2002. Inside Appellate Courts: The Impact of Court Organization on Judicial Decision Making in the United States Courts of Appeals. Ann Arbor: University of Michigan Press.

Cooper, Phillip J. 2014. By Order of the President: The Use \& Abuse of Executive Direct Action. 2nd eds. Lawrence: University of Kansas Press.

Cross, Frank B. 2007. Decision Making in the U.S. Courts of Appeals. California: Stanford University Press.

Curry, Brett W., Richard L. Pacelle Jr., and Bryan W. Marshall. 2008. “"'An Informal and Limited Alliance": The President and the Supreme Court." Presidential Studies Quarterly. 38(2): 223-47.

Deering, Christopher J., and Forrest Maltzman. 1999. "The Politics of Executive Orders: Legislative Constraints on Presidential Power." Political Research Quarterly. 52(4): 767-83.

Dodds, Graham G. 2013. Take Up Your Pen: Unilateral Presidential Directives in American Politics. Philadelphia: University of Pennsylvania Press.

Ducat, Craig R., and Robert L. Dudley. 1989. "Federal District Judges and Presidential Power During the Postwar Era." The Journal of Politics. 51(1): 98-118.

Durant, Robert F., and Adam L. Warber. 2001. "Networking in the Shadow of Hierarchy: Public Policy, the Administrative Presidency, and the Neoadministrative State." Presidential Studies Quarterly. 31(2): 221-44.

Ellis, Richard J., ed. 2009. Judging Executive Power: Sixteen Supreme Court Cases That Have Shaped the American Presidency. Lanham: Rowman \& Littlefield Publishers, Inc.

Fine, Jeffrey A., and Adam L. Warber. 2012. "Circumventing Adversity: Executive Orders and Divided Government.” Presidential Studies Quarterly. 42(2): 256-274.

Fisher, Louis. 2004. Presidential War Power. Lawrence: University of Kansas Press.

Fleishman, Joel and Arthur Aufses. 1976. "Law and Order: The Problem of Presidential 
Legislation." Law and Contemporary Problems. 40: 1-45.

Galanter, Marc. 1974. "Why the "Haves" Come Out Ahead: Speculations on the Limits of Legal Change." Law and Society Review. 9: 95-160.

George, Tracey E., and Lee Epstein. 1992. "On the Nature of Supreme Court Decision Making." American Political Science Review. 86(2): 323-37.

Giles, Michael W., Virginia A. Hettinger, and Todd C. Peppers 2001. "Picking Federal Judges: A Note on Policy and Partisan Selection Agendas." Political Research Quarterly 54 (September): 623-641.

Gleiber, Dennis W., and Steven A. Shull. 1992. "Presidential Influence in the Policymaking Process.” The Western Political Quarterly. 45(2): 441-67.

Gormley, William T. Jr. 1989. Taming the Bureaucracy: Muscles, Prayers, and Other Strategies. Princeton: Princeton University Press.

Hettinger, Virginia A., Stefanie A. Lindquist, and Wendy L. Martinek. 2006. Judging on a Collegial Court: Influences on Federal Appellate Decision Making. Charlottesville: University of Virginia Press.

Holcombe, Randall G. 1980. “An Empirical Test of the Median Voter Model.” Economic Inquiry. 18(2): 260-74.

Howell, William G. 2003. Power Without Persuasion: The Politics of Direct Presidential Action. Princeton: The Princeton University Press.

Howell, William G. 2005. “Unilateral Powers: A Brief Overview.” Presidential Studies Quarterly. 35(3): 417-39.

Howell, William G. 2013. Thinking About the Presidency. Princeton: Princeton University Press.

Huber, John D., and Charles R. Shipan. 2002. Deliberate Discretion? The Institutional Foundations of Bureaucratic Autonomy. Cambridge: Cambridge University Press.

Humphries, Martha Anne, and Donald R. Songer. 1999. "Law and Politics in Judicial Oversight of Federal Administrative Agencies. ” Journal of Politics. 61: 207-20.

Kastellec, Jonathan P. 2010. "Panel Composition and Voting on the U.S. Courts of Appeals Over Time.” Political Research Quarterly. 64(2): 377-91.

Kastellec, Jonathan P. 2011. "Hierarchical and Collegial Politics on the U.S. Courts of Appeals. Journal of Politics. 73(2): 345-61. 
Kennedy, Joshua B. 2015. “"”'Do This! Do That' and Nothing Will Happen”: Executive Orders and Bureaucratic Responsiveness.” American Politics Research. 43(1): 59-82.

Kernell, Samuel. 2006. Going Public. Washington D.C.: CQ Press

Kuersten, Ashlyn and Donald Songer. 2003. "Presidential Success Through Appointments to the United States Courts of Appeals." American Politics Research. 31(2): 107-37.

King, Kimi Lynn and James Meernik. 1999. "The Supreme Court and the Powers of the Executive: The Adjudication of Foreign Policy." Political Research Quarterly. 52(4): $801-$ 24.

Klein, David E. 2002. Making Law in the United States Courts of Appeals. New York: Cambridge University Press.

Krause, George A., and David B. Cohen. 1997. "Presidential Use of Executive Orders, 19531994.” American Politics Research. 26(4): 458-81.

Krehbiel, Keith. 1998. Pivotal Politics: A Theory of U.S. Lawmaking. Chicago: The University of Chicago Press.

Lee, Emery G. III. 2003. "Policy Windows on the U.S. Courts of Appeals." The Justice System Journal. 24(3): 301-323.

Light, Paul C. 1999. The President's Agenda, 3rd ed. Baltimore: The Johns Hopkins University Press.

Lipsky, Michael. 1980. Street-Level Bureaucracy: Dilemmas of the Individual in Public Services. New York: Russell Sage Foundation.

Lowande, Keneth S. 2014. "The Contemporary Presidency: After the Orders: Presidential Memoranda and Unilateral Action.” Presidential Studies Quarterly. 44(4): 724-41.

Majone, Giandomenico. 2006. "Agenda Setting." in M. Moran, M. Rein, and R. Goodin eds., The Oxford Handbook of Public Policy. Oxford: Oxford University Press.

Major, Mark. 2014. The Unilateral Presidency and the News Media: The Politics of Framing Executive Power. New York: Palgrave MacMillan.

Mayer, Kenneth R. 1999. "Executive Orders and Presidential Power." The Journal of Politics. 61(2): 445-66

Mayer, Kenneth R. 2001. With the Stroke of a Pen: Executive Orders and Presidential Power. Princeton and Oxford: Princeton University Press. 
Mayhew, David R. 2005. Divided We Govern: Party Control, Lawmaking, and Investigations, 1946-2002. New Haven: Yale University Press.

McGuire, Kevin T. 1998. "Explaining Executive Success in the U.S. Supreme Court." Political Research Quarterly. 51: 505-26.

Meier, Ken. 1987. Politics and the Bureaucracy: Policymaking in the Fourth Branch of Government. Monterey: Brooks/Cole.

Moe, Terry M., and William G. Howell. 1999. "Unilateral Action and Presidential Power: A Theory.” Presidential Studies Quarterly. 29(4): 850-73.

Morgan, Ruth P. 1970. The President and Civil Rights: Policy-Making by Executive Order. New York: St. Martin's.

Nathan, Richard P. 1983. The Administrative Presidency. New York: Wiley.

Poole, Keith T., and Howard Rosenthal. 1991. "Patterns of Congressional Voting." American Journal of Political Science. 35(1): 228-78.

Neighbors, William. 1964. "Presidential Legislation by Executive Order." University of Colorado Law Review. 37: 105-118.

Ostrander, Ian, and Joel Sievert. 2012. "The Logic of Presidential Signing Statements." Political Research Quarterly. 66(1): 141-53.

Poole, Keith T., and Howard Rosenthal. 1997. Congress: A Political-Economic History of Roll Call Voting. New York: Oxford University Press.

Rochefort, David A. and Roger W. Cobb. 1994. "Problem Definition: An Emerging Perspective." in D.A. Rochefort and R.W. Cobb, eds., The Politics of Problem Definition. Lawrence: University of Kansas Press.

Rosenberg, Morton. 1981. "Beyond the Limits of Executive Power: Presidential Control of Agency Rulemaking under Executive Order 12,291.” Michigan Law Review. 80(2): 193-247.

Rottinghaus, Brandon and Jason Maier. 2007. "The Power of Decree: Presidential Use of Executive Proclamations, 1977-2005." Political Research Quarterly. 60(2): 338-43.

Rudalevige, Andrew. 2002. Managing the President's Program: Presidential Leadership and Legislative Policy Formulation. Princeton: Princeton University Press.

Rudalevige, Andrew. 2015. "Executive Branch Management and Presidential Unilateralism: Centralization and the Issuance of Executive Orders." Congress \& the Presidency. 42: 342-65 
Sabatier, Paul A. and Hank C. Jenkins-Smith. 1999. "The Advocacy Coalition Framework: An Assessment." in P.A. Sabatier ed., Theories of the Policy Process. Boulder, Colorado: Westveiw Press.

Segal, Jeffrey A. 1990. "Supreme Court Support for the Solicitor General: The Effect of Presidential Appointments.” Political Research Quarterly. 43: 137-52.

Shanley, Robert A. 1983 "Presidential Executive Orders and Environmental Policy." Presidential Studies Quarterly. 13(3): 405-16.

Sheehan, Reginald S. 1990. "Administrative Agencies and the Court: A Reexamination of the Impact of Agency Type on Decisional Outcomes." Western Political Quarterly. 43: 875-85.

Sheehan, Reginald S. 1992. "Federal Agencies and the Supreme Court: An Analysis of Litigation Outcomes, 1953-1988." American Politics Quarterly. 20: 478-500.

Singer, David J., and Melvin Small. 1966. "Formal Alliances, 1815-1939.” Journal of Peace Research. 3: 1-31.

Smith, Joseph L. 2007. "Presidents, Justices, and Deference to Administrative Action.” Journal of Law, Economics, \& Organization. 23(2): 346-64.

Songer, Donald R., and Sue Davis. 1990. "The Impact of Party and Region on Voting Decisions in the United States Courts of Appeals, 1955-1986." Western Political Science Quarterly. 43: 317-34.

Songer, Donald R., and Martha Humphries Ginn. 2002. "Assessing the Impact of Presidential and Home State Influences on Judicial Decisionmaking the United States Courts of Appeals." Political Research Quarterly. 55(2): 299-328.

Songer, Donald R., Martha Humphries Ginn, and Tammy Sarver 2003. "Do Judges Follow the Law When There is Not Fear of Reversal?” Justice System Journal. 24: 137-61.

Songer, Donald R., and Reginald S. Sheehan. 1992. "Who Wins on Appeal? Upperdogs and Underdogs in the United States Courts of Appeals." American Journal of Political Science. 36(1): 235-58.

Songer, Donald R., Reginald S. Sheehan, and Susan Brodie Haire. 1999. "Do the "Haves" Come Out Ahead over Time? Applying Galanter's Framework to Decisions of the U.S. Courts of Appeals, 1925-1988.” Law \& Society Review. 33(4): 811-832.

Songer, Donald R., Reginald S. Sheehan, and Susan Brodie Haire. 2000. Continuity and Change on the United States Courts of Appeals. Ann Arbor: University of Michigan Press.

Staton, Jeffrey K. 2006. "Constitutional Review and the Selective Promotion of Case Results." American Journal of Political Science. 50(1): 98-112. 
Sunstein, Cass R., David Schkade, Lisa M. Ellman, and Andres Sawicki. 2006. Are Judges Political? An Empirical Analysis of the Federal Judiciary. Washington D.C.: Brookings Institution Press.

US Constitution. Article II, sec. 3.

Walker, Jack L., Jr. 1977 "Setting the Agenda in the US Senate: A Theory of Problem Selection.” British Journal of Political Science. 7: 423-45

Warber, Adam L. 2006. Executive Orders and the Modern Presidency. Boulder: Lynne Ripener Publishers.

Warber, Adam L. 2014. "Public Outreach, Executive Orders, and the Unilateral Presidency." Congress and the Presidency. 41: 269-88.

Westerland, Chad, Jeffrey A. Segal, Lee Epstein, Charles M. Cameron, and Scott Comparato. 2010. "Strategic Defiance and Compliance in the U.S. Courts of Appeals." American Journal of Political Science. 54(4): 891-905.

Wigton, Robert C. 1996. "Recent Presidential Experience with Executive Orders." Presidential Studies Quarterly. 26(2): 473-84.

Wildavsky, Aaron. 1975. "The Two Presidencies." in A. Wildavsky ed., Perspectives on the Presidency. Little Brown.

Yates, Jeff. 1999. "Presidential Bureaucratic Power and Supreme Court Justice Voting." Political Behavior. 21(4): 349-66.

Yates, Jeff. 2002. Presidential Prestige and Executive Success in the Supreme Court. New York: State University Press.

Yates, Jeff and Andrew Whitford. 1998. "Presidential Power and the United States Supreme Court.” Political Research Quarterly. 51(2): 539-550.

Zorn, Christopher J.W. 2002. "U.S. Government Litigation Strategies in the Federal Appellate Courts." Political Research Quarterly. 55(1): 145-66.

Zorn, Christopher and Jennifer Barnes Bowie. 2010. "Ideological Influences on Decision Making in the Federal Judicial Hierarchy: An Empirical Assessment." The Journal of Politics. 72(4): 1212-21.

\section{Court Cases}

Association for Women in Science v. Califano, 566 F.2d 339 (DC Cir. 1976)

Burrell v. Martin, 232 F.2d 33 (D.C. Cir. 1955)

Cones v. Shalala, 199 F.3d 512 (D.C. Cir. 2000) 
Dangerfield Island Protective Society v. Babbitt, 40 F.3d 442 (DC Cir. 1994)

Equal Employment Opportunity Commission v. American Telephone and Telegraph Company, 506 F.2d $735\left(3^{\text {rd }}\right.$ Cir. 1974)

Gayer v. Schlesinger, 490 F.2d 740 (D.C. Cir. 1973)

Morris County Trust for Historical Preservation v. Pierce, 714 F.2d 271 ( $3^{\text {rd }}$ Cir. 1983)

Sagebrush Rebellion, Inc. v. Watt, 713 F.2d 525 ( $9^{\text {th }}$ Cir. 1983)

Summers v. Department of Justice, 140 F.3d 1077 (D.C. Cir. 1998)

Todd v. Joint Apprenticeship Committee, 332 F.2d 243 ( $7^{\text {th }}$ Cir. 1964)

United States v. Curtiss-Wright Export, 299 U.S. 304 (1936)

United States v. Nixon, 418 U.S. 683 (1974)

USAA Federal Savings Bank v. McLaughlin, 849 F.2d 1505 (D.C. Cir. 1988)

Youngstown Sheet \& Tube Co. v. Sawyer, 343 U.S. 579 (1952)

\section{Executive Orders}

EO 6166: Organization of Executive Agencies. Franklin D. Roosevelt. June 10, 1933.

EO 10820: Prescribing the Order of Succession of Officers to Act as Secretary of Defense, Secretary of the Army, Secretary of the Navy, and Secretary of the Air Force. Dwight D. Eisenhower. May 18, 1959.

EO 10865: Safeguarding Classified Information Within Industry. Dwight D. Eisenhower.

February 20, 1960.

EO 11201: Inspection of Income, Excess-Profits, Estate, and Gift Tax Returns by the Committee on Government Operations, House of Representatives. Lyndon B. Johnson. March 4, 1965.

EO 11593: Protection and Enhancement of the Cultural Environment. Richard Nixon. May 13, 1971.

EO 11772: Delegating Certain Authority of the President to the Secretary of State. Richard Nixon. March 21, 1974.

EO 12195: President's Commission on United States-Liberian Relations. Jimmy Carter.

February 22, 1980.

EO 12569: Compact of Free Association with the Republic of the Marshall Islands, the

Federated States of Micronesia, and the Republic of Palau. Ronald Reagan. October 16, 1986.

EO 12839: Reduction of 100,000 Federal Positions. William J. Clinton. February 10, 1993.

EO 12958: Classified National Security Information. William J. Clinton. April 17, 1995.

EO 13011: Federal Information Technology. William J. Clinton. July 16, 1996.

EO 13160: Nondiscrimination on the Basis of Race, Sex, Color, National Origin, Disability,

Religion, Age, Sexual Orientation, and Status as a Parent in Federally Conducted

Education and Training. William J. Clinton. June 23, 2000.

EO 13287: Preserve America. George W. Bush. March 3, 2003.

EO 13295: Revised List of Quarantine Communicable Diseases. George W. Bush. April 4, 2003

EO 13310: Blocking Property of the Government of Burma and Prohibiting Certain

Transactions. George W. Bush. July 28, 2003.

EO 13460: Blocking Property of Additional Persons in Connection with the National Emergency with Respect to Syria. George W. Bush. February 13, 2008. 
EO 13490: Ethics Commitments by Executive Branch Personnel. Barack Obama. January 21, 2009.

EO 13491: Ensuring Lawful Interrogations. Barack Obama. January 22, 2009.

EO 13571: Streamlining Service Delivery and Improving Customer Service. Barack Obama. April 27, 2011.

EO 13581: Blocking Property of Transnational Criminal Organizations. Barack Obama. July 24, 2011. 